\title{
7. SITES 346, 347, AND 349
}

\author{
The Shipboard Scientific Party' \\ With Additional Contributions From \\ Svein B. Manum, Universitetet i Oslo, Oslo, Norway \\ and \\ H.-J. Schrader, Der Universität Kiel, Kiel, Germany
}

\section{SITE DATA, SITE 346}

Position: $69^{\circ} 53.35^{\prime} \mathrm{N}$; $08^{\circ} 41.14^{\prime} \mathrm{W}$

Water Depth (from sea level): 732.0 corrected meters (echo sounding)

Bottom Felt at: 741.0 meters (drill pipe)

Penetration: 187.0 meters

Number of Holes: 1

Number of Cores: 20

Total Length of Cored Section: 187.0 meters

Total Core Recovered: 120.4 meters

Percentage of Core Recovery: $64.4 \%$

Oldest Sediment Cored:

Depth below sea floor: 187.0 meters

Nature: Sandy mudstone

Age: Eocene

Measured velocity: $1.83 \mathrm{~km} / \mathrm{sec}$ (Core 14)

Principal Results: Site 346 was located on the Jan Mayen Ridge. Pliocene and Pleistocene sediments extend from the top to a depth of 25.5 meters and consist of terrigenous sandy mud, as well as mud and clay. The middle Miocene sediments consist of sandy mud and biogenic siliceous oozes characterized by a high percentage of sponge spicules. Below the Miocene section is a massive terrigenous sandy mudstone. This unit was quite hard to penetrate, and is almost completely barren of fauna except for arenaceous foraminifera (benthonic), and a few badly preserved calcareous foraminifera.

\section{SITE DATA, SITE 347}

Position: $69^{\circ} 52.31^{\prime} \mathrm{N}$; $08^{\circ} 41.80^{\prime} \mathrm{W}$

Water Depth (from sea level): 745.0 corrected meters (echo sounding)

\footnotetext{
'Manik Talwani, Lamont-Doherty Geological Observatory, Palisades, New York; Gleb B. Udintsev, P.P. Shirshov Institute of Oceanology, Moscow, USSR; Kjell Bjфirklund, Universitetet i Bergen, Bergen, Norway; V.N.D. Caston, British Petroleum Company Ltd., Middlesex, England; Richard W. Faas, Lafayette College, Easton, Pennsylvania; Jan E. van Hinte, Esso Production Research Company, Begles, France; G.N. Kharin, Atlantic Branch of Oceanology Institute, Kaliningrad, USSR; David A. Morris, Phillips Petroleum Company, Bartlesville, Oklahoma; Carla Múller, Geologisch-Paleontologisches Institut der Johann Wolfgang GoetheUniversität, Frankfurt am Main, Germany; Tor H. Nilsen, U.S. Geological Survey, Menlo Park, California; Detlef A. Warnke, California State University, Hayward, California; Stan M. White, University of California at San Diego, La Jolla, California.
}

Bottom Felt at: 762.0 meters (drill pipe)

Penetration: 190.0 meters

Number of Holes: 1

Number of Cores: 4

Total Length of Cored Section: 24.0 meters

Total Core Recovered: 12.15 meters

Percentage of Core Recovery: $50.6 \%$

Oldest Sediment Cored:

Depth below sea floor: 190.0 meters

Nature: Sandy mudstone

Age: Eocene

Measured velocity: $3.082 \mathrm{~km} / \mathrm{sec}$ (Core 3 )

Principal Results: Site 347 was located on the Jan Mayen Ridge about $1 \mathrm{n}$ mi southwest of Site 346, at the edge of the ridge platform. It was hoped that basement would be reached at a shallower depth closer to the edge. The seismic reflection record was unclear near the unconformity at 120 meters, and it was suspected that basement might lie below it. However, even after 190 meters were drilled into Pleistocene and late Eocene sediments, basement was not reached. Since progress was slow and there was no clear indication of when basement might be reached, the hole was terminated.

\section{SITE DATA, SITE 349}

Position: $69^{\circ} 12.41^{\prime} \mathrm{N} ; 08^{\circ} 05.80^{\prime} \mathrm{W}$

Water Depth (from sea level): 915.0 corrected meters (echo sounding)

Bottom Felt at: 928.0 meters (drill pipe)

Penetration: 319.5 meters

Number of Holes: 1

Number of Cores: 13

Total Length of Cored Section: 120.0 meters

Total Core Recovered: 81.2 meters

Percentage of Core Recovery: $67.7 \%$

Oldest Sediment Cored:

Depth below sea floor: 319.5 meters

Nature: Sandy mudstone, mudstone, conglomerate

Age: Late Eocene (Core 13)

Measured velocity: $\cong 2.16 \mathrm{~km} / \mathrm{sec}$ (Core 13)

Principal Results: At this site on the Jan Mayen Ridge, sediments range in age from "glacial" to upper Eocene (as at Sites 346 and 347). The "glacial" sediments consist of 
muds and sandy muds, with scattered inclusions of volcanic ash. The underlying Oligocene sediments also consist of muds and sandy muds, with volcanic ash in the upper part, and glauconite in the upper and lower parts. Below the unconformity lie mudstones, sandy mudstones, conglomerate sandstone, and breccia with an age of upper Eocene. These beds correspond in the reflection profiler records to the strata with prominent easterly dips. Other than arenaceous foraminifera, these sediments are barren of fossils.

\section{BACKGROUND AND OBJECTIVES}

\section{Sites 346 and 347}

Holes at Sites 346 and 347 were among a series of holes designed to investigate the Jan Mayen Ridge. For the sake of this discussion, we exclude Jan Mayen Island and the area immediately adjacent to it, which is probably associated with the Jan Mayen Fracture Zone, and consider the Jan Mayen Ridge southwards from about $70^{\circ} \mathrm{N}$.

Near latitude $70^{\circ} \mathrm{N}$, the Jan Mayen Ridge is relatively broad and flat-topped. The reflection profiler records are not entirely clear, but they indicate relatively flatlying sediments at the top. These beds appear to lie unconformably on top of a sequence, which under the eastern part of the ridge, consists of beds dipping steeply to the east. Acoustic basement also dips to the east, appearing to underlie the unconformity under the western part of the ridge.

Site 346 was designed to reach the acoustic basement and determine its nature and age. When the cores from Site 346 yielded a hard and difficult to penetrate sandstone in which coring times were comparable to coring times in basalt, the question arose whether this sandstone itself represented acoustic basement or whether igneous basement lay further to the west and dipped down at a much steeper angle. If this were the case, it would be impractical to reach igneous basement at Site 346. To settle this point, we moved to Site 347. at the extreme western edge of the Jan Mayen Ridge, and drilled another hole. This hole could determine whether we would still run into the sandstone under the unconformity or whether igneous basement would be reached under the western flank of Jan Mayen Ridge.

\section{BACKGROUND AND OBJECTIVES}

\section{Site 349}

Site 349 was chosen as an additional drill hole on the Jan Mayen Ridge. At this site, the reflection profiler record showed below an unconformity a set of sedimentary strata that dipped to the east. Two possibilities existed; (1) that these beds simply lie stratigraphically above the Eocene sediments encountered at Sites 346 and 347 . These sites were drilled close to the eastern edge of the Jan Mayen Ridge, and (2) that these beds had no relationship with the beds in the earlier holes; in particular, they could lie stratigraphically below them, and they might be Mesozoic in age. In any event it was felt that perhaps the hard to penetrate sandstone at Sites 346 and 347 would be absent at this site. If so, the cores taken would help decipher the sedimentary history and origin of the Jan Mayen Ridge.

\section{OPERATIONS, SITE 346}

\section{Approach to Site 346}

Site 346 was approached from the east on course $276^{\circ}$ at normal speed ( 10 knots, $\left.210 \mathrm{rpm}\right)$ after steaming $162 \mathrm{n} \mathrm{mi}$, including surveying, in $18 \mathrm{hr}, 20 \mathrm{~min}$, at an average speed of 8.8 knots from Site 345 . Weather conditions were generally good with $30-\mathrm{mph}$ winds (average), and an 8-foot swell.

At $0006 \mathrm{Z}$ on 6 September, speed was reduced to 145 $\mathrm{rpm}$. The scheduled site was passed over in order to recognize the real structure of the acoustic basement. At $0346 \mathrm{Z}$, the course was changed to $080^{\circ}$ in order to return to the site (Figure 1). The beacon was dropped at $0433 \mathrm{Z}$, and the ship maneuvered to the site of the beacon drop (Figure 2).

\section{Drilling Operations}

A $13.5-\mathrm{kHz}$ beacon was dropped at $0433 \mathrm{hr}, 6$ September, and after completion of profiling, Glomar Challenger was dynamically positioned and locked onto the beacon. Because of the shallow sea conditions (732 m PDR), particular care was taken to confirm stationkeeping efficiency before running the standard $3 \times$ LSB BHA.

After a sea bed confirmation core at 741 meters, continuous coring was adopted to a depth of 928 meters, for a total penetration of 187 meters. Good progress was achieved to 861.5 meters, with an AROP of 15.4 $\mathrm{m} / \mathrm{hr}$. A marked decrease in AROP to $4.5 \mathrm{~m} / \mathrm{hr}$ was experienced in the remainder of the hole, while coring an unexpectedly dense and compacted material. Overall AROP was $8.25 \mathrm{~m} / \mathrm{hr}$, and 120.4 meters of core were recovered, or $64.4 \%$ (Table 1, Site 346 ).

A decision to abandon further coring and terminate the hole was taken when brief station-keeping problems prohibited rotation and enforced a partial recovery of the BHA closer to the sea bed. In view of the delay, the site was vacated at $1705 \mathrm{hr}, 7$ September.

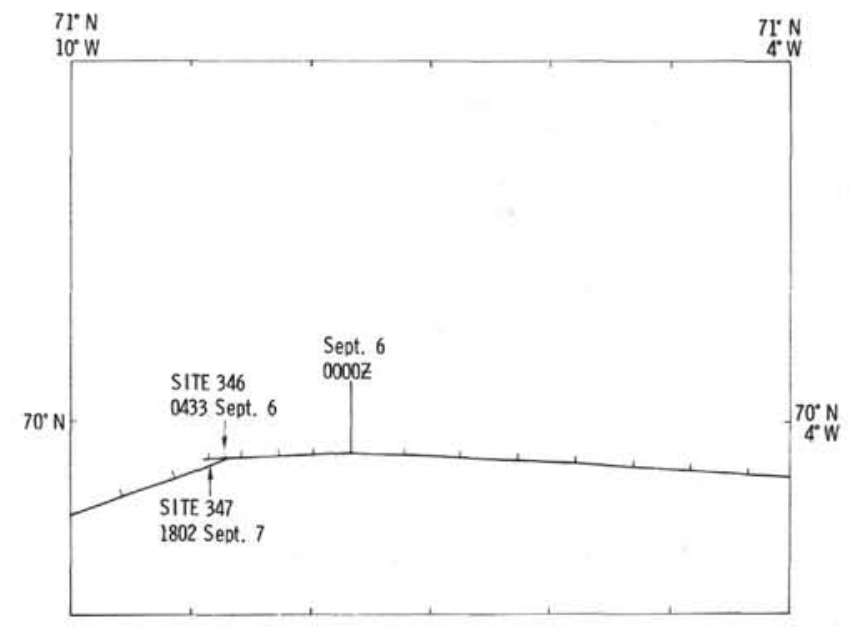

Figure 1. Track chart - Sites 346 and 347. 


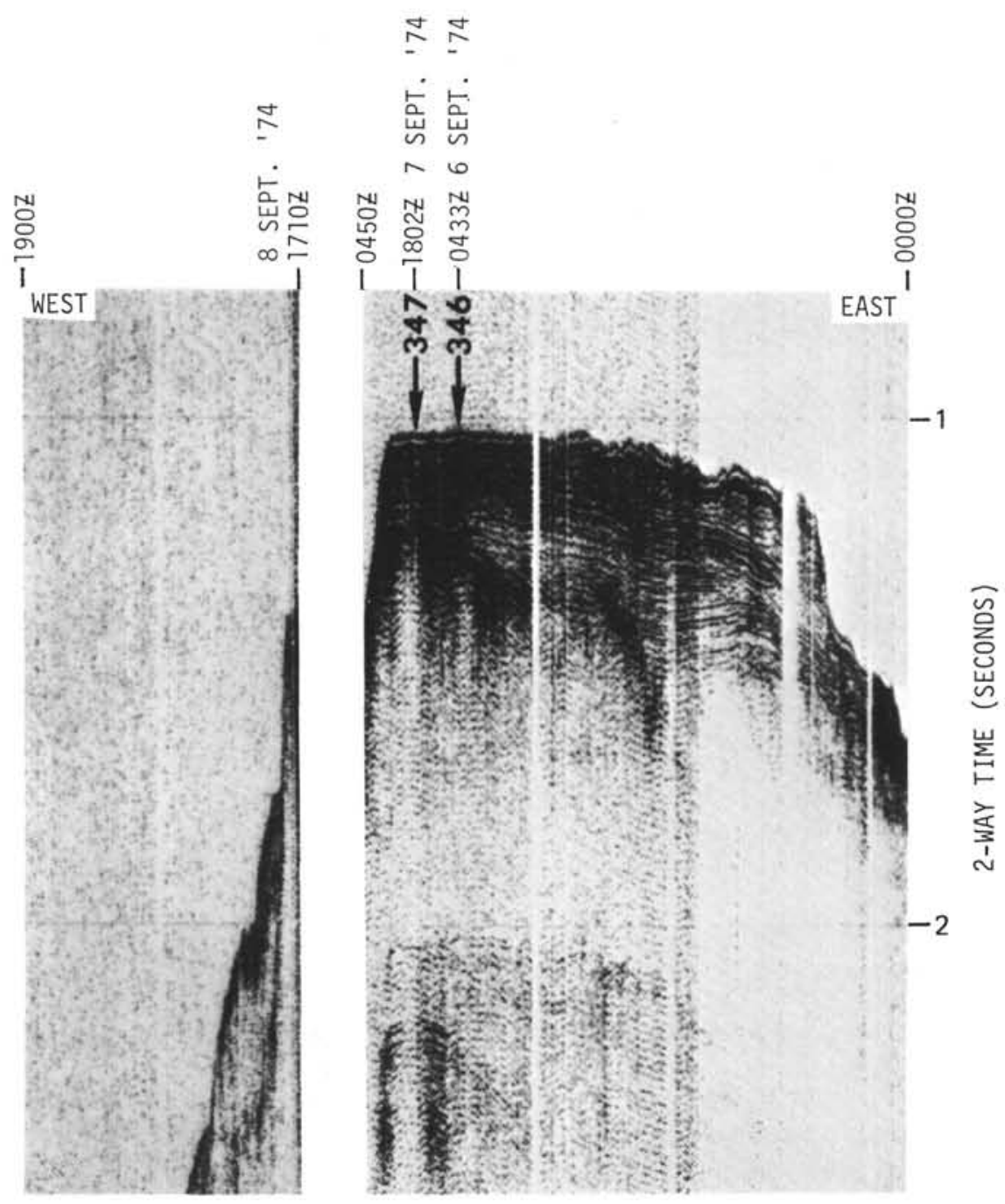

Figure 2. Profiler record - Sites 346 and 347.

The hole remained clean throughout, no hydrocarbon indications were encountered, and the hole was abandoned accordingly. Despite the forecast, a pronounced swell persisted throughout the period on site.

\section{OPERATIONS, SITE 347}

\section{Approach to Site $\mathbf{3 4 7}$}

Since the objective was to get closer to the edge of the platform of the Jan Mayen Ridge, Glomar Challenger steamed due west from Site 346, and crossed the edge of the platform into deeper water (Figure 1). The ship reversed course (to port), and thereby approached the platform again. As soon as the platform edge was reached, the beacon was dropped for Site 347 (Figure 2). Site 347 is about $1 \mathrm{n} \mathrm{mi}$ southwest of Site 346.

\section{Drilling Operations}

A $16-\mathrm{kHz}$ beacon was dropped at $1802 \mathrm{hr}, 7$ September. Enroute the malfunction, which affected position keeping at Site 346, was resolved. There was a gradual improvement in weather conditions, with an improved forecast.

The $3 \times$ LSB BHA was run, and a confirmatory sea bed core taken from 762 meters. The center bit was installed, and the hole was rapidly drilled to 883 meters, where two cores were cut. Drilling resumed to 949 meters, where a final core was recovered. Recoveries from the 24 meters cored was 12.15 meters or $50.6 \%$ (Table 2, Site 347 ). The progress while coring in the lower drilled section was slow due to the compacted and tough nature of the sediments encountered.

The hole remained clean throughout, no hydrocarbon indications were encountered, and the hole was abandoned accordingly. Weather conditions improved during the operations.

\section{OPERATIONS, SITE 349}

\section{Approach to Site 349}

Glomar Challenger approached Site 349 on 13 September, after steaming $104 \mathrm{n} \mathrm{mi}$, including surveying, in $11 \mathrm{hr}, 0.2 \mathrm{~min}$, at an average speed of 9.4 knots 
TABLE 1

Coring Summary, Site 346

\begin{tabular}{|c|c|c|c|c|c|c|c|}
\hline Core & $\begin{array}{c}\text { Date } \\
\text { (September } \\
\text { 1974) }\end{array}$ & Time & $\begin{array}{l}\text { Depth From } \\
\text { Drill Floor } \\
(\mathrm{m})\end{array}$ & $\begin{array}{l}\text { Depth Below } \\
\text { Sea Floor } \\
(\mathrm{m})\end{array}$ & $\begin{array}{c}\text { Cored } \\
(\mathrm{m})\end{array}$ & $\begin{array}{l}\text { Recovered } \\
\text { (m) }\end{array}$ & $\begin{array}{c}\text { Recovery } \\
(\%)\end{array}$ \\
\hline 1 & 6 & 1150 & $741.0-747.5$ & $0-6.5$ & 6.5 & 6.5 & 100 \\
\hline 2 & 6 & 1225 & $747.5-757.0$ & $6.5-16.0$ & 9.5 & 5.7 & 60 \\
\hline 3 & 6 & 1310 & $757.0-766.5$ & $16.0-25.5$ & 9.5 & 9.0 & 94.7 \\
\hline 4 & 6 & 1340 & $766.5-776.0$ & $25.5-35.0$ & 9.5 & 6.5 & 68.4 \\
\hline 5 & 6 & 1425 & $776.0-785.5$ & $35.0-44.5$ & 9.5 & 6.1 & 64.2 \\
\hline 6 & 6 & 1500 & $785.5-795.0$ & $44.5-54.0$ & 9.5 & 6.6 & 69.5 \\
\hline 7 & 6 & 1540 & $795.0-804.5$ & $54.0-63.5$ & 9.5 & 5.3 & 55.8 \\
\hline 8 & 6 & 1610 & $804.5-814.0$ & $63.5-73.0$ & 9.5 & 6.3 & 66.3 \\
\hline 9 & 6 & 1645 & $814.0-823.5$ & $73.0-82.5$ & 9.5 & 6.7 & 70.5 \\
\hline 10 & 6 & 1715 & $823.5-833.0$ & $82.5-92.0$ & 9.5 & 9.0 & 94.7 \\
\hline 11 & 6 & 1745 & $833.0-842.5$ & $92.0-101.5$ & 9.5 & 5.2 & 54.7 \\
\hline 12 & 6 & 1835 & $842.5-852.0$ & $101.5-111.0$ & 9.5 & 6.9 & 72.6 \\
\hline 13 & 6 & 1915 & $852.0-861.5$ & $111.0-120.5$ & 9.5 & 6.2 & 65.3 \\
\hline 14 & 6 & 2035 & $861.5-871.0$ & $120.5-130.0$ & 9.5 & 6.7 & 70.5 \\
\hline 15 & 6 & 2330 & $871.0-880.5$ & $130.0-139.5$ & 9.5 & 6.4 & 67.4 \\
\hline 16 & 7 & 0255 & $880.5-890.0$ & $139.5-149.0$ & 9.5 & 2.9 & 31.0 \\
\hline 17 & 7 & 0520 & $890.0-899.5$ & $149.0-158.5$ & 9.5 & 4.5 & 47.0 \\
\hline 18 & 7 & 0810 & $899.5-909.0$ & $158.5-168.0$ & 9.5 & 4.7 & 49.0 \\
\hline 19 & 7 & 1040 & $909.0-918.5$ & $168.0-177.5$ & 9.5 & 6.0 & 63.1 \\
\hline 20 & 7 & 1310 & $918.5-928.0$ & $177.5-187.0$ & 9.5 & 3.2 & 34.0 \\
\hline Total & & & 928.0 & 187.0 & 187.0 & 120.4 & 64.4 \\
\hline
\end{tabular}

TABLE 2

Coring Summary, Site 347

\begin{tabular}{cccccccc}
\hline & $\begin{array}{c}\text { Date } \\
\left(\begin{array}{c}\text { September } \\
\text { Core }\end{array}\right.\end{array}$ & Time & $\begin{array}{c}\text { Depth From } \\
\text { Drill Floor } \\
(\mathrm{m})\end{array}$ & $\begin{array}{c}\text { Depth Below } \\
\text { Sea Floor } \\
(\mathrm{m})\end{array}$ & $\begin{array}{c}\text { Cored } \\
(\mathrm{m})\end{array}$ & $\begin{array}{c}\text { Recovered } \\
(\mathrm{m})\end{array}$ & $\begin{array}{c}\text { Recovery } \\
(\%)\end{array}$ \\
\hline 1 & 7 & 2330 & $762.0-766.5$ & $0-4.5$ & 4.5 & 3.5 & 100 \\
Drilled & 8 & 0130 & $766.5-883.0$ & $4.5-121.0$ & & & \\
2 & 8 & 0350 & $883.0-890.0$ & $121.0-128.0$ & 7.0 & 3.0 & 42.8 \\
3 & 8 & 0645 & $890.0-899.5$ & $128.0-137.5$ & 9.5 & 3.5 & 37 \\
Drilled & 8 & 1240 & $889.5-949.0$ & $137.5-187.0$ & & & \\
4 & 8 & 1500 & $949.0-952.0$ & $187.0-190.0$ & 3.0 & 2.15 & 72 \\
Total & & & 952.0 & 190.0 & 24.0 & 12.15 & 50.6 \\
\hline
\end{tabular}

from Site 348. At 0845Z, 13 September, speed was reduced to 6 knots $(145 \mathrm{rpm})$, and the beacon was dropped at $0950 \mathrm{Z}$. The ship continued on the same course and speed until 1010Z (Figure 3 ) at which time she maneuvered to return to the site of the beacon drop (Figure 4).

\section{Drilling Operations}

After confirming sea bed at 928 meters with an initial core, a core/wash program, averaging $40 \mathrm{~m} / \mathrm{hr}$, was applied to 91.5 meters, at which point continuous coring began and continued to 158 meters. The center bit was employed in the more consolidated and harder sediments, and drilling and control coring program was adopted with good all-round results from 158 meters to total depth at 1247.5 meters (319.5 m BSB).

From the total of 120 meters cored, 81.2 meters were recovered, or $67.7 \%$ (Table 3). The overall AROP was $14.4 \mathrm{~m} / \mathrm{hr}$, and there was a general improvement in washing and drilling rate compared with similar sections at earlier sites. Two operational delays were caused when rotation was stopped due to off-hole displacement exceeding $3 \%$ water depth, and when a loss of hydraulic prime mover electrical power occurred.
The hole remained clean throughout, no hydrocarbon indications were encountered, and the hole was abandoned accordingly.

\section{LITHOLOGY, SITE 346}

The sedimentary sequence cored at Site 346 totaled 187 meters. The sequence can conveniently be divided into three informal units. The depth, core numbers, age, and significant characteristics are summarized in Table 4 and Figure 5.

\section{Unit Descriptions}

\section{Unit 1 (Quaternary to Miocene, $46.7 \mathrm{~m}$ thick)}

This unit is subdivided into two subunits.

Subunit 1A consists of massive terrigenous sandy mud and mud, yellowish-brown in its upper part and gray, and olive-gray in its lower part. It is generally soft, but is locally incoherent where drilling deformation, which is generally moderate to intense, has strongly affected the sediment.

Subunit 1B consists of interstratified siliceous-rich glauconitic sandy mud, terrigenous sandy mud, volcanic-rich sandy mud, volcanic ash, glauconitic 


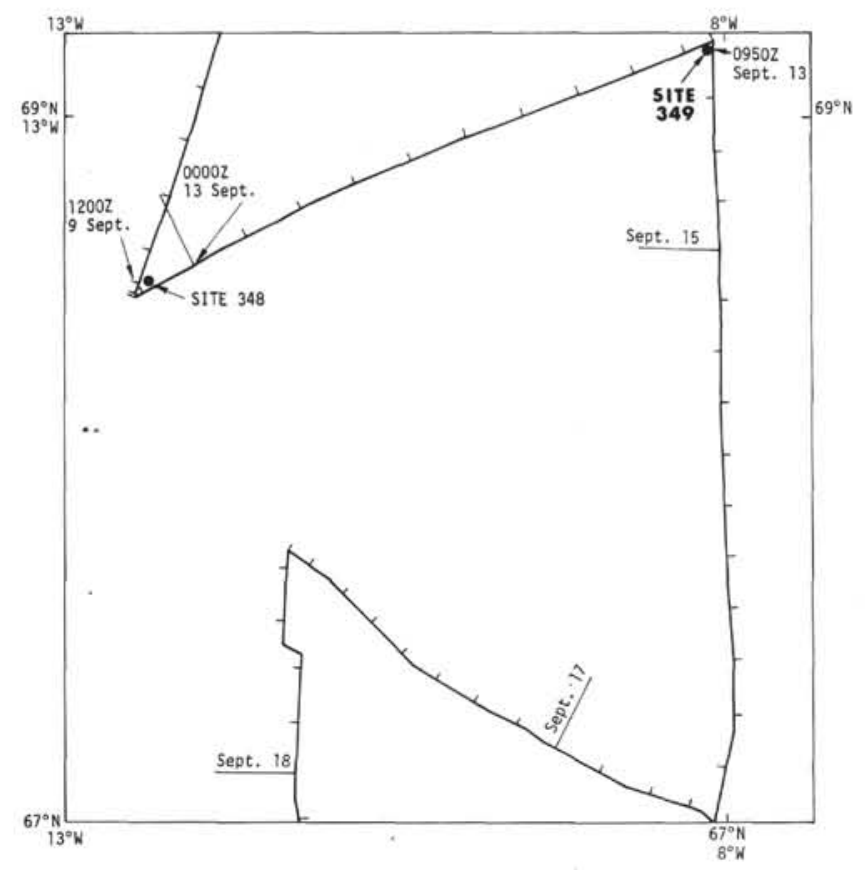

Figure 3. Track chart - Site 349

sandy mud and sand, and transitional siliceous mud and sandy mud. Individual units range from about $5 \mathrm{~cm}$ to more than 1 meter in thickness, and contain no visible internal sedimentary structures. Colors include various shades of green, gray, and brown. The subunit is generally soft to stiff, but is locally incoherent where drilling deformation, which is generally moderate to intense, has strongly affected the sediment.

Two prominent volcanic ash units were noted. The uppermost was located in Sample 4-5, 124-130 cm, and the lowermost was located in Sample 5-2, 140-142 cm. In addition to these two discrete units, volcanic ash comprises a significant component in Subunit 1B.

Glauconitic sandy muds and sands are common, and glauconite is also a common constituent within Subunit 1B. Four prominent glauconitic sands, as much as 30 $\mathrm{cm}$ thick, were noted in Samples 5-1, $119 \mathrm{~cm} ; 5-2,20$ $\mathrm{cm}, 65 \mathrm{~cm}$; and $5-3,147 \mathrm{~cm}$.

Transitional siliceous muds and sandy muds are present in Core 5, and consist of 5\%-30\% sand, $20 \%$ silt, and $50 \%-70 \%$ clay. These units are as thick as 1.5 meters, typically do not contain internal stratification or sedimentary structures, and contain $10 \%-20 \%$ sponge spicules.

Terrigenous sandy muds are as thick as 0.5 meters; they are generally massive and contain no internal sedimentary structures.

\section{Unit 2 (middle Miocene to lower Miocene or middle-upper Oligocene, $82.1 \mathrm{~m}$ thick)}

This unit consists of four subunits.

Subunit $2 \mathrm{~A}$ consists of massive transitional siliceous sandy muds and muds that contain $7 \%-20 \%$ sponge spicules and two thin volcanic ash units. It is green to gray, and soft to firm, but locally incoherent where drilling deformation, which is generally moderate to not present, has strongly affected the sediment. Mottling is locally intense, but is generally not present or is moderately developed. Small lithic fragments are reported from Core 6.

Subunit $2 \mathrm{~B}$ consists of terrigenous mud and sandy mud. It is generally massive to poorly stratified, olivegray and grayish-olive-green, and soft to firm throughout except for irregularly distributed stiff thin units. Drilling deformation is slight to none throughout the unit. It is locally mottled, and contains very small amount of volcanic ash.

Subunit $2 \mathrm{C}$ is similar to Subunit $2 \mathrm{~A}$, consisting of transitional siliceous mud and minor sandy mud. It is olive-black, olive-gray, and dark greenish-gray. It locally contains pebbles of mudstone and possibly volcanic rocks and contains a single thin volcanic ash layer in Sample 11-3, $90 \mathrm{~cm}$.

Subunit 2D is similar to Subunit 2B and consists of terrigenous mud. It is olive-gray and dark greenish-gray and contains scattered volcanic ash (?) and mudstone pebbles.

\section{Unit 3 (Oligocene to upper Eocene, $66.2 \mathrm{~m}$ minimum thickness)}

Unit 3 consists primarily of massive, extensively bioturbated terrigenous sandy mudstone that locally grades into sandstone and mudstone. It is generally unstratified, and contains no visible sedimentary structures. It is hard and lithified; no coring deformation was noted. It ranges in color from olive and dark greenish-gray to medium and medium dark gray. A single thin ash lamination is present in the upper part of the unit. The unit is locally calcareous, and two calcareous sandstone units have been recognized, in Samples $15-3,15 \mathrm{~cm}$ and $20, \mathrm{CC}$. In its lower part, it contains increasing amounts of thin, graded, finegrained sandstone to mudstone units.

The massive sandy mudstone contains scattered, fine, generally rounded clasts of quartz, chert, siltstone, and possibly basalt. Trace fossils are generally unidentifiable, although worm tubes are abundant throughout the unit.

The thin graded units in the lower part of Unit 3 consist of a lower massive, to very thinly parallel-stratified, very fine to fine-grained sandstone or siltstone that grades upward into massive mudstone or claystone. The basal sandstone of the turbidites is characteristically light colored, rests with minor unconformity on the underlying sandy mudstone, and may be calcareous or quartz rich.

\section{Interpretations}

Most of the sediments at Site 346 are terrigenous sandy muds and mudstones with minor biogenic components. The Plio-Pleistocene sandy mud and mud of Subunit $1 \mathrm{~A}$ are presumably of glacial-marine origin, but include minor contributions from pelagic organisms such as calcareous nannoplankton and foraminifera, bottom-dwelling organisms such as sponges, diagenetic mineral alteration products such as glauconite, and volcanic ash. Local mottling of the sediments suggests the presence of bioturbation. In comparison to other nearby sites, the sequence has 


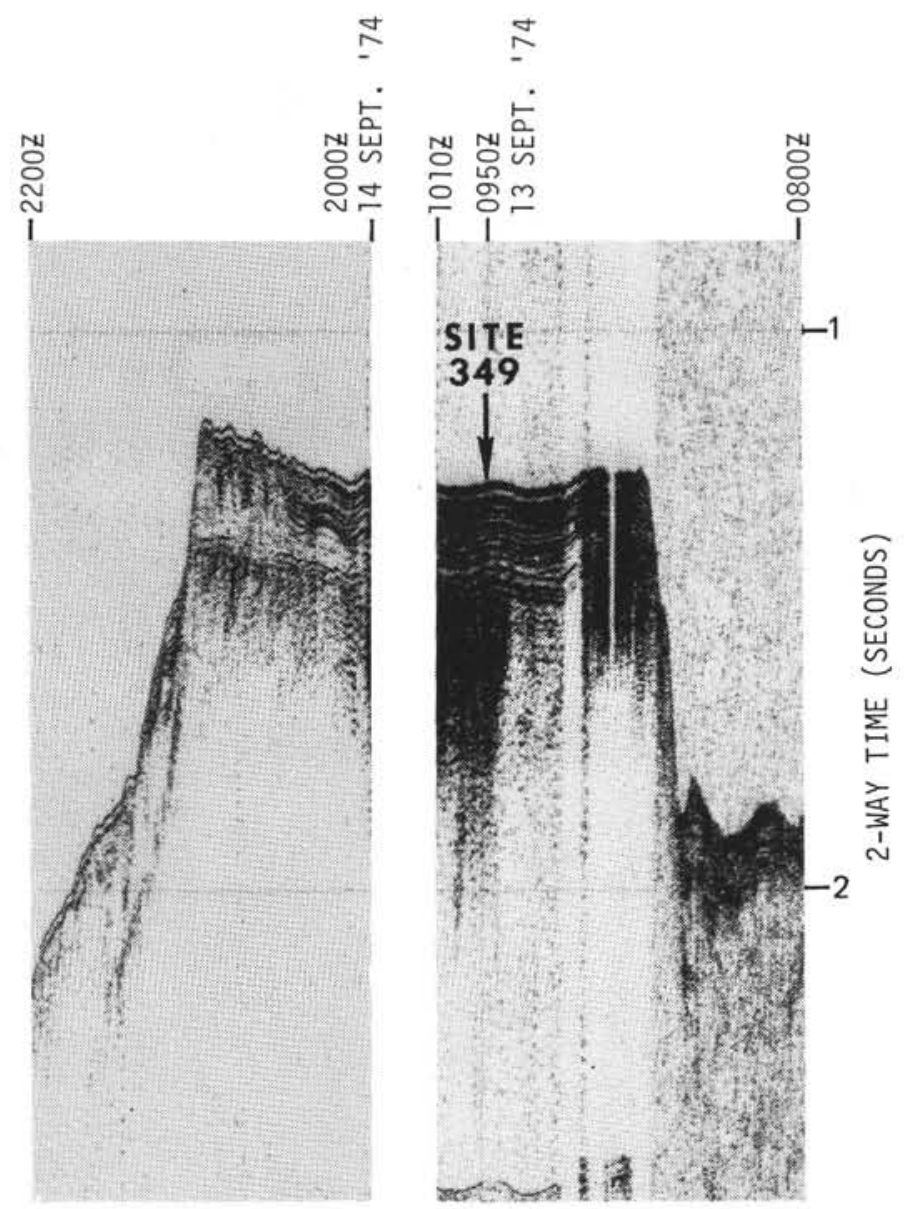

Figure 4. Profiler record - Site 349.

TABLE 3

Coring Summary, Site 349

\begin{tabular}{|c|c|c|c|c|c|c|c|}
\hline Core & $\begin{array}{c}\text { Date } \\
\text { (September } \\
\text { 1974) }\end{array}$ & Time & $\begin{array}{l}\text { Depth From } \\
\text { Drill Floor } \\
\text { (m) }\end{array}$ & $\begin{array}{l}\text { Deptn Below } \\
\text { Sea Floor } \\
(\mathrm{m})\end{array}$ & $\begin{array}{l}\text { Cored } \\
(\mathrm{m})\end{array}$ & $\begin{array}{l}\text { Recovered } \\
\text { (m) }\end{array}$ & $\begin{array}{c}\text { Recovery } \\
\text { (\%) }\end{array}$ \\
\hline 1 & 13 & 1750 & $928.0-934.0$ & $0-6.0$ & 6.0 & 6.0 & 100 \\
\hline Washed & & & $934.0-981.5$ & $6.0-53.5$ & & & \\
\hline 2 & 13 & 1930 & $981.5-991.0$ & $53.5-63.0$ & 9.5 & 9.5 & 100 \\
\hline Washed & & & $991.0-1019.5$ & $63.0-91.5$ & & & \\
\hline 3 & 13 & 2015 & $1019.5-1029.0$ & $91.5-101.0$ & 9.5 & 2.7 & 28.4 \\
\hline 4 & 13 & 2050 & $1029.0-1038.5$ & $101.0-110.5$ & 9.5 & 1.0 & 10.5 \\
\hline 5 & 13 & 2235 & $1038.5-1048.0$ & $110.5-120.0$ & 9.5 & 9.5 & 100 \\
\hline & 14 & 0020 & $1048.0-1057.5$ & $120.0-129.5$ & 9.5 & 8.1 & 85.3 \\
\hline 7 & 14 & 0205 & $1057.5-1067.0$ & $129.5-139.0$ & 9.5 & 6.4 & 67.4 \\
\hline 8 & 14 & 0310 & $1067.0-1076.5$ & $139.0-148.5$ & 9.5 & 1.3 & 13.7 \\
\hline 9 & 14 & 0515 & $1076.5-1086.0$ & $148.5-158.0$ & 9.5 & 5.2 & 54.7 \\
\hline Drill & & & $1086.0-1114.5$ & $158.0-186.5$ & & & \\
\hline 10 & 14 & 0755 & $1114.5-1124.0$ & $186.5-196.0$ & 9.5 & 9.0 & 94.7 \\
\hline Drill & & & $1124.0-1152.5$ & $196.0-224.5$ & & & \\
\hline 11 & 14 & 1005 & $1152.5-1162.0$ & $224.5-234.0$ & 9.5 & 7.0 & 73.7 \\
\hline Drill & & & $1162.0-1190.5$ & $234.0-262.5$ & & & \\
\hline 12 & 14 & 1255 & $1190.5-1200.0$ & $262.5-272.0$ & 9.5 & 6.8 & 71.6 \\
\hline Drill & & & $1200.0-1238.0$ & $272.0-310.0$ & & & \\
\hline 13 & 14 & 1730 & $1238.0-1247.5$ & $310.0-319.5$ & 9.5 & 8.7 & 91.6 \\
\hline Total & & & 1247.5 & 319.5 & 120.0 & 81.2 & 67.7 \\
\hline
\end{tabular}

limited thickness and fine grain size, i.e., relatively few pebbles were observed in Subunit 1A.
Subunit 1B represents a variety of sediment types, sedimentary processes, and sedimentary environments. 
TABLE 4

Lithologic Summary, Site 346

\begin{tabular}{|c|c|c|c|}
\hline Unit & $\begin{array}{l}\text { Depth }(m) \\
\text { and Core } \\
\text { Numbers }\end{array}$ & Age & Significant Characteristics \\
\hline $1 \mathrm{~A}$ & $\begin{array}{l}0-32.3 \\
(1-1 \text { to } 4-5 \\
80) 32.3 \mathrm{~m} \\
\text { thickness }\end{array}$ & $\begin{array}{l}\text { Pleistocene } \\
\text { Pliocene }\end{array}$ & $\begin{array}{l}\text { Terrigenous sandy mud and } \\
\text { mud with intermixed sandy } \\
\text { muds and muds in lower } \\
1.9 \mathrm{~m} \text { of unit, of the sedi- } \\
\text { ments recovered, } 61 \% \text { is } \\
\text { sandy mud, } 32 \% \text { mud, and } \\
7 \% \text { intermixed sandy mud } \\
\text { and mud. The texture con- } \\
\text { sists of } 5 \%-18 \% \text { sand, } 10 \% \text { - } \\
40 \% \text { silt, and } 45 \%-75 \% \text { clay }\end{array}$ \\
\hline 1B & $\begin{array}{l}32.3-39.7 \\
(4-5,80 \text { to } \\
5-4,18) \\
7.4 \mathrm{~m} \\
\text { thickness }\end{array}$ & Middle & $\begin{array}{l}42 \% \text { transitional siliceous- } \\
\text { rich glauconitic sandy mud, } \\
\text { and volcanic ash, } 10 \% \\
\text { glauconitic sandy mud and } \\
\text { sand, and } 8 \% \text { transitional } \\
\text { siliceous mud and sandy } \\
\text { mud; transitional siliceous- } \\
\text { rich glauconitic sandy muds } \\
\text { occur in Core } 5 \text {, Sections } 1 \\
\text { and } 3\end{array}$ \\
\hline $2 \mathrm{~A}$ & $\begin{array}{l}39.7-63.5 \\
(5-4,18 \text { to } \\
7, \mathrm{CC}) \\
23.8 \mathrm{~m} \\
\text { thickness }\end{array}$ & $\begin{array}{l}\text { Middle } \\
\text { Miocene }\end{array}$ & $\begin{array}{l}\text { Transitional siliceous sandy } \\
\text { muds and muds texture } \\
\text { varies from 5\%-30\% sand, } \\
15 \%-30 \% \text { silt, and } 50 \%-55 \% \\
\text { clay }\end{array}$ \\
\hline $2 \mathrm{~B}$ & $\begin{array}{l}63.5-75.7 \\
(8-1 \text { to } 9.2 \\
50) 12.2 \mathrm{~m} \\
\text { thickness }\end{array}$ & $\begin{array}{l}\text { Middle } \\
\text { Miocene }\end{array}$ & $\begin{array}{l}\text { Terrigenous mud with sandy } \\
\text { mud in Core } 9 \text {, Section } 1 \\
\text { and } 0.1 \mathrm{~m} \text { volcanic ash unit } \\
\text { in Core } 8 \text {, Section } 5 \text {; tex- } \\
\text { ture of the mud is com- } \\
\text { prised of } 15 \%-20 \% \text { sand, } 30 \% \\
40 \% \text { silt and } 30 \%-55 \% \text { clay }\end{array}$ \\
\hline $2 \mathrm{C}$ & $\begin{array}{l}75.7-101.5 \\
(9-2,50 \text { to } \\
11, \mathrm{CC}) \\
25.8 \mathrm{~m} \\
\text { thickness }\end{array}$ & $\begin{array}{l}\text { Middle } \\
\text { Miocene }\end{array}$ & $\begin{array}{l}\text { Transitional siliceous mud } \\
\text { and minor sandy mud with } \\
\text { a texture comprised of } 3 \% \\
15 \% \text { sand, } 17 \%-60 \% \text { silt, } \\
35 \%-80 \% \text { clay }\end{array}$ \\
\hline $2 \mathrm{D}$ & $\begin{array}{l}101.5-121.8 \\
(12-1 \text { to } \\
14-2,133) \\
20.3 \mathrm{~m} \\
\text { thickness }\end{array}$ & $\begin{array}{l}\text { Oligocene } \\
\text { (?) }\end{array}$ & $\begin{array}{l}\text { Terrigenous mud with a tex- } \\
\text { ture comprised of } 5 \%-10 \% \\
\text { sand, } 60 \%-70 \% \text { silt, } 20 \% \\
45 \% \text { clay }\end{array}$ \\
\hline 3 & $\begin{array}{l}121.8-187.0 \\
(14-2,133 \text { to } \\
20, \mathrm{CC}) \\
66.2 \mathrm{~m} \\
\text { minimum } \\
\text { thickness }\end{array}$ & Eocene (?) & $\begin{array}{l}\text { Massive terrigenous sandy } \\
\text { and pebbly mudstone that is } \\
\text { interrupted by minor } \\
\text { amounts of mudstone and } \\
\text { calcareous sandstone } \\
\text { arranged into graded beds } \\
\text { less than } 30 \mathrm{~cm} \text { thick and } \\
\text { rare volcanic ash laminae; } \\
\text { generally lithified with no } \\
\text { coring deformation; exten- } \\
\text { sively bioturbated through- } \\
\text { out except for graded turbi- } \\
\text { dite units, which are lamina- } \\
\text { ted to very thinly stratified; } \\
\text { abundant scattered pebbles } \\
\text { of quartz, chert, siltstone, } \\
\text { and basalt (?) less than } 0.5 \\
\text { cm; worm tubes scattered } \\
\text { throughout; locally calcare- } \\
\text { ous and very hard }\end{array}$ \\
\hline
\end{tabular}

${ }^{\mathrm{a}}$ Core numbers in parentheses.
Glauconitic sediments may represent either a hiatus in sedimentation, or an unconformity, inasmuch as this unit appears to separate Quaternary (Plio-Pleistocene) sediments above, from Miocene sediments below. Subunit 1B contains sandy mud in its upper part that is somewhat similar to Subunit 1A, and in its lower part transitional siliceous mud that is somewhat similar to Subunit 2A.

Subunits $2 \mathrm{~A}$ and $2 \mathrm{C}$ are generally similar to Subunits $2 \mathrm{~B}$ and $2 \mathrm{D}$, being differentiated primarily by the presence of larger numbers of sponge spicules in Subunits $2 \mathrm{~A}$ and $2 \mathrm{C}$. They grade vertically into one another, and are not substantially different in color, composition of clastic components, or sedimentologic characteristics. The abundance of sponge remains may be related to cold marine waters, a suitable growth environment, or conditions that were unattractive to other fauna. The sediments are locally intensely mottled, indicating abundant organic reworking and probably accumulated in a relatively shallow environment.

Unit 3 is generally similar to Subunit $2 B$, but does not contain sponge spicules or other biogenic material. It is lithified, and the boundary between it and Subunit 2B may represent an unconformity. The increasing abundance of graded beds downward within Unit 3 may suggest deposition at deeper marine environments.

\section{LITHOLOGY, SITE 347}

Because Site 347 was located only a few kilometers from Site 346, and the drilling objective was to reach basement beneath the sedimentary sequence as quickly as possible, little coring was done in the sedimentary sequence. It may generally be assumed that the sequence at Site 347 is similar to Site 346 , since both sites lie adjacent to one another on the top of the Jan Mayen Plateau.

The sedimentary sequence at Site 347 can be divided, on the basis of the limited number and wide spacing of cores, into two units. The age, depth, colors, significant characteristics, and core numbers for each unit are summarized in Table 5, and Figure 5.

\section{Unit Descriptions}

\section{Unit 1}

Unit 1 consists of yellowish-brown mud in its upper part (Core 1, Section 1 and Core 1, Section 2), and transitional nannofossil ooze in its lower part (Core 1, Section 3 and Sample 1, CC). It was cored from the ocean floor to a depth of 6.5 meters. The sediments are soft to incoherent, drilling deformation is pervasive, and much of the sequence is soupy and intensely deformed. No sedimentary structures or stratification were noted, except for a concentration of sand and pebbles in Sample $1-1,100 \mathrm{~cm}$. Lithic clasts and biogenic debris are generally scattered throughout the unit, but are also locally concentrated at a few levels. Lithic clasts less than $6 \mathrm{~mm}$ in diameter include brown siltstone and various other lithologies. Biogenic debris includes sponge spicules, foraminifera, lamellobrachs, and a single thin gastropod shell thought to be of the order Stenoglossa. The transitional nannofossil ooze includes local concentrations of foraminiferal tests. 
TABLE 5

Lithologic Summary, Site 347

\begin{tabular}{|c|c|c|c|}
\hline Unit & $\begin{array}{l}\text { Depth }(\mathrm{m}) \\
\text { and Core } \\
\text { Numbers }\end{array}$ & Age & Significant Characteristics \\
\hline 1 & $\begin{array}{l}0-6.5 \\
\text { (1) }\end{array}$ & Quaternary & $\begin{array}{l}\text { Terrigenous mud in upper } \\
\text { part and transitional nanno- } \\
\text { fossil ooze in lower part; soft } \\
\text { to incoherent soupy to in- } \\
\text { tense drilling deformation; } \\
\text { massive unstratified and } \\
\text { without sedimentary struc- } \\
\text { tures; abundant scattered } \\
\text { pebbles, foraminiferal tests, } \\
\text { and other biogenic debris; } \\
\text { transitional nannofossil ooze } \\
\text { contains } 30 \%-50 \% \text { nanno- } \\
\text { fossils }\end{array}$ \\
\hline
\end{tabular}

Note: No coring was done between $6.5 \mathrm{~m}$ and $121.0 \mathrm{~m}$, and between 137.5 and $187.0 \mathrm{~m}$

$2 \quad \begin{array}{ll}121.0-137.5 ; \\ 187.0-190.0\end{array}$ (2-3 to 4$)$
Terrigenous mudstone and sandy mudstone with minor amounts of lithic-rich sandstone, claystone, and volcanic ash; lithified throughout, no core deformation; massive with no currentformed sedimentary structures; extensively bioturbated; almost no biogenic material noted in smear slides

${ }^{\mathrm{a}}$ Core numbers in parentheses.

\section{Unit 2}

Unit 2 consists primarily of massive terrigenous mudstone and sandy mudstone, but includes subordinate amounts of sandstone, claystone, and minor amounts of volcanic ash. It is extensively bioturbated, and contains scattered, generally well-rounded, fine pebbles. The unit is lithified and generally undeformed by drilling. No current-formed sedimentary structures were recognized. The sandy mudstone contains pyrite nodules in Sections 2-2, 3-1, and 3-3, and calcite veinlets in Core 2, Section 2. Volcanic ash units from 1$10 \mathrm{~cm}$ in thickness were noted in Samples 2-1, $117 \mathrm{~cm}$; 3-3, $35 \mathrm{~cm} ; 3-3,101 \mathrm{~cm}$; and 3-3, $145 \mathrm{~cm}$.

Mudstone and sandy mudstone represent more than $90 \%$ of the thickness of the unit, which appears to be almost wholly terrigenous, containing only trace amounts of sponge spicules. A variable percentage of lithic fragments that may include devitrified volcanic glass, chert, indurated mudstone and claystone clasts, and altered aphanitic volcanic clasts is present. Sample 4, CC contained $45 \%$ carbonate thought to be of detrital origin, as well as schist and metaquartz fragments. Larger pebbles in the mudstone/sandy mudstone were tentatively identified as siltstone, quartzite, chert, and possibly pyrite, although the latter is more probably authigenic in origin. Although extensively and thoroughly bioturbated, the mudstone/sandy mudstone contained no identifiable trace fossils.

Poorly sorted terrigenous lithic-rich sandstone and claystone are minor constituents of Unit 2 and are generally irregularly intermixed in the unit rather than organized into discrete strata. A single claystone unit is present in Sample 4-1, $105 \mathrm{~cm}$; it is massive and occurs as broken fragments; it may possibly represent the upper part of a turbidite unit of which the lower sandstone is missing.

The volcanic ash units are fine grained and appear to consist primarily of devitrified volcanic glass with minor amounts of quartz, feldspar, mica, and zeolites.

\section{Interpretations}

As with adjacent Site 346 on the Jan Mayen Plateau, the lack of sedimentary structures, stratification, and cyclic sedimentation in the sedimentary sequence at Site 347 makes interpretation of depositional processed and environments difficult. In addition, only four partly filled cores within the 190 meters of sediments and sedimentary rocks were recovered. The reader is referred to the more inclusive descriptions of similar sedimentary units and conclusions regarding the probably similar sedimentary history contained in the lithologic summary for adjacent Site 346.

Unit 1 appears to represent Quaternary sedimentation on top of the Jan Mayen Plateau. The muds may represent glacial-marine ice-rafted sedimentation or glacial-marine sediments reworked by current activity or deposit-feeding organisms on top of the plateau. The underlying transitional biogenic siliceous oozes of Unit 1 may represent hemipelagic sedimentation between episodes of glacial-marine sedimentation. The reasons for the presence of the transitional biogenic calcareous nannofossil ooze in the upper few meters of this site, as opposed to its absence at Site 346 , is not known.

Unit 2 consists of an apparently thick sequence of massive mudstones and sandy mudstones that are very comparable to similar strata in Unit 3 at Site 346 . The extensive bioturbation of Unit 3 may suggest a slow sedimentation rate, and the possible presence of a turbidite unit may indicate deposition in relatively deep water. However, the source and direction of transport of the sands and fine rounded lithic pebbles are not known.

\section{LITHOLOGY, SITE 349}

The sedimentary sequence at Site 349 was penetrated to a subbottom depth of 319.5 meters. Because of discontinuous coring, the thickness of sedimentary units and boundaries between sedimentary units are poorly known and can only be approximated.

The sedimentary sequence can conveniently be divided into three stratigraphic units. The depth, core numbers, age, color, and significant characteristics of each unit are summarized in Table 6 and Figure 6.

\section{Unit Descriptions}

\section{Unit 1 (Pleistocene, 0-59.3 m)}

Unit 1 consists of massive, intensely deformed, soft, locally mottled sandy mud and mud with scattered inclusions of volcanic ash that do not form distinctive layers. It is primarily yellowish-brown, but includes olive-gray and dark gray colors. Quartz, feldspar, clay minerals, glauconite, and volcanic glass comprise most of the unit; minor amounts of other detrital minerals 


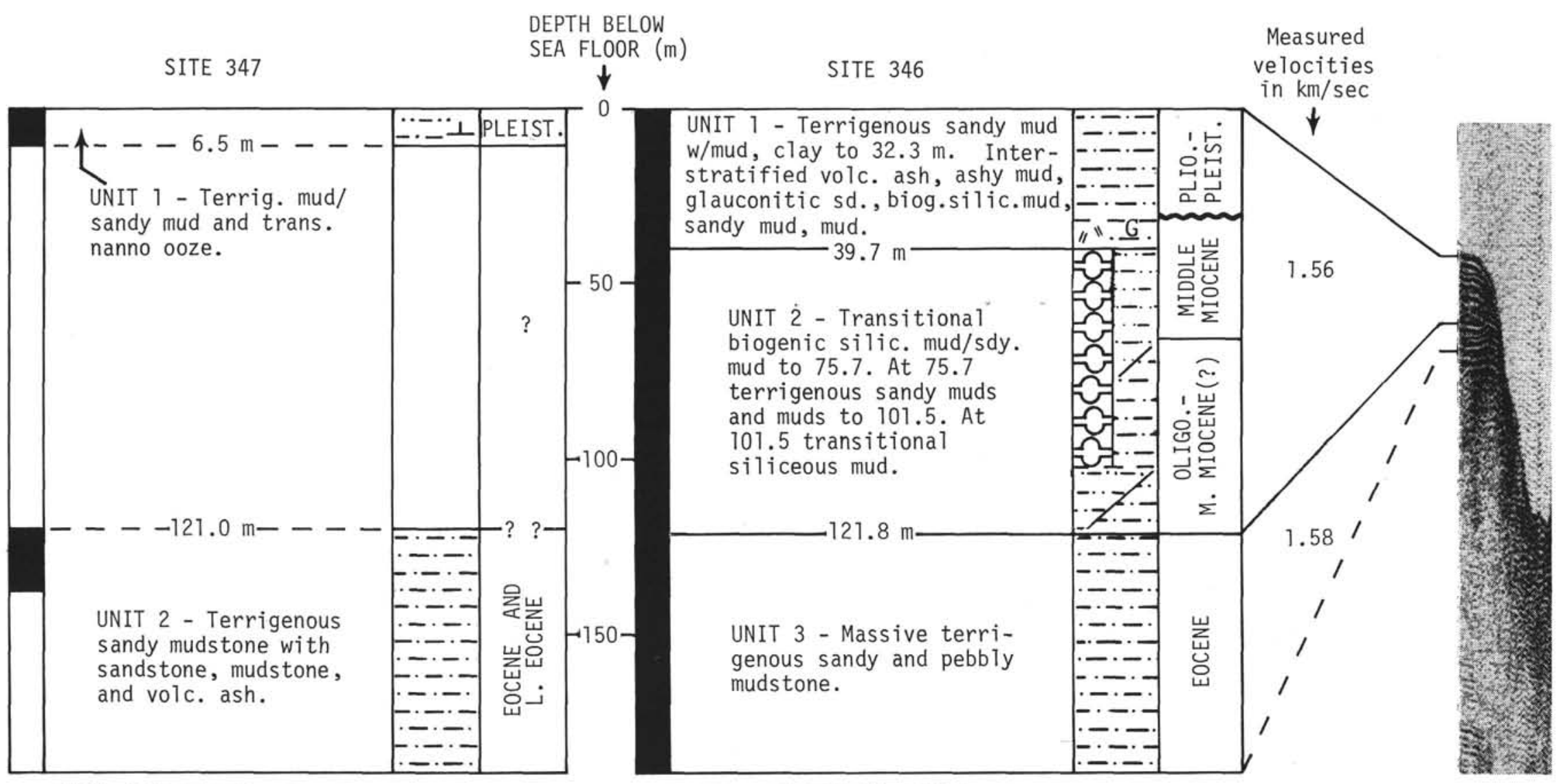

TOTAL PENETRATION: 190.0 meters

TOTAL PENETRATION: 187.0 meters

Figure 5. Lithologic summary and seismic profile, Sites 346, 347. 
TABLE 6

Lithologic Summary, Site 349

\begin{tabular}{|c|c|c|c|}
\hline Unit & $\begin{array}{l}\text { Depth (m) } \\
\text { and Core } \\
\text { Numbers }\end{array}$ & Age & Characteristics \\
\hline 1 & $\begin{array}{l}0.0-59.3 \\
(1-0 \text { to } 2-4 \\
100 \mathrm{~cm}) \\
\text { thickness- } \\
59.3 \mathrm{~m}\end{array}$ & Pleistocene & $\begin{array}{l}\text { Massive mud and sandy mud } \\
\text { with scattered volcanic ash; } \\
\text { intensely deformed; soft; } \\
\text { locally mottled; locally glau- } \\
\text { conite-rich }\end{array}$ \\
\hline 2 & $\begin{array}{l}59.3-119.6 \\
(2-4,100 \text { to } \\
5-4,130 \mathrm{~cm}) \\
\text { thickness- } \\
60.3 \mathrm{~m}\end{array}$ & $\begin{array}{l}\text { Pleistocene- } \\
\text { Late } \\
\text { Eocene }\end{array}$ & $\begin{array}{l}\text { Massive mud with abundant } \\
\text { volcanic ash in the upper } \\
\text { part and glauconite in the } \\
\text { upper and lower part; in- } \\
\text { tensely to moderately de- } \\
\text { formed; soft to firm; locally } \\
\text { mottled }\end{array}$ \\
\hline 3 & $\begin{array}{l}119.6-319.5 \\
(5-4,130 \text { to } \\
13, \mathrm{CC}) \\
\text { thickness- } \\
199.9 \mathrm{~m}\end{array}$ & $\begin{array}{l}\text { Late } \\
\text { Eocene- } \\
\text { early } \\
\text { Oligocene }\end{array}$ & $\begin{array}{l}\text { Sandy mudstone and mud- } \\
\text { stone with conglomerate, } \\
\text { breccia, and sandstone inter- } \\
\text { beds; indurated and unde- } \\
\text { formed; locally bioturbated; } \\
\text { pyrite nodules and calcareous } \\
\text { zones abundant; graded beds } \\
\text { common; almost wholly ter- } \\
\text { rigenous; locally zeolite } \\
\text { rich }\end{array}$ \\
\hline
\end{tabular}

and foraminifera, calcareous nannofossils, sponge spicules, and radiolarians are also present.

Unit 2 (Pleistocene to late Eocene; thickness $66.9 \mathrm{~m}$ )

Unit 2 consists primarily of massive mud with significant amounts of volcanic ash in the upper part and glauconite in the upper and lower parts. Colors in- clude shades of green and gray. It is intensely to moderately deformed, and soft to firm throughout. Locally it is intensely mottled. Ash-rich units are present only in the lower part of Core 2 .

The sediments consist mostly of clay minerals and quartz, but include locally large amounts of mica, volcanic glass, palagonite, glauconite, and sponge spicules. Minor amounts of other detrital minerals, zeolites, authigenic carbonate, diatoms, and radiolarians are also present.

\section{Unit 3 (Upper Eocene to lower Oligocene, minimum thickness $199.9 \mathrm{~m})$}

Unit 3 consists of intermixed mudstone and sandy mudstone, abundant conglomerate, breccia, and sandstone. Graded sequences are present in the lower twothirds of the unit. The unit is indurated almost throughout and undeformed except for minor amounts of drilling breccia. Bioturbation is locally common, as are pyrite nodules and calcareous layers.

The mudstone/sandy mudstone is composed of quartz and clay minerals with smaller and variable amounts of mica, feldspar, authigenic carbonate, lithic fragments, and minor amounts of heavy minerals, opaque minerals, micronodules, zeolite minerals, glauconite, and volcanic glass.

The conglomerate and breccia contain abundant clasts of sedimentary rocks, primarily mudstone, sandy mudstone, claystone, and sandstone; harder clasts of volcanic(?) rocks, limestone(?), chert, and quartz are also present. The clasts are angular to round and as long as $8 \mathrm{~cm}$. Both graded and ungraded conglomerate/breccia zones are present.

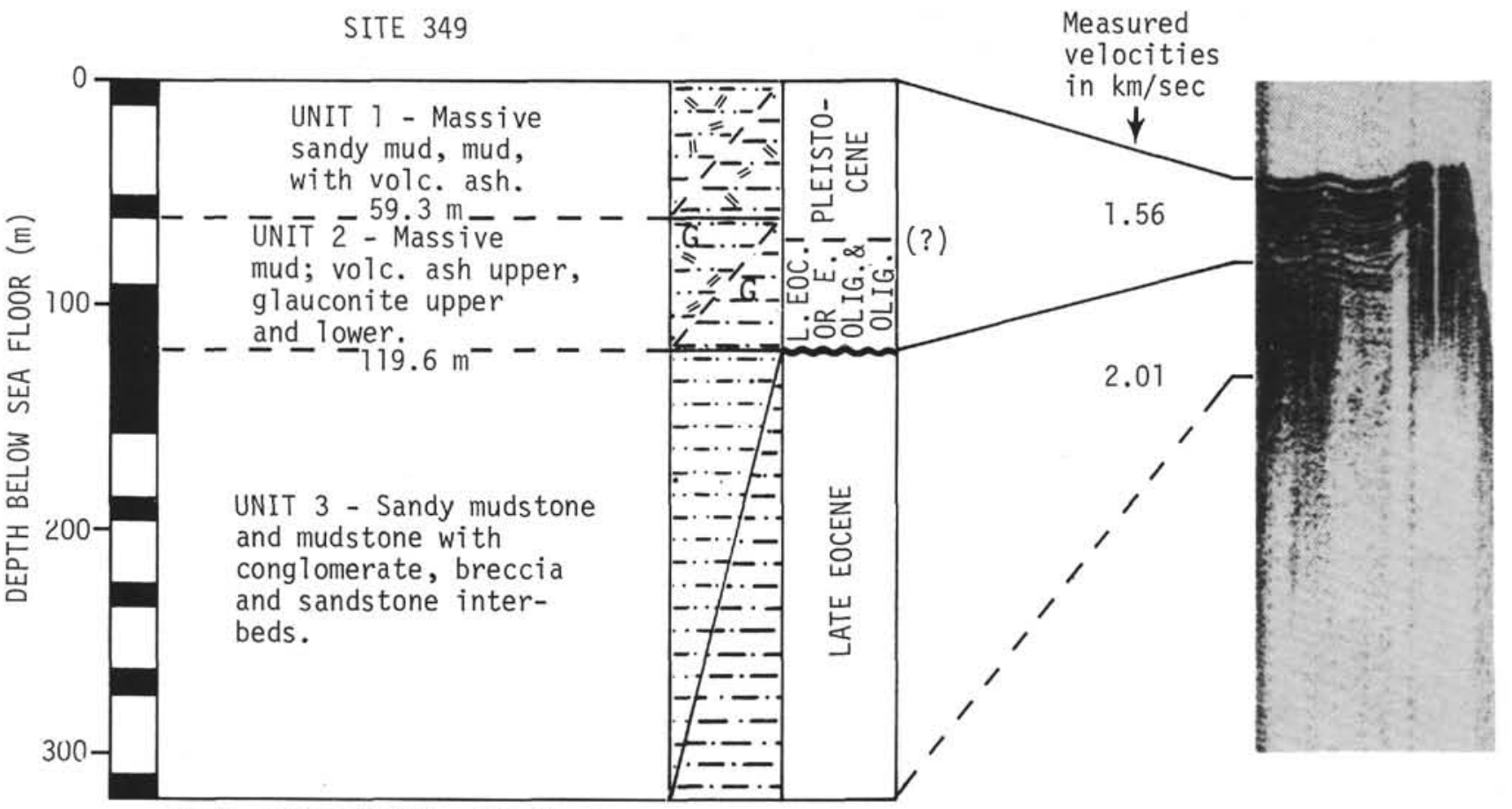

TOTAL PENETRATION: 319.5 meters

Figure 6. Lithologic summary and seismic profile, Site 349. 


\section{Interpretation}

Unit 1 presumably represents glacial-marine sedimentation during the late Cenozoic, but may include postglacial Holocene sediments. The boundary between Units 1 and 2 is not certain, but appears to lie within Core 2, where the upper part of the core consists of yellowish-brown sandy mud and mud similar to the sequence in Core 1 . The transition downward to Unit 2 is marked by the presence of abundant volcanic ash, the first appearance of significant amounts of glauconite, color change from yellowish-brown to greenish-gray, relatively abundant sponge spicules, changing amounts and types of biogenic constituents, and sharp changes in cohesiveness and other physical properties. The boundary appears to be adjacent to an unconformity separating Pleistocene and Oligocene sediments.

The processes responsible for the deposition of the muds and sandy muds of Unit 2 are not clear, inasmuch as sedimentary structures and other features indicative of sedimentary processes are lacking; the lack of sorting and current-formed structures probably indicates the absence of strong current activity. Presumably, hemipelagic sedimentation and reworking, as well as erosion of older strata may have supplied most of the detritus. The depth of deposition cannot be determined from sedimentary features.

The boundary between Units 2 and 3 is marked by a basal conglomerate that separates older lithified strata from younger unconsolidated sediments. There is no indication of subaerial weathering or erosion.

Unit 3 represents a complex sedimentary facies, including pebbly mudstones, sandstones, turbidites, and hemipelagic sediments. Unfortunately, because of large gaps in coring and the undetermined base of this unit, the history of sedimentation that it represents cannot be adequately reconstructed.

\section{PHYSICAL PROPERTIES, SITES 346 AND 347}

Figure 7 shows uncorrected GRAPE (bulk) density, sonic velocity, and acoustic impedance at Site 346 with depth. The section is differentiated into two distinct units: (1) a lower high density sediment possessing high $(>2.0 \mathrm{~km} / \mathrm{sec})$ sonic velocity, and (2) an upper unit with low bulk density and low sonic velocity. The abrupt change in acoustic impedance at Core 14, Section 2 indicates the lower unit is a strong reflector of sound, and would be expected to be visible on seismic profile records. Within the upper unit, Cores 5 and 6 show a sonic velocity variation that is not matched by the other parameters. However, as only core averages are shown in the figure, fine-scale variation is removed, and only generalizations concerning the sediments can be made.

Accordingly, Figure 8 is a plot of bulk density for each core section in the upper unit. Although a greater scatter of points results, five separate subunits can be seen (Table 7).

At Site 347 only four cores were taken, hence, no continuity of physical property data exists. As the emphasis was placed on the nature of the basement and not the overlying sediments, only a few physical property measurements were made, sufficient to determine the general character of the sediments.
The data in Table 8 are core averages for Site 347 . No water content measurements were made.

\section{Physical Properties Summary}

The gross stratigraphy of Site 346 shows a two-part division, based upon average wet density and velocity values for each core. The Miocene(?) unit is clearly shown to have high compressive strength, high density and velocity, and high acoustic impedance. It is a significant reflector at 132 meters and should be clearly visible on seismic profiles records.

\section{PHYSICAL PROPERTIES, SITE 349}

Physical properties (sonic velocity, GRAPE [wet] density) outline the general stratigraphy (Figure 9) consisting of two distinct units.

The sediments are clearly differentiated by the abrupt change in sonic velocity, beginning in the sediments below the conglomerate in Core 5 , Section 6 , and continuing at a high velocity to the base of the hole. Within the late Eocene some extreme values are noted, probably related to lithologic variability. Sonic velocity above the unconformity is consistent at about 1.57 $\mathrm{km} / \mathrm{sec}$, a speed normally found in the Quaternary and late Tertiary sediments.

Table 9 lists average physical properties for the two units,

\section{GEOCHEMISTRY}

\section{Inorganic Geochemistry}

Interstitial water analyses were performed only on sediments from Sites 346 and 349 . The data are found in Tables 10 and 11 .

\section{Organic Geochemistry}

Shipboard Analysis of Dissolved Gas

in Tertiary Cores from Sites 346, 347, and 349

The presite survey suggested the possibility that Site 346 might penetrate an angular unconformity into possibly pre-Tertiary sediments. Consequently, the hole was monitored closely for the presence of gas and hydrocarbons. A 26-cc gas sample was recovered from Section 346-3-1, and a 30-cc sample from Section 346-32 , but analysis indicated both consisted only of air. No occurrences of hydrocarbons were encountered at Sites 346,347 , and 349 .

\section{BIOSTRATIGRAPHY, SITE 346}

\section{Biostratigraphic Summary}

"Glacial" sediments (Pliocene to Pleistocene) were recovered in Cores 1 to $3(0-25.5 \mathrm{~m})$ characterized by left-coiled Globigerina pachyderma, few nannofossils, and some cold water radiolarians. Ice-rafted material and reworked nannoplankton and pollen are less abundant compared with "glacial" sediments of previous sites. This may indicate that this site was often under permanent ice cover with low organic production, and receiving little ice-rafted material.

Siliceous microfossils of Cores 4 to 11 (25.5-101.5 m) are generally rare and poorly preserved. In Core 5 , Sec- 


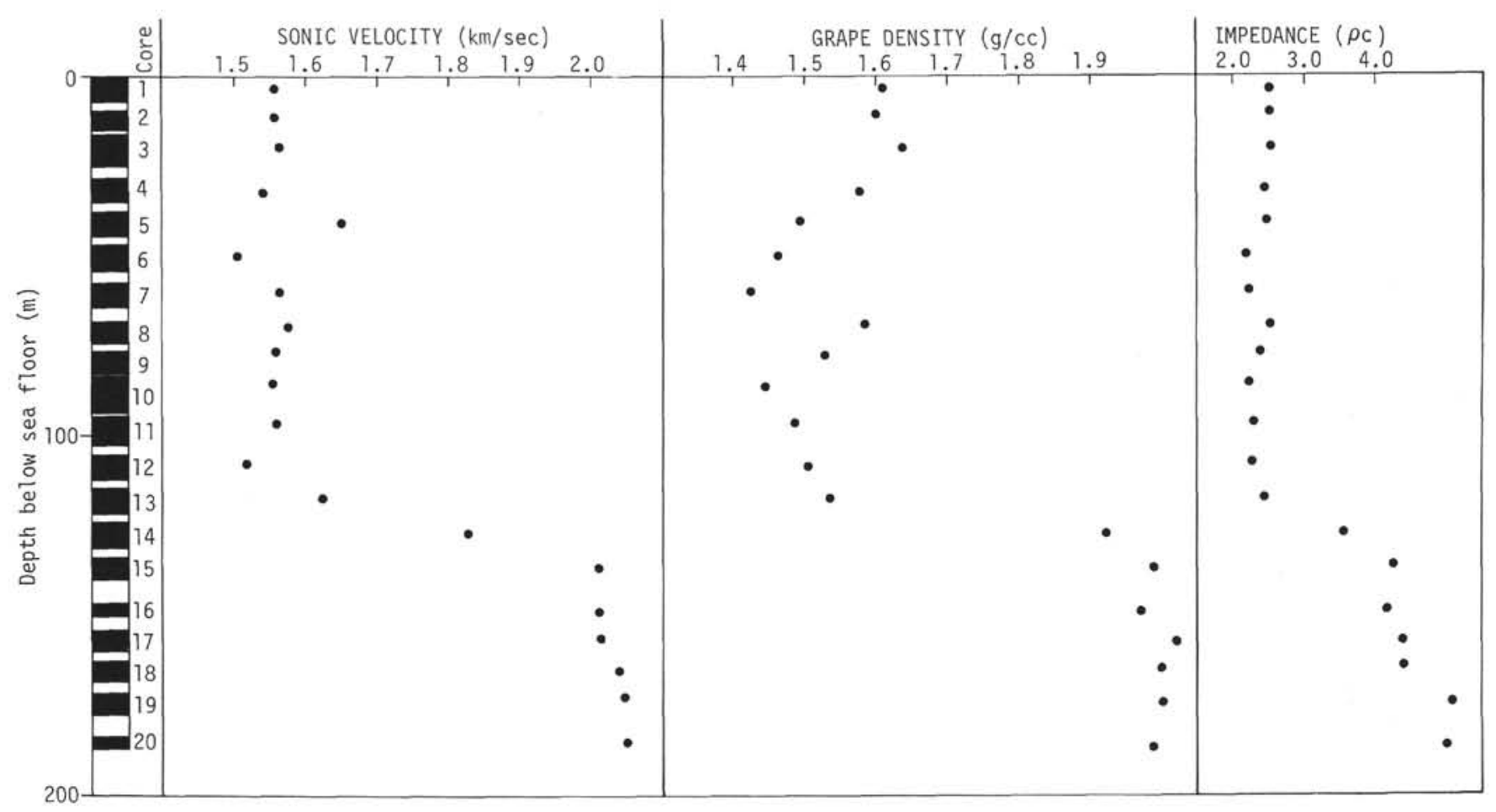

Figure 7. Density, velocity, impedance, Site 346.

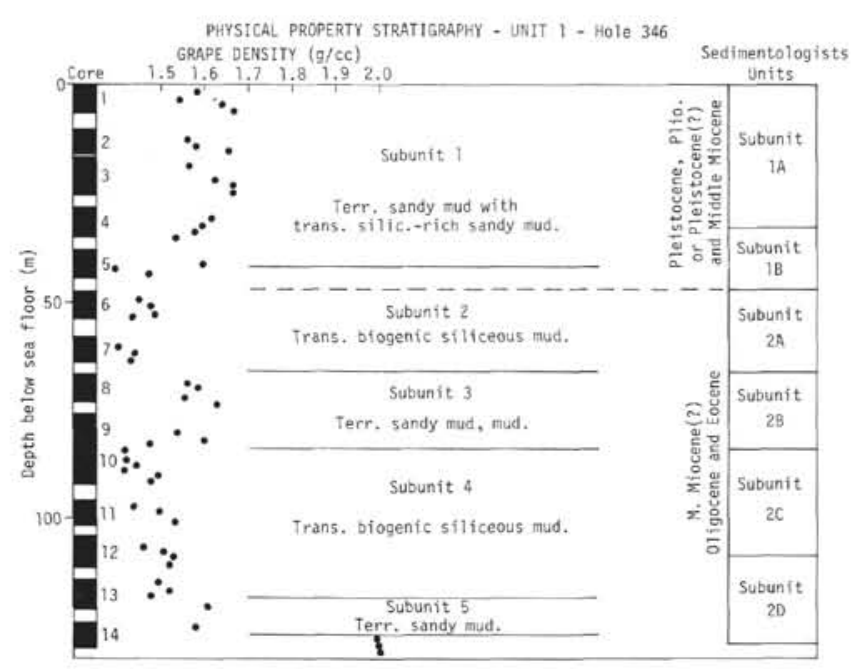

Figure 8. Density profile - Cores 1-14, Site 346.

tion 1, a diatom assemblage of Pliocene age was found. They indicate for Core 5, Section 3 to Core 11 a middle Miocene age. This indicates a hiatus including at least the upper Miocene. The sequence is abundant in sponge spicules which can be interpreted as being an indication for displaced sediments from shallow water, but in this case it seems more likely to be a dissolution effect.

In Core 12 only sponge spicules were found which do not allow a determination of age. For Core 13 (111$120.5 \mathrm{~m})$ a few corroded foraminifera suggest an Oligocene age, which is supported by dinoflagellates. From Core 14 down through Core 20 (120.5-187 m) only dinoflagellates and foraminifera are present, largely siliceous tests, giving an Eocene age.

\section{Foraminifera}

\section{"Glacial," Pleistocene, Core 1 through Sample 4-5, $125 \mathrm{~cm}$}

The upper cores are characterized by the abundance of sinistral Neogloboquadrina pachyderma. During reconnaissance examination of more than 50 samples, only three specimens of other planktonic foraminiferal species were seen; as a whole the fauna is cooler than at

TABLE 7

Sediment Units (Site 346) Based on Physical Properties

\begin{tabular}{|c|c|}
\hline \multicolumn{2}{|r|}{ Unit 1} \\
\hline Subunit 1 - & $\begin{array}{l}\text { Extending from the surface to Core } 5 \text {, Section } 3 \\
\text { Avg. density }-1.605 \mathrm{~g} / \mathrm{cc} \\
\text { Avg. water content }-35.07 \% \\
\text { Avg. velocity }-1.565 \mathrm{~km} / \mathrm{sec}\end{array}$ \\
\hline Subunit 2 - & $\begin{array}{l}\text { Extending from Core } 5 \text {, Section } 3 \text { to Core } 8 \text {, Section } 2 \\
\text { Avg. density }-1.447 \mathrm{~g} / \mathrm{cc} \\
\text { Avg. water content }-43.83 \% \\
\text { Avg. velocity }-1.533 \mathrm{~km} / \mathrm{sec}\end{array}$ \\
\hline Subunit 3 - & $\begin{array}{l}\text { Extending from Core } 8 \text {, Section } 2 \text { to Core } 9 \text {, Section } 6 \\
\text { Avg. density }-1.580 \mathrm{~g} / \mathrm{cc} \\
\text { Avg. water content }-36.74 \% \\
\text { Avg. velocity }-1.565 \mathrm{~km} / \mathrm{sec}\end{array}$ \\
\hline Subunit 4 - & $\begin{array}{l}\text { Extending from Core } 9 \text {, Section } 6 \text { to Core } 13 \text {, Section } 4 \\
\text { Avg. density }-1.479 \mathrm{~g} / \mathrm{cc} \\
\text { Avg. water content }-38.77 \% \\
\text { Avg. velocity }-1.564 \mathrm{~km} / \mathrm{sec}\end{array}$ \\
\hline Subunit 5 - & $\begin{array}{l}\text { Extending from Core } 13 \text {, Section } 4 \text { to Core } 14 \text {, Section } 2 \\
\text { Avg. density }-1.597 \mathrm{~g} / \mathrm{cc} \\
\text { Avg. water content }-31.75 \% \\
\text { Avg. velocity }-1.588 \mathrm{~km} / \mathrm{sec}\end{array}$ \\
\hline
\end{tabular}


TABLE 8

Representative Density, Porosity, Velocity, and Impedance Values, Site 347

\begin{tabular}{|c|c|c|c|c|c|c|}
\hline Core & $\begin{array}{l}\text { Depth } \\
\text { (m) }\end{array}$ & $\mathrm{p}(\mathrm{g} / \mathrm{cc})$ & $\eta(\%)$ & $c(\mathrm{~km} / \mathrm{sec})$ & $\mathrm{pc}$ & $\begin{array}{c}\text { Correlation with } \\
\text { Site } 346\end{array}$ \\
\hline 1 & $0-4.5$ & 1.540 & 72.79 & 1.934 & 2.98 & Quaternary \\
\hline 2 & $121-128$ & 2.054 & 39.08 & 2.707 & 5.56 & $\begin{array}{l}\text { Unit 2- } \\
\text { late Eocene }\end{array}$ \\
\hline 3 & $128-137.5$ & 2.002 & 42.49 & 3.082 & 6.17 & $\begin{array}{l}\text { Unit 2- } \\
\text { late Eocene }\end{array}$ \\
\hline 4 & $187-190$ & 1.951 & 45.82 & - & - & $\begin{array}{l}\text { Unit 2 - } \\
\text { late Eocene }\end{array}$ \\
\hline
\end{tabular}

the more eastern sites. Except for the lowest part practically all samples are fossiliferous suggesting that there were no extended periods with thick enough ice coverage to prevent light penetration and pelagic life. The benthonic fauna has the usual low diversity, but may in general have some more and different species than elsewhere which is probably due to its shallower water depth. The most common species are: Islandiella teretis, I. norcrossi, Melonis zaandamae, Bulimina aculeata, and "Cibicides" sp.
Most washed residues contain basalt fragments and other volcanic material and some spicules in addition to the ice-rafted quartz, rock-fragments, and Cretaceous Inoceramus prisms. A specimen of the Late Cretaceous Globigerinelloides messinae was found in Sample 4-2, $113-115 \mathrm{~cm}$.

The base of the "glacial" interval lies in Core 4, Section 5 but is not immediately apparent because the section is barren and somewhat disturbed and mixed. The lowest sample with $N$. pachyderma is $4-5,18-20 \mathrm{~cm}$.

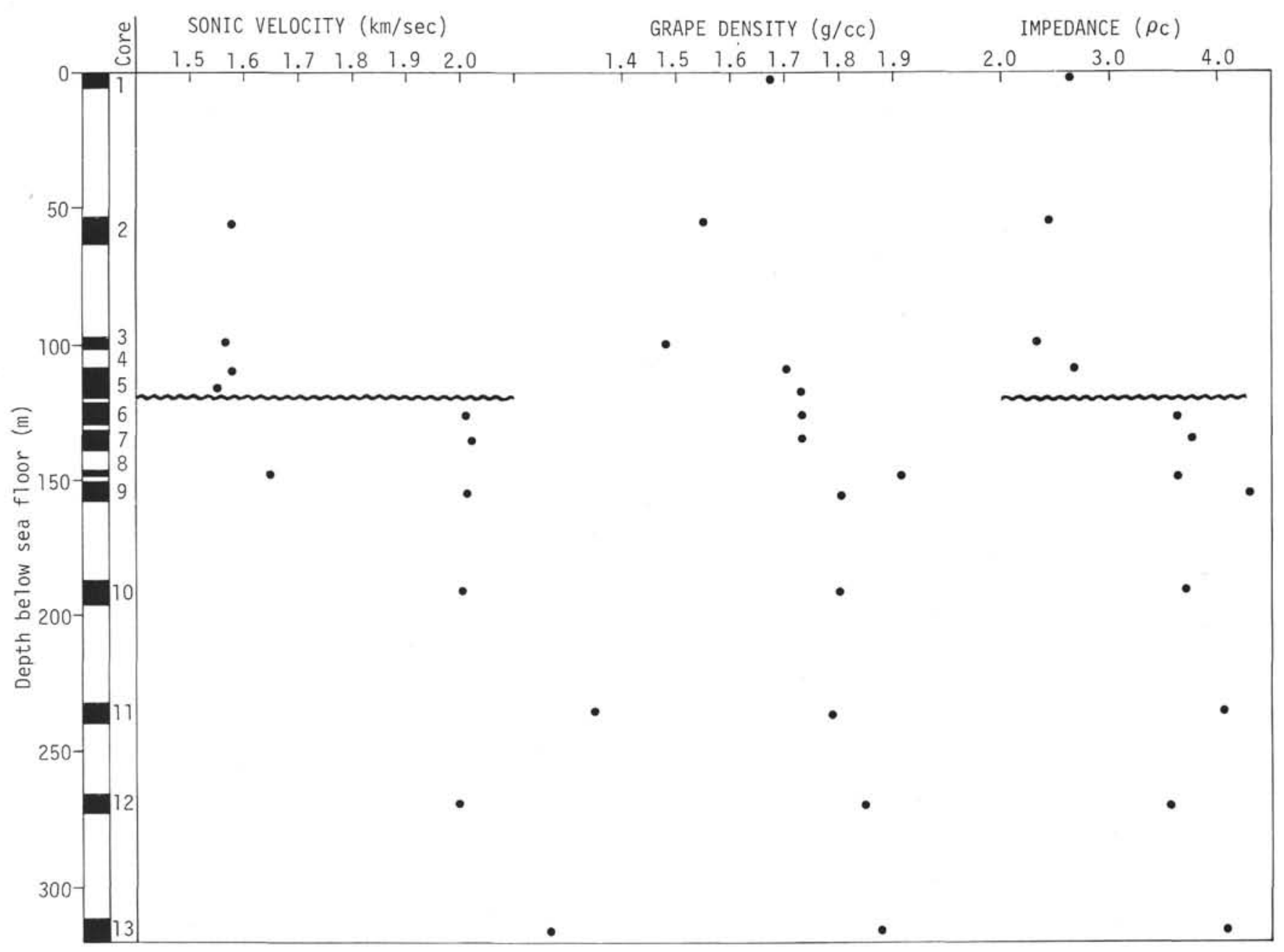

Figure 9. Velocity, density, impedance, Site 349. 
TABLE 9

Average GRAPE Density, Velocity, Impedance of Sediment Units, Site 349

\begin{tabular}{|c|c|c|c|}
\hline Unit & $\begin{array}{l}\text { GRAPE } \\
\text { Density } \\
\rho \text { (g/cc) }\end{array}$ & $\begin{array}{c}\text { Sonic } \\
\text { Velocity } \\
(\mathrm{km} / \mathrm{sec})\end{array}$ & Impedance \\
\hline $\begin{aligned} 1 & \bar{x} \\
& s\end{aligned}$ & $\begin{array}{l}1.617 \\
0.117\end{array}$ & $\begin{array}{l}1.570 \\
0.015\end{array}$ & $\begin{array}{l}2.56 \\
0.16\end{array}$ \\
\hline $2 \bar{x}$ & $\begin{array}{l}1.815 \\
0.067\end{array}$ & $\begin{array}{l}2.055 \\
0.192\end{array}$ & $\begin{array}{l}3.72 \\
0.29\end{array}$ \\
\hline
\end{tabular}

Below it the relative amount of volcanic material is high and several samples have a large number of yellowish rusty grains (locally derived from Tertiary sediment?). From 4-5, 114-116 cm down, the heterogeneous residue contains, in addition, glauconite and coated grains, and undisintegrated fragments of a "rusty crust" become common, representing upward mixing of a "hardground" that has its top in Section 5 at $125 \mathrm{~cm}$.

\section{Mio-Pliocene, Sample 4-5, $125 \mathrm{~cm}$ through Core 5, Section 3}

Washed residues from this interval are barren of foraminifera and consist of glauconite with some rounded quartz, sponge spicules, and radiolarians. The lower boundary of this unit lies between Samples 5-3, $55-57 \mathrm{~cm}$ and 5-4, 50-52 $\mathrm{cm}$.

\section{Oligo-Miocene, Sample 5, CC through Core 13, Section 4}

Residues of sediment from this interval consist of sponge remains (spicules and skeleton fragments) and rounded quartz grains and rock fragments with a varying amount of volcanic material (glass, ash, pumice). A few samples have some fecal pellets and fish remains. Pyrite is present (and often abundant) from Core 9, Section 5 down. Sample 5, CC is the only one from this sandy sponge reef that yielded foraminifera: a few specimens of Spirosigmoilinella $\mathrm{sp}$. and Spirolocammina sp. The occurrence of Miocene diatoms in Core 11 and Oligocene dinoflagellates in Core 12 suggests that the Oligo-Miocene boundary can be drawn between these cores at 100 meters.

\section{Oligocene, Samples 13, CC through 14-2, $125 \mathrm{~cm}$}

Sponge remains are not abundant or not present in washed residues, whereas small fecal pellets are abundant. Two samples yielded fragments or corroded tests of calcareous foraminifera, two of which can be identified as the Oligocene Angulogerina gracilis. The others are unidentifiable Lenticulina sp. and "Cibicides" sp. The base of this unit lies between Samples 14-2, 124-126 $\mathrm{cm}$ and 14-2, 132-134 cm.

\section{Eocene, Sample 14-2, $130 \mathrm{~cm}$ through Core 20}

All washed residues consist of badly sorted, immature sand (angular and rounded quartz, feldspar, rock-fragments, bipyramidal quartz), and arenaceous foraminifera. Prominent genera are Psammosphaera, Rhabdammina, Bathysiphon, Tolypammina (Ammolagena), and Cyclammina. A few calcareous specimens of large "Cibicides" sp. and Lenticulina cultrata probably were redeposited from shallower depths. The occurrence of Spiroplectammina spectabilis in Samples 17, CC and 19, CC confirms the Eocene age of this unit as suggested by dinoflagellate occurrence.

Contrary to the soft sediment immediately above, this unit is well consolidated (difficult to sample), and its top is a marked disconformity.

\section{Nannoplankton}

Nannofossils are present only in Core 1 and very few in Core $2(0-16 \mathrm{~m})$ of Quaternary sediments. Core 1 belongs to the Emiliania huxleyi Zone (NN 21), with Emiliania huxleyi, Coccolithus pelagicus, Gephyrocapsa ericsonii, and some specimens of Cyclococcolithus leptoporous. Only few reworked species of the Cretaceous

TABLE 10

Summary of Shipboard Geochemical Data, Site 346

\begin{tabular}{lcccccc}
\hline $\begin{array}{c}\text { Sample } \\
\text { (Interval in cm) }\end{array}$ & $\begin{array}{c}\text { Subdepth } \\
(\mathrm{m})\end{array}$ & $p \mathrm{H}$ & $\begin{array}{c}\text { Alkalinity } \\
(\mathrm{meq} / \mathrm{kg})\end{array}$ & $\begin{array}{c}\text { Salinity } \\
(\% / \mathrm{l})\end{array}$ & $\begin{array}{c}\mathrm{Ca}++ \\
(\mathrm{mmoles} / \mathrm{l})\end{array}$ & $\begin{array}{c}\mathrm{Mg}++ \\
(\mathrm{mmoles} / \mathrm{l})\end{array}$ \\
\hline Surface Seawater & - & 8.15 & 2.37 & 35.2 & 10.27 & 52.10 \\
$1-4,144-150$ & 6.0 & 7.44 & 3.05 & 34.6 & 11.28 & 52.18 \\
$4-4,144-150$ & 31.5 & 8.32 & 3.94 & 35.2 & 13.07 & 48.87 \\
$6-4,144-150$ & 50.5 & 7.47 & 3.54 & 35.2 & 13.29 & 47.71 \\
$9-5,144-150$ & 80.5 & 7.27 & 3.45 & 35.2 & 14.40 & 47.32 \\
$12-3,144-150$ & 106.0 & 7.74 & 3.58 & 35.2 & 14.65 & 40.06 \\
$15-4,141-150$ & 136.0 & 7.95 & 2.00 & 35.2 & 15.16 & 44.62 \\
$17-1,144-150$ & 150.5 & - & 1.88 & 35.2 & 16.52 & 39.37 \\
\hline
\end{tabular}

TABLE 11

Summary of Shipboard Geochemical Data, Site 349

\begin{tabular}{lcccccc}
\hline $\begin{array}{c}\text { Sample } \\
\text { (Interval in cm) }\end{array}$ & $\begin{array}{c}\text { Subdepth } \\
(\mathrm{m})\end{array}$ & $p \mathrm{H}$ & $\begin{array}{c}\text { Alkalinity } \\
(\mathrm{meq} / \mathrm{kg})\end{array}$ & $\begin{array}{c}\text { Salinity } \\
(\% \%)\end{array}$ & $\begin{array}{c}\mathrm{Ca}++ \\
(\mathrm{mmoles} / \mathrm{l})\end{array}$ & $\begin{array}{c}\mathrm{Mg}++ \\
(\mathrm{mmoles} / \mathrm{l})\end{array}$ \\
\hline Surface Seawater & - & 8.11 & 2.31 & 34.6 & 10.23 & 52.50 \\
$1-3,144-150$ & 4.5 & 7.43 & 3.19 & 34.9 & 11.24 & 51.06 \\
$2-5,144-150$ & 61.0 & 7.91 & 3.42 & 34.6 & 13.21 & 45.27 \\
$5-4,144-150$ & 116.5 & 7.75 & 2.71 & 34.4 & 12.79 & 47.85 \\
$10-5,140-150$ & 194.0 & 7.82 & 1.32 & 34.1 & 14.21 & 33.87 \\
\hline
\end{tabular}


and Eocene were found. All other cores are barren of nannoplankton. Only in Sample 4-2, 37-38 cm (25.5-35 m) were a few specimens of Cyclococcolithus leptoporous, Coccolithus pelagicus, and Helicosphaera carteri observed.

\section{Diatoms (H.-J.S.)}

Diatom assemblages were found from Core 5 through Core 11 with variable abundances and preservation. Commonly, assemblages are poorly preserved. Therefore the biostratigraphic zonation described below is tentative and is based on using the youngest index species being found in a stratum and interpreting other index species present as being reworked. This assumption is evidenced by the simultaneous enrichment of marine benthonic displaced species (A rachnoidiscus, Hyalodiscus, Grammatophora, and Cocconeis). The almost constant presence of sponge spicules in small numbers can be also interpreted as being an indication for displacement of shallow material, and/or by the dissolution effect. The latter leads to badly preserved assemblages and enriches skeletons, which are heavily silicified. A sudden increase in individuals of the genus Goniothecium (odontella/decoratum) in Sample 9-5, $40 \mathrm{~cm}$ and deeper is interpreted as a change in facies from shallower to deeper.

As mentioned above, the biostratigraphic zonation is tentative and is based for Sample $5-1,60 \mathrm{~cm}$ on the occurrence of Thalassiosira nidulus and abundant Rhizosolenia barboi, which place Samples 5-1, $30 \mathrm{~cm}$ to $5-1$, $60 \mathrm{~cm}$ into the Thalassiosira kryophila and/or into the Rhizosolenia barboi zones (age: 1.8 to approximately 3.5 m.y.). The interval between Samples 6-2, $30 \mathrm{~cm}$ to 12-1, $105 \mathrm{~cm}$ is characterized by abundant Goniothecium tenue and under the assumption that individuals of this species in Samples 10-3, $20 \mathrm{~cm}$; 11-2, $25 \mathrm{~cm}$; and 11-4, $40 \mathrm{~cm}$ do differ in shape and structure from previously known samples by being heavily silicified and some being structured, they were not put into the range of Goniothecium tenue, and thus the following subdivision was possible: interval between Samples 5-3, $95 \mathrm{~cm}$ to 8$2,30 \mathrm{~cm}$ is of middle Miocene age; interval between Samples $9-5,40 \mathrm{~cm}$ to $11-4,40 \mathrm{~cm}$ can be placed into the Coscinodiscus plicatus Zone; and Samples 11-4, 40 $\mathrm{cm}$ into the early Miocene with reworked early early Miocene and late Oligocene species (Trinacria excavata, Pseudotriceratium cheneveri, Cymatosira spp.).

\section{Radiolarians}

Three units can be recognized.

Unit 1 (Cores 1 through 3 ) is rich in ice-rafted material having rare and poorly to moderately preserved radiolarians such as Pseudodyctophimus gracilipes, Amphimelissa setosa, and Cycladophora davisiana, which are typical for the modern Norwegian Sea fauna.

Unit 2 (Cores 4 through 11) is not well defined at the base, as radiolarians in Core 8 through 11 are very poorly preserved. Compared with Site 338, Cores 4 through 7 can be referred to the lowermost part of the Actinomma holtedahli Zone, giving an age of upper early Miocene to lower middle Miocene.
Unit 3 (Cores 12 through 20) is characterized by being barren in siliceous microfossils.

\section{Silicoflagellates}

Silicoflagellates are rare from Sample 4-5, 40-41 cm to Sample $11-4,75-76 \mathrm{~cm}$ (33.5-98 m); below only sponge spicules and archaeomonads were found.

Few silicoflagellates were observed from Sample 4-5, $40-41 \mathrm{~cm}$ to Sample 5-2, 131-132 cm. They become more common from Sample 5-3, 50-51 cm to Sample 6$2,85-86 \mathrm{~cm}$. Below, a decrease in abundancy down to Sample 12, CC is noted. The assemblage from Sample $5-3,50-51 \mathrm{~cm}$ consists of Corbisema triacantha, Distephanus crux, Mesocena apiculata, Cannopilus hemisphaericus, Dictyocha fibula, and Distephanus speculum indicating a middle Miocene age (Dictyocha triacantha Zone). Archaeomonads are generally abundant in all samples. Below Sample 12, CC sediments are barren of silicoflagellates.

\section{Palynology (S.B.M.)}

\section{Dinocysts}

Good diagnostic assemblages were obtained only from Core 6, Section 4 and Core 5, Section 3. Both compare well with Zone II of Site 338 and may be assigned to Subzone IIa (5-3 fairly confidently, 6-4 with some reservation). Core 7 , Section 3 gave a somewhat poorer Zone II assemblage. In samples from a few other cores, scattered specimens of fairly diagnostic species allow comparison with Site 338. Thus, Core 12, Section 1 and Core 12, Section 3 produced a few specimens of Leptodinium sp. II, cf. Plathycystidia sp. I, and Operculodinium cf. centrocarpum suggesting Zone III. In Core 15, Section 3 and Core 16, Section 1 which contain predominantly reworked material, Deflandrea phosphoritica and Areosphaeridium arcuatum appear indigenous, and Zone IV or V is therefore suggested for this part (Figure 10).

\section{Debris, Reworked Material}

Preparations from all cores have a prominent terrestrial plant debris component, dominating in most cases. Distinct changes in debris composition are observed between Core 14, Section 3, and Core 14, Section 2, and between Core 9, Section 2 and Core 8, Section 5. Below Core 14, Section 2, reworked material appears corroded and moderately altered, including pollen of fairly young age (early Tertiary: Tiliaepollenites, triporate). The interval 14-2 to 9-2 has a varied debris composition, rich in well-preserved cuticle fragments, although thermal alteration appears to be slight to moderate. Presence of the cysts Odontochitina operculata and Gonyaulacysta orthoceras suggests a Cretaceous age for reworked material. Most of the pollen and spores are consistent with this age, but some reworked early Tertiary pollen are also present.

From Core 8, Section 5 upwards, the debris tend to be dominated by carbonized tracheidal matter. Occasional reworked cysts of Cretaceous as well as early Tertiary age are present. 


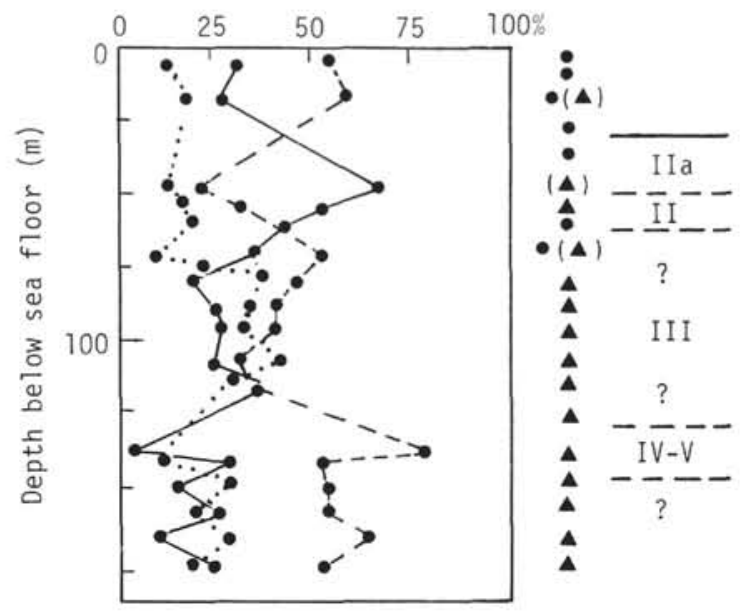

Figure 10. Relative palynomorph abundance and palynodebris composition, Site 346. - dinocysts, - - pollen + spores (excl. saccates), . . . Saccate pollen; terrestrial plant debris: mixed cuticular and tracheidal, $\mathbf{\Delta}$ altered (dark color), $\Delta$ unaltered, sorted, tracheidal mainly - carbonized (opaque), o noncarbonized,-no recognizable debris, ( ) debris present but not dominating in prep. residue; symbol only: debris dominating.

\section{BIOSTRATIGRAPHY, SITE 347}

\section{Biostratigraphic Summary}

Sediments recovered in this hole are barren of siliceous microfossils, only in Sample 1, CC a wellpreserved radiolarian assemblage is present representing probably an interglacial. In Core 1, planktonic foraminifera (only Globigerina pachyderma), arenaceous foraminifera and deep water benthonic species are present. Nannoplankton is restricted to some nannofossil ooze layers. Reworked Cretaceous and Paleogene species are only rare in this Quaternary sequence.

In Cores 2 through $4(121-190 \mathrm{~m})$ arenaceous foraminifera, few nannofossils, and dinoflagellates are present indicating a late Eocene to probable middle Eocene age.

\section{Foraminifera}

\section{“Glacial," Pleistocene, Core 1}

Sinistrally coiling Neogloboquadrina pachyderma is abundant in all samples of this core. Only very few Globigerina bulloides and G. quinqueloba were observed. The benthos is dominated by Islandiella teretis and Melonis zaandamae, but the assemblage in most samples also has common Pullenia bulloides, Eponides umbonatus, Islandiella islandica, "Cibicides" spp., and rare Lagena spp., Fissurina sp., Angulogerina sp., Astrononion gallowayi, and Rupertia stabilis. However, the most distinctive character of the fauna of this core is the common presence in the coarse fractions of arenaceous benthonic foraminifera: Psammosphaera, Recurvoides, Hyperammina, Reophax, and other coarsegrain walled forms.
There is relatively less ice-rafted material than at other sites, most residues consisting of more than 50\% foraminiferal tests. Sponge spicules and volcanic glass are common. The effect of carbonate dissolution increases noticeably downward in the core.

\section{Eocene, Cores 2 through 4}

As is the case for samples below the unconformity at Site 346, washed residues of Cores 2 through 4 consist of immature sand with an arenaceous benthonic foraminiferal fauna: Cyclammina (up to $3.5 \mathrm{~mm}$ in diameter), Psammosphaera and Rhabdammina, with further Bathysiphon, Recurvoides, Reophax, Ammodiscus, Textularia, Gaudryina, and the Eocene marker Spiroplactammina spectabilis. A few large calcareous tests are present in Cores 2 and 3: Lenticulina decorata, Lenticulina cultrata, and Nodosaria latejugata which suggest a late Eocene age (cf: NW Germany, Bettenstaedt et al., 1962).

The fauna near the base of the Eocene at Site 346 seems to compare with the top of 347 ; more detailed quantitative analysis is needed to check this correlation.

\section{Nannoplankton}

Nannofossils were found only in Core 1 to Core 2 (0$128 \mathrm{~m}$ ); below sediments are barren of nannoplankton. Coccolithus pelagicus becomes very frequent, and is the only species in thin nannofossil ooze layers. Emiliania huxleyi and Gephyrocapsa ericsonii are present in Core 1, Section 2. Cyclococcolithus leptoporous was observed sporadically. The amount of reworked Cretaceous and Eocene species is very low.

In Core 2, Section 2 and Core 3, few specimens of Reticulofenestra cf. umbilica, Zygolithus dubius, and Discolithina sp. were found indicating a middle to lower late Eocene age $(121-137.5 \mathrm{~m})$.

\section{Diatoms (H.-J.S.)}

All samples studied were barren in diatoms.

\section{Radiolarians}

This site can be regarded as being barren of radiolarians and other siliceous microfossils. Only in Sample 1, CC was a relatively rich, well preserved, modern radiolarian fauna obtained, dominated by Amphimelissa setosa, Pseudodictyophimus gracilipes, Cromyechinus borealis, and Spongotrochus glacialis.

Palynology (S.B.M.)

\section{Dinocysts}

Cysts are very rare throughout. Core 4 , Section 2 contains an assemblage with Deflandrea phosphoritica, Phthanoperidinium amoenum, and a few more of the species occurring in the interval 10-2 to 6-2 of Site 349 (Zone IV-V), only preservation is not so good.

\section{Debris, Reworked Material}

Carbonized tracheidal and resinous matter dominate preparations of Core 4, Section 2 and Core 3, Section 3, a few badly corroded cuticle fragments are also present. In the same preparations, all pollen and cysts appear to have suffered slight to moderate thermal alteration. At 
the present time, it cannot be decided whether this is indigenous material altered in situ, or if it is reworked.

In Core 2, Section 1, debris consists of tracheidal matter altered to varying degrees, and corroded cuticle fragments, particle size fairly small $(<100 \mu \mathrm{m})$. The pollen is thermally altered and appears reworked; cysts are poorly preserved and undiagnostic. Core 1, Section 2 has again different debris, consisting of carbonized tracheidal matter, some of it fairly large.

Unlike the situation in Holes 346 and 349 , there is no indication of any pre-Tertiary reworked material.

\section{BIOSTRATIGRAPHY, SITE 349}

\section{Biostratigraphic Summary}

Generally sediments of this hole are poor in microfossils. Pleistocene sediments were recovered in Core 1 and in the upper part of Core 2 with few nannofossils, Globigerina pachyderma, and few benthonic foraminifera. Diatoms and radiolarians are present only in Core 1. Sample 2, CC is rich in sponge spicules, and some fragments of Bathysiphon sp. were found, indicating a Miocene age.

Determination of middle Oligocene for Core 3 and Core $4(91.5-110.5 \mathrm{~m})$ is based on dinoflagellates and foraminifera which are comparable with those from northwest Europe. The late Eocene age for Cores 5 to $13(110.5-319.5 \mathrm{~m})$ is based on nannofossils, foraminifera, dinoflagellates, and a poor radiolarian assemblage in Core 13.

\section{Foraminifera}

\section{"Glacial," Pleistocene, Cores 1 through 2, Section 3}

This interval is characterized by left-coiling Neogloboquadrina pachyderma. This is the only planktonic foraminiferal species found; it is abundant or common in Core 1 and Core 2, Section 1 and common at the top of Section 2 of Core 2. But the lower samples of this section are barren as is the sample from Section 3 (2-3, $35-37 \mathrm{~cm})$. The barren lower levels are included in this interval because of the abundance of ice-rafted material: unsorted quartz, rock fragments (common basalt), (few) Cretaceous Inoceramus prisms, and (rare) shallow water pelecypods.

In most of the 17 samples Islandiella teretis is the predominant species of the benthonic fauna. Melonis zaandamae and "Cibicides" wuellerstorfi also are common whereas in some samples Bulimina aculeata comes second. This site differs from most others in the rather common presence of Nodosariacea (Marginulopsis linearis, Dentalina frobisherensis, D. pauperata) and of arenaceous species of the genera Psammosphaera, Tolypammina, and Rhabdammina. Other benthonic species present are: Pullenia bulloides, Eponides umbonatus, Quinqueloculina sp., and (probably ice-rafted) Elphidium sp. and Cibicides lobatulus.

\section{Undiagnostic (Pliocene?), Core 2, Section 4 to Sample 2, CC}

Washed residues of all samples (two from each section) consist largely of glauconite (with a bit of volcanic glass) and were barren of foraminifera. The samples have some sponge spicules, radiolarians, and diatoms; spicules are abundant in 2, CC. One fragment of Bathysiphon sp. was found in the core-catcher sample. Section 6 and the core-catcher sample in addition have quartz and rock fragments which could have been added by mixing during the coring but which may also represent an earlier period of ice-rafting. Mixing seems to be the more plausible explanation, although it could be argued that such should not be restricted to the lowermost barren part of the "glacial" section and hence that $N$. pachyderma should have been present as well.

\section{Oligocene, Cores 3 through 5, Section 5}

This interval is practically barren of foraminifera. Its Oligocene age is based on a benthonic calcareous fauna found in Samples 3, CC and 4-1, 95-97 cm: Angulogerina gracilis, Turrilina alsatica, Sphaeroidina bulloides, Eponides pygmeus, Cibicides sp., and Oolina sp. (cf. Sites 336 and 338); "middle" or "lower" Oligocene of Batjes, 1958; Dinesen, 1959; Drooger, 1969; Ulleberg, 1974. Samples 4, CC and 5-1, 30-32 cm have very rare arenaceous tests of Eggerella sp., Bathysiphon sp., and Spirosigmoilinella sp. Spicules are common; Sample 3, CC has abundant pyritized spicules and lumps of sponge skeleton of exceptional beauty.

The Oligocene washed residues are rather large and consist of quartz sand with chert and other rock fragments and some light gray ash or pumice. The sand is as heterogeneous as the ice-rafted material but differs in that many grains have a polished brilliance, in being somewhat better sorted, in the absence of basalt and Inoceramus, and in the rather common presence of bipyramidal quartz grains. Pyrite is found in most samples. The base of this unit lies between Samples 5-6, $120-122 \mathrm{~cm}$ and $5-6,142-144 \mathrm{~cm}$ and is marked by a change in compaction that has been interpreted to signify an unconformity.

\section{Upper Eocene, Core 5, Section 6 through Core 13}

The washed residues are much smaller below the "unconformity" than above it, but not richer in fossils. Of 56 samples 27 are barren, 11 have one or a few calcareous specimens, and eight have an arenaceous foraminiferal fauna. The best calcareous fauna was recovered from Sample 10, CC: Cancris subconicus, Alabamina wolterstorfi, Bulimina ovata, Guttulina problema, Glandulina laevigata, Dentalina ewaldi, Nodosaria minor, and Gyroidina sp. A quite different assemblage is found in 11, CC: Globobulimina sp., Allomorphina sp., and Chilostomella tenuis, which resembles the association from 6, CC with the same Globobulimina sp. and Allomorphina sp. but with Uvigerina cf. spinicostata. Sample 13, CC has Lagena isabella. Of the very few calcareous fossils that were found outside the core-catcher samples, most are indeterminable fragments. An exception is Cancris subconicus in Sample 6$6,48-50 \mathrm{~cm}$. Arenaceous species found are Spiroplectammina spectabilis (highest in 10-3, 25-27 cm), Textularia sagittula, Cyclammina sp., Cribrostomoides sp., Haplophragmoides sp., Psammosphaera sp., Tolypammina sp., and Rhabdammina sp. They can be rare to common, but, unlike what we found at some other 
sites, they never occur in abundance. Some or all of these assemblages seem to be displaced, originating from different parts of the shelf or upper slope. Redeposition is further suggested by the presence of coaly and/or pyritized wood fragments, and in 10, CC also by echinoid and bryozoan skeletal remains. Altogether the fauna is quite typical for the northwest European upper Eocene (Kaasschieter, 1961; Bettenstaedt et al., 1962; Drooger, 1969).

A further characteristic of this unit is the presence of large pyritized and/or recrystallized diatoms (Triceratium and a compressed Cerataulus-like form), they were found as high as Sample 6-3, 40-42 cm, as low as $13-1,108-110 \mathrm{~cm}$, and are abundant in some samples of Core 7.

The main constituents of the washed residues are sand (as described for the Oligocene) and pyrite which can vary in relative abundance to the extremes that some samples have nothing but sand and others only have pyrite. Some levels have corroded volcanic glass.

\section{Nannoplankton}

Sediments recovered at Site 349 are extremely poor in nannoplankton. In Cores 1 and $2(0-63 \mathrm{~m})$ Coccolithus pelagicus, Cyclococcolithus leptoporus, Helicosphaera carteri, Gephyrocapsa ericsonii, and reworked species of the Cretaceous and Eocene were found.

Cores 3 through $5(91.5-120 \mathrm{~m})$ are barren of nannoplankton. In Samples 5-6, 148-149 cm to $12-4,84-85 \mathrm{~cm}$ $(110.5-272 \mathrm{~m})$ an assemblage was observed indicating a late Eocene age. Only few nannofossils are present in some horizons of this interval, and they are slightly etched. The assemblage consists of Isthmolithus recurvus, Reticulofenestra umbilica, Dictyococcites dictyodus, Cyclococcolithus floridanus, Braarudosphaera bigelowi, Cyclococcolithus luminis, and Cribrocentrum reticulatum. Discoasters are missing in the Eocene sequence.

\section{Diatoms (H.-J.S.)}

The only sample with diatoms came from Sample 1$1,70-72 \mathrm{~cm}$ and contained a well-preserved diatom assemblage with sponge spicules and ash shards in rare abundance. The occurrence of Thalassiosira kryophila, $T$, oestrupii, $T$. gravida placed this sample into the Thalassiosira oestrupii Partial Range Zone, and is 0-1.8 m.y. old. All other samples were barren in diatoms.

\section{Radiolarians}

Radiolarians were recovered from the top and bottom of this hole, and three units can be identified.

Unit 1 (Core 1) has abundant radiolarians in a sample $10 \mathrm{~cm}$ below mudline, but few are present in Sample $1, \mathrm{CC}$ at a depth of 6 meters. The fauna assemblage recovered is typical of that found in the Norwegian Sea sediments today.

Unit 2 (Cores 2 through 12) is barren of radiolarians. Sample 2, CC is rich in sponge spicules, but they are for the most part fragmented and often strongly corroded. The spicule morphotypes can be correlated with the morphotype assemblage recovered from Sample 6, CC at Site 346, indicating an early-middle Miocene age.
Unit 3 (Core 13) is characterized by a low content of siliceous microfossils. However, one radiolarian species, Antarctissa sp., was found. The latter was also found in the Calocyclas talwanii Zone at Site 338, indicating a late Eocene age.

Palynology (S.B.M.)

\section{Dinocysts}

A workable cyst assemblage was recovered only from Core 3, Section 2, above the unconformity. Other samples were barren or with few cysts.

The Core 3, Section 2 sample contains a Zone III assemblage identified by the following species: Impletosphaeridium sp. I, Hystrichokolpoma rigaudae, Operculodinium cf. centrocarpum, Problematicum III, and Leptodinium sp. II.

Samples from Core 6, Section 2 to Core 10, Section 2 have infrequent cysts indicative of Zone IV to V. Deflandrea phosphoritica and Phthanoperidinium amoenum are consistently present; other stratigraphically significant species are cf. Gonyaulacysta giuseppei and Homotryblium sp. I. Cyclonephelium ordinatum and C. reticulosum are also present; at Site 338 they are present as rare species only in Zone VIIa, but have been seen elsewhere in Zone IV-V assemblages.

\section{Debris, Reworked Material}

Terrestrial plant debris dominates all preparations. In Core 13, Section 2 to Core 6, Section 2, it consists of slightly altered cuticular and tracheidal matter. Pollen and spores are slightly altered and of early Tertiary age when diagnostic. In Core 13, Section 2, reworked cysts (Ctenidodinium $\mathrm{cf}$. elegantulum) of Lower Cretaceous age are present.

In Core 3, Section 2 debris is different, containing more carbonized tracheidal matter and having a more thermally altered appearance. A few reworked cysts of a mid- to Late Cretaceous age (Deflandrea spp.) are present.

The glacial cores contain carbonized tracheidal matter and very little else.

\section{SUMMARY AND CONCLUSIONS-SITES 346 AND 347}

\section{Summary}

"Glacial" sediments are present to a depth of about 25 meters at Site 346 . They consist of terrigenous sandy mud with minor amounts of terrigenous mud and clay. Among the planktonic foraminifera, only the leftcoiling $G$. pachyderma was observed. Benthonic fauna has a low diversity and deep water character. Radiolarians and nannofossils are scarce.

Middle Miocene to Oligocene (?) sediments seem to extend in a single unit from about 32 meters to about 120 meters. This unit consists of sandy mud and biogenic siliceous oozes that are characterized by a very high percentage of sponge spicules, especially in the lower part of this unit. Coarse clastic material, including pebbles, continues to be present in the Miocene, and the possibility of ice rafting as a source of debris cannot be ruled out. Radiolaria, silicoflagellates, 
and some siliceous foraminifera are present in the top part of this unit, that is, in the middle Miocene. However, the lower part of this unit is, with the exception of sponge spicules, almost completely barren. The age of Oligocene (?) for the lower part of the section comes from a few corroded calcareous benthonic foraminifera, supported by dinoflagellates.

There is an important unconformity at about 120 meters, below which there is a sedimentary unit of Eocene age. This unit consists primarily of massive, terrigenous sandy mudstone, and locally grades into sandstone and mudstone. It was quite difficult to penetrate this unit, and it took almost as long to core it as it often takes to core basalt. Turbidite layers often are present in the lower part of this unit. This unit is barren except for arenaceous benthonic foraminifera and a few badly preserved calcareous foraminifera. An upper Eocene age is tentatively assigned to the fauna from Hole 347.

A calculation was made from measured velocities on core samples and compared with the travel time observed on the reflection profiler record.

Average velocity for the samples from lithologic Units 1 and 2, Cores 1-13, 0-121.8 m (Site 346) is 1.565 $\mathrm{km} / \mathrm{sec}$. Calculated travel time is $0.156 \mathrm{sec}$. This compares well with observed travel time of about $0.16 \mathrm{sec}$ with the prominent unconformable reflector (Figure 2).

\section{Conclusions and Discussion}

A few points, which are included in this final discussion, are noted below:

1) From faunal evidence, as well as from the presence of trubidites, a deep water origin is suggested for the basal Eocene unit. The sediments have been uplifted since their deposition.

2) If the Norway Basin stopped spreading about 30 m.y. ago, these sediments cannot have been deposited on younger oceanic floor. They either lie on older oceanic floor, or on continental basement (a complete lack of magnetic anomalies favors a continental basement). In either case, since younger ocean floor lies between Jan Mayen Ridge and Greenland, older sediments on Jan Mayen Ridge were deposited when it was attached to Greenland.

3) The sands in the Miocene sediments are harder to explain since new ocean lay between Jan Mayen Ridge and Greenland. They could have been obtained by erosion and redeposition of older sediments.

4) Many ash layers are present in the glacial sediments, and the possibility exists that they may have been derived from Jan Mayen Island.

\section{SUMMARY AND CONCLUSIONS-SITE 349}

The situation at Site 349 is somewhat similar to that at Sites 346 and 347. "Glacial" beds lie above Oligocene beds which were first cored at 91 meters below the sea bed. At Site 349, an unconformity at 120 meters is especially clear lithologically, since it is marked by a basal conglomerate. As for measured velocities on cores from Site 346 , calculated travel time of $0.16 \mathrm{sec}$ agrees with measurements from the seismic reflection profiler record (Figure 4). Below the unconformity lie early Oligocene or late Eocene beds; however, stratigraphically, they lie higher than the sediments at Sites 346 and 347. For instance, Spectabilis, which is found below 150 meters at Site 346 , is found below 300 meters at Site 349. More work is necessary to establish whether the entire section at Site 349 lies above the section at Site 346 , or whether there is an overlap, with a possible facies change between the two sites. The sediments are generally quite similar in lithology at the two sites.

The cores from Site 349 confirm the picture of the Jan Mayen Ridge as a feature with horizontal beds of late middle Oligocene age or younger, lying over an unconformity. Below this unconformity early Oligocene and older beds exist, dipping to the east.

Data from the youngest beds above the unconformity agree well with the date for the shift of the spreading axis from Norway Basin. The new spreading axis separated Jan Mayen Ridge from Greenland, thereby removing it from the immediate vicinity of a terrigenous sediment source.

\section{REFERENCES}

Batjes, D.A.J., 1958. Foraminifera of the Oligocene of Belgium: Verh. Kon. Belg. Inst. Natuurw., no. 143, 188 p.

Bettenstaedt, F., Fahrion, H., Hiltermann, H., and Wick, W., 1962. Tertiär Norddeutschlands. In Leitfossilien der Mikropaläontologie: Berlin (Publ. Borntraeger), p. 339378.

Dinesen, A.A., 1959. Vejle Fjord Formationens Foraminiferer: Geol. Surv. Denmark, II Ser., p. 61-99.

Drooger, C.W., 1969. Microfauna close to the Eocene-Oligocene boundary in the boring at Kallo: Toelicht. Verhand. Geologische kaart en Mijnkaart van België, no. 11, p. 938.

Kaasschieter, J.P.H., 1961. Foraminifera of the Eocene of Belgium. Verh. Kon. Belg. Inst. Natuurw., no. 147, $271 \mathrm{p}$.

Ulleberg, K., 1974. Foraminifera and stratigraphy of the Viborg Formation in Sofienlund, Denmark: Geol. Soc Denmark Bull., v. 23, p. 269-291. 

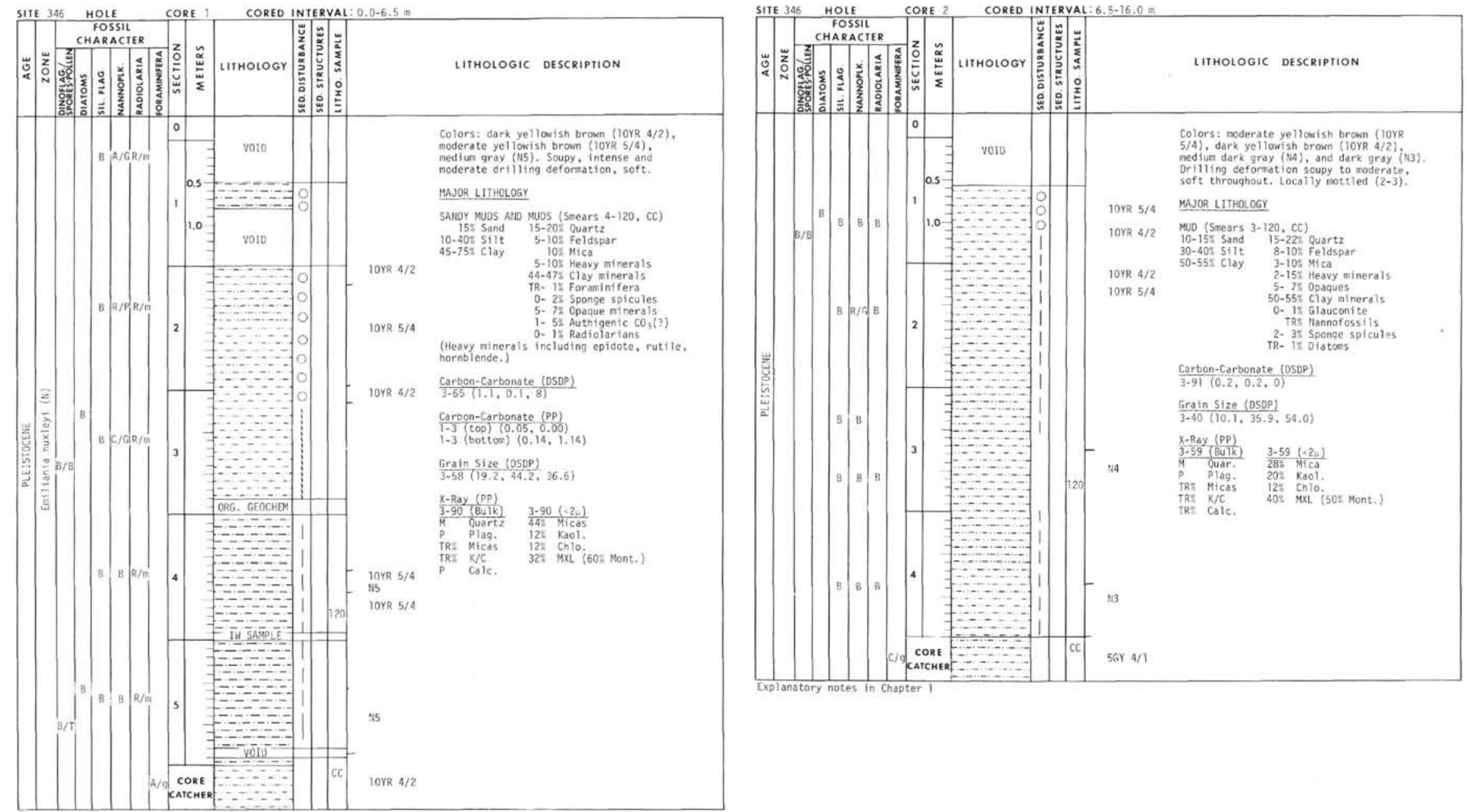

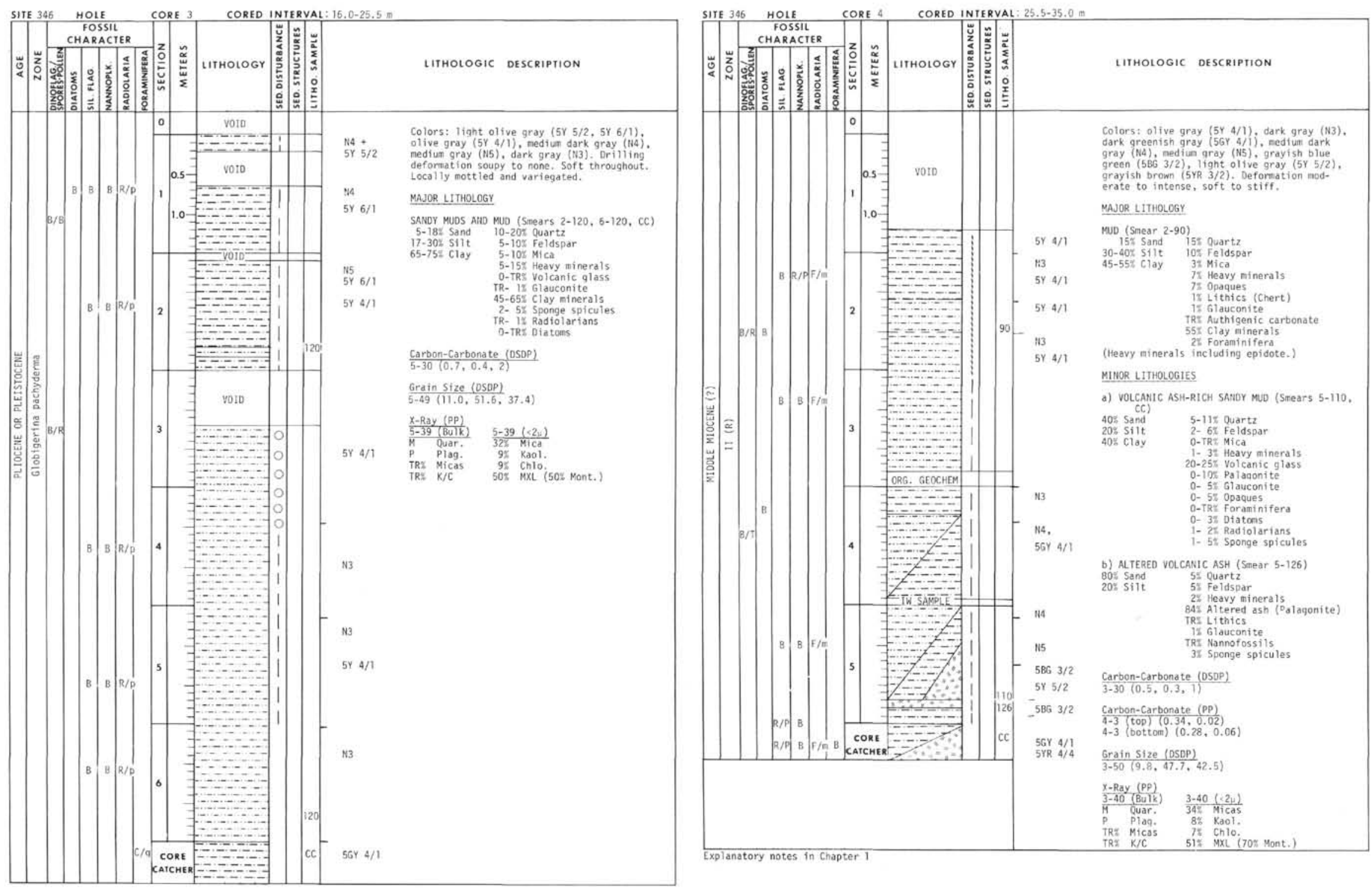


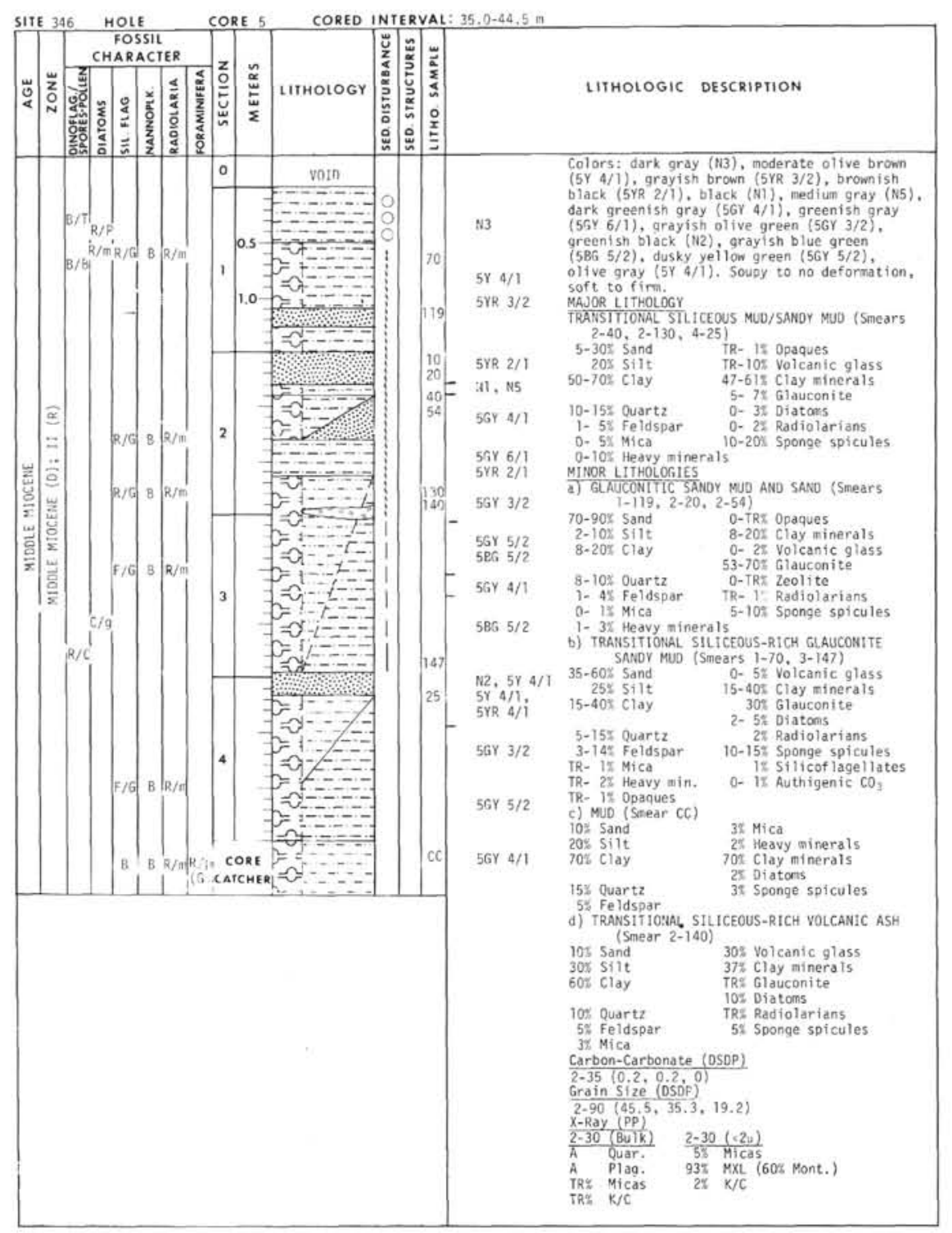

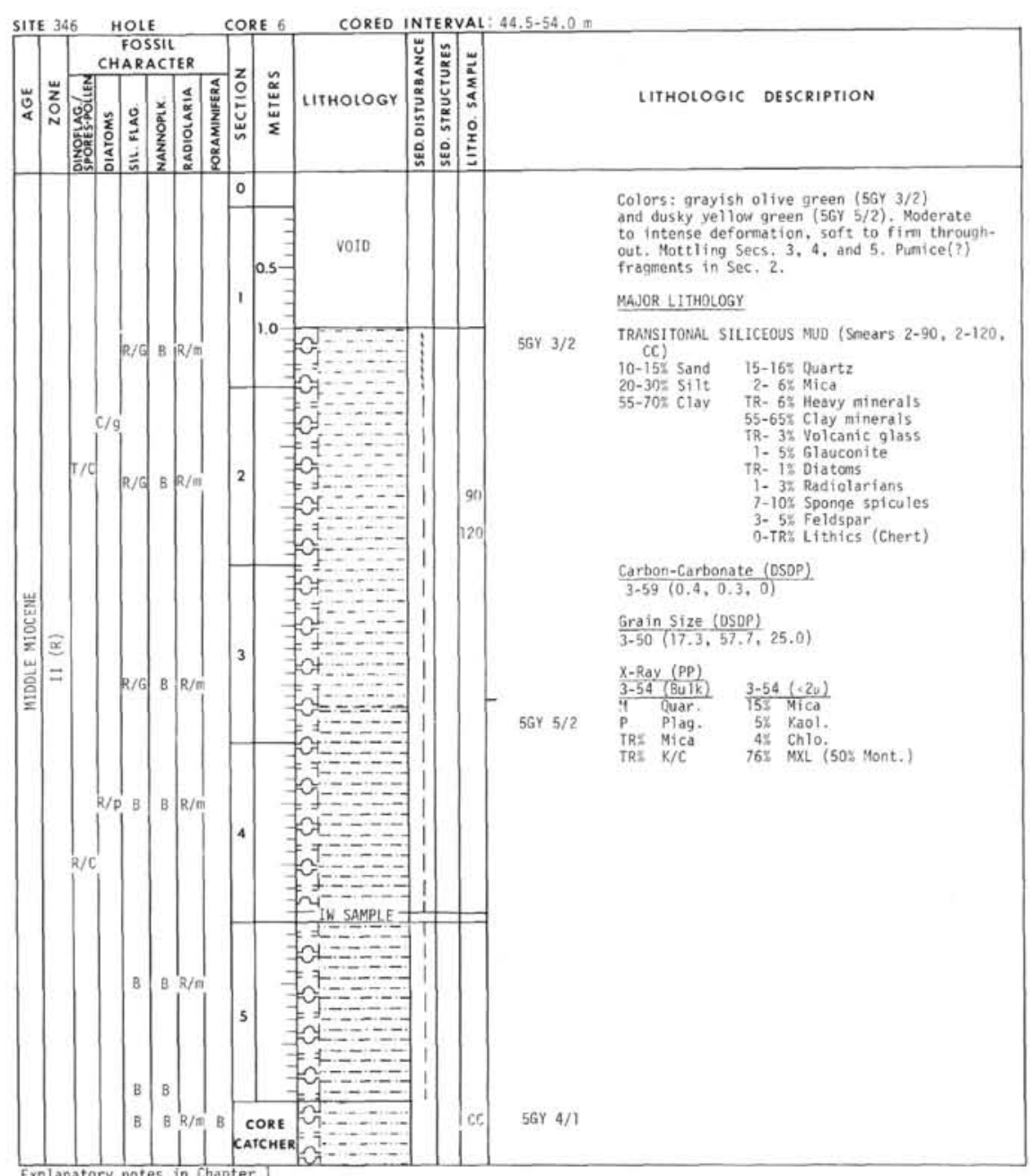




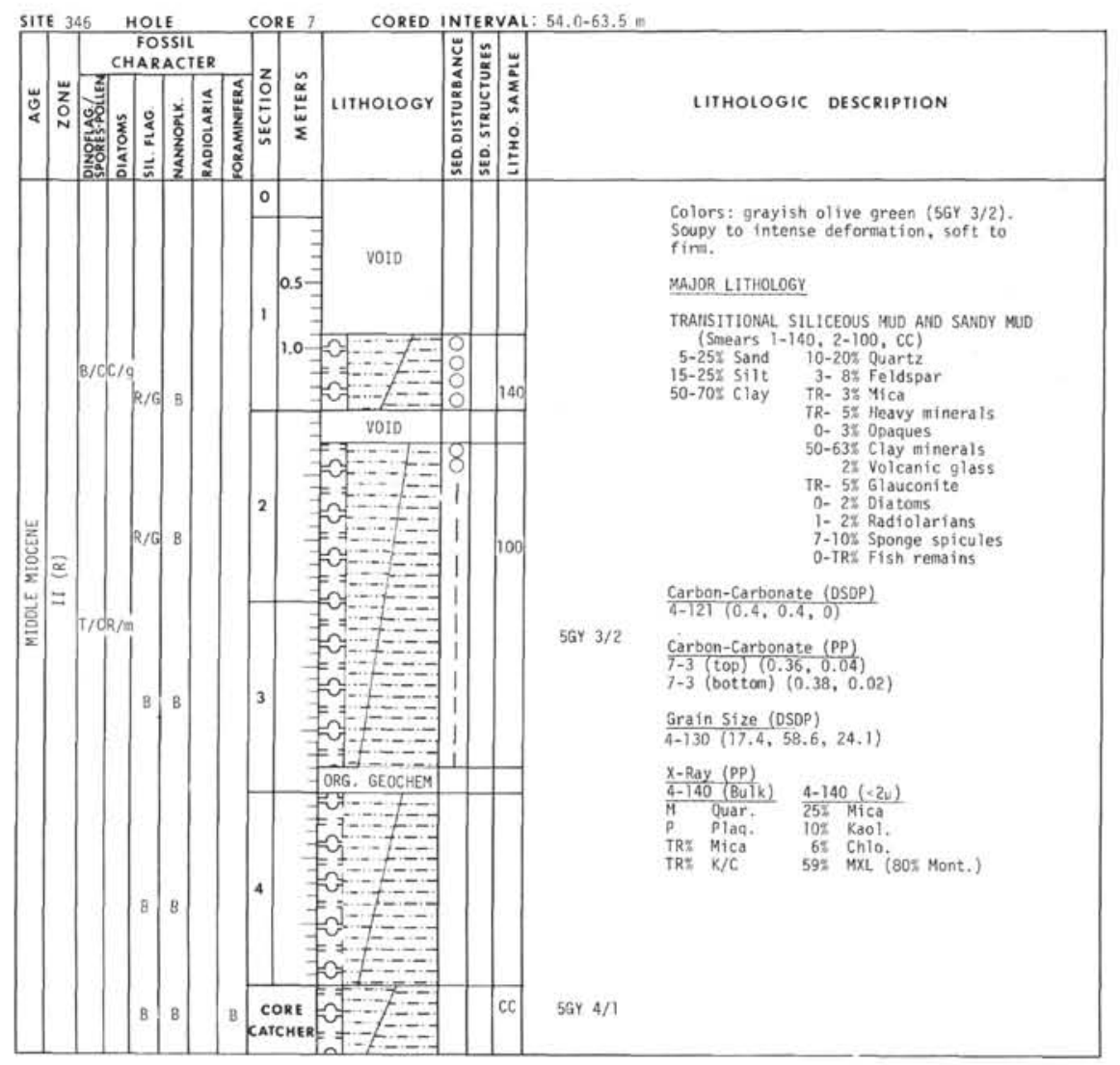

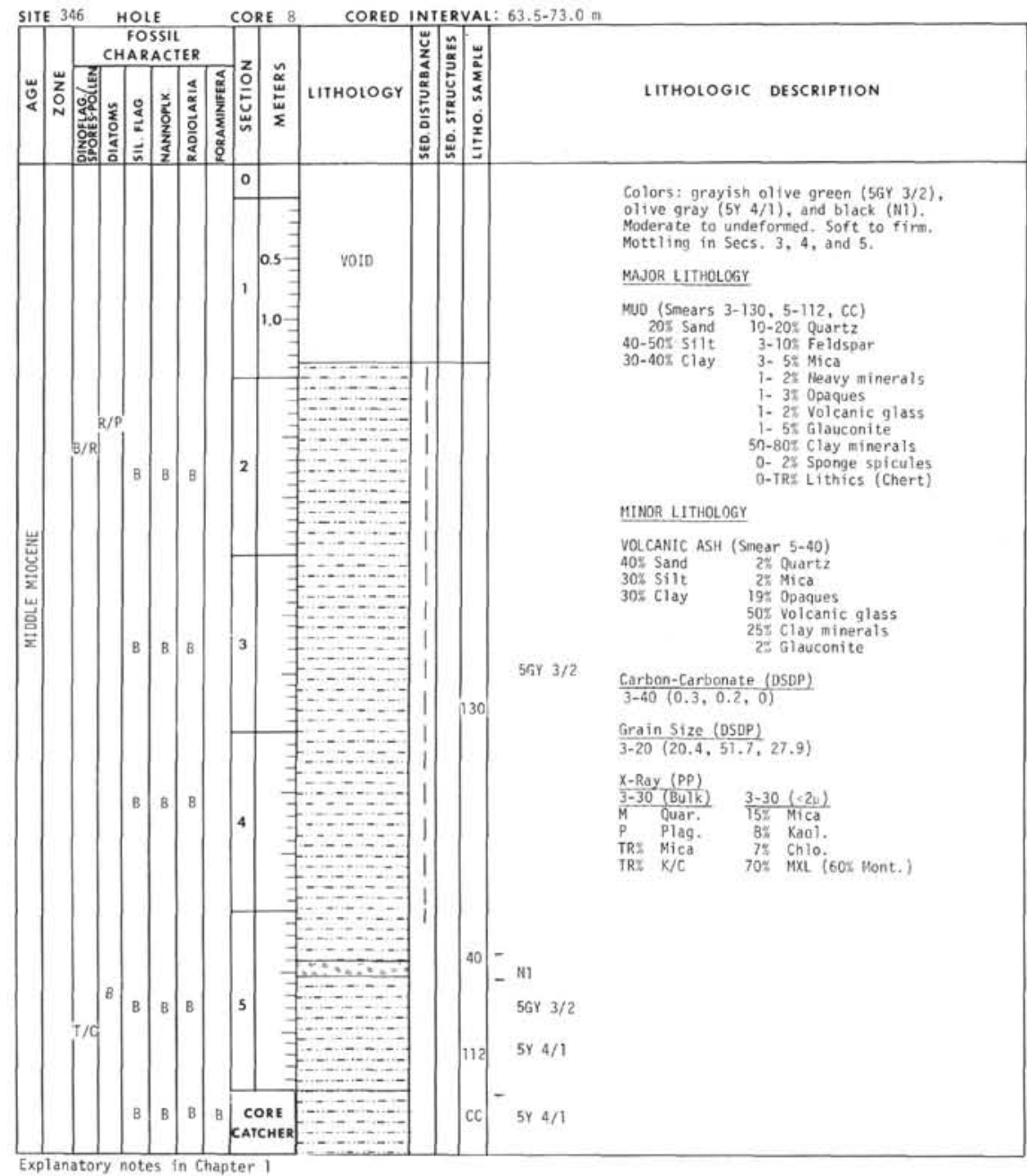



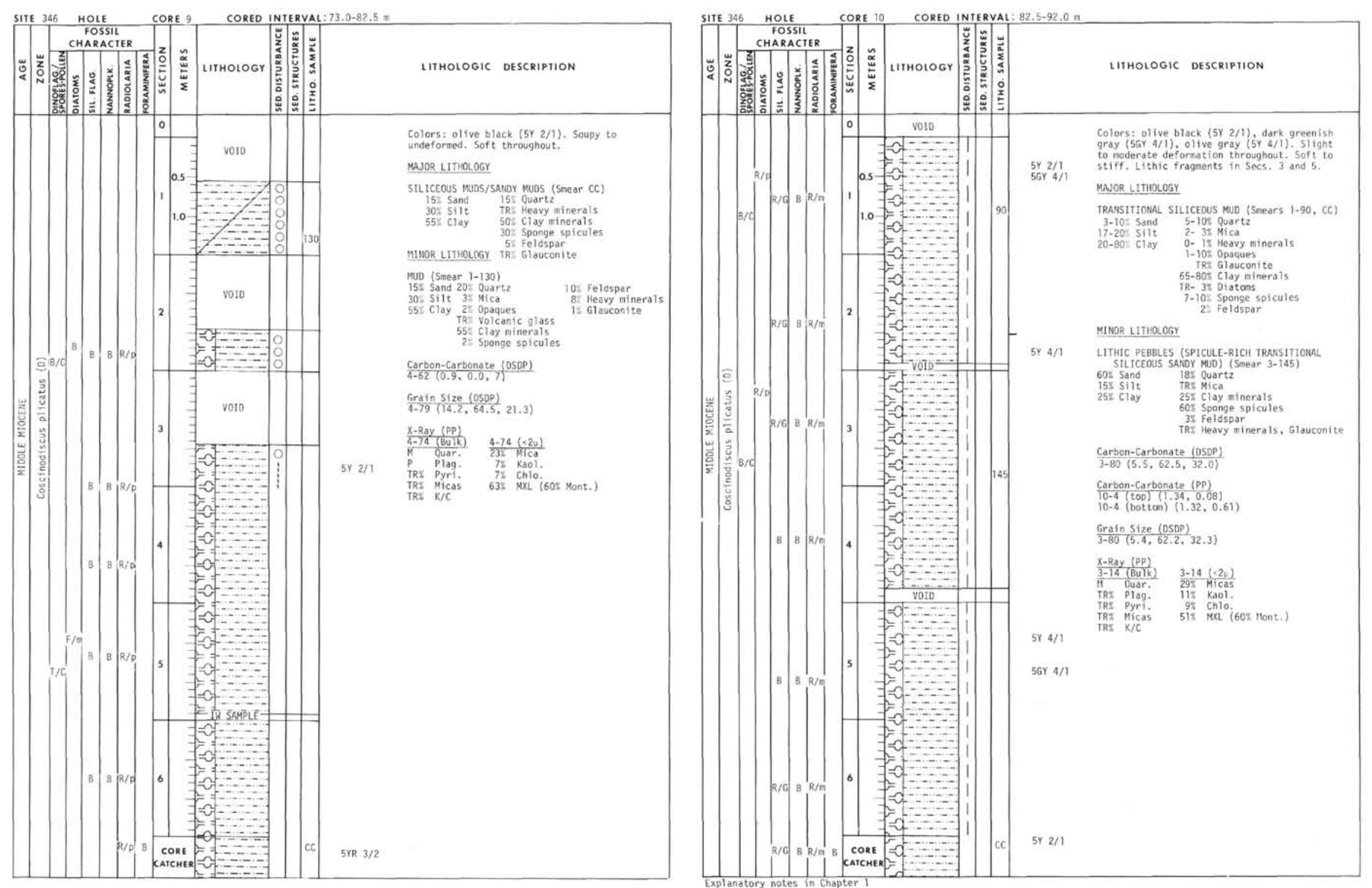


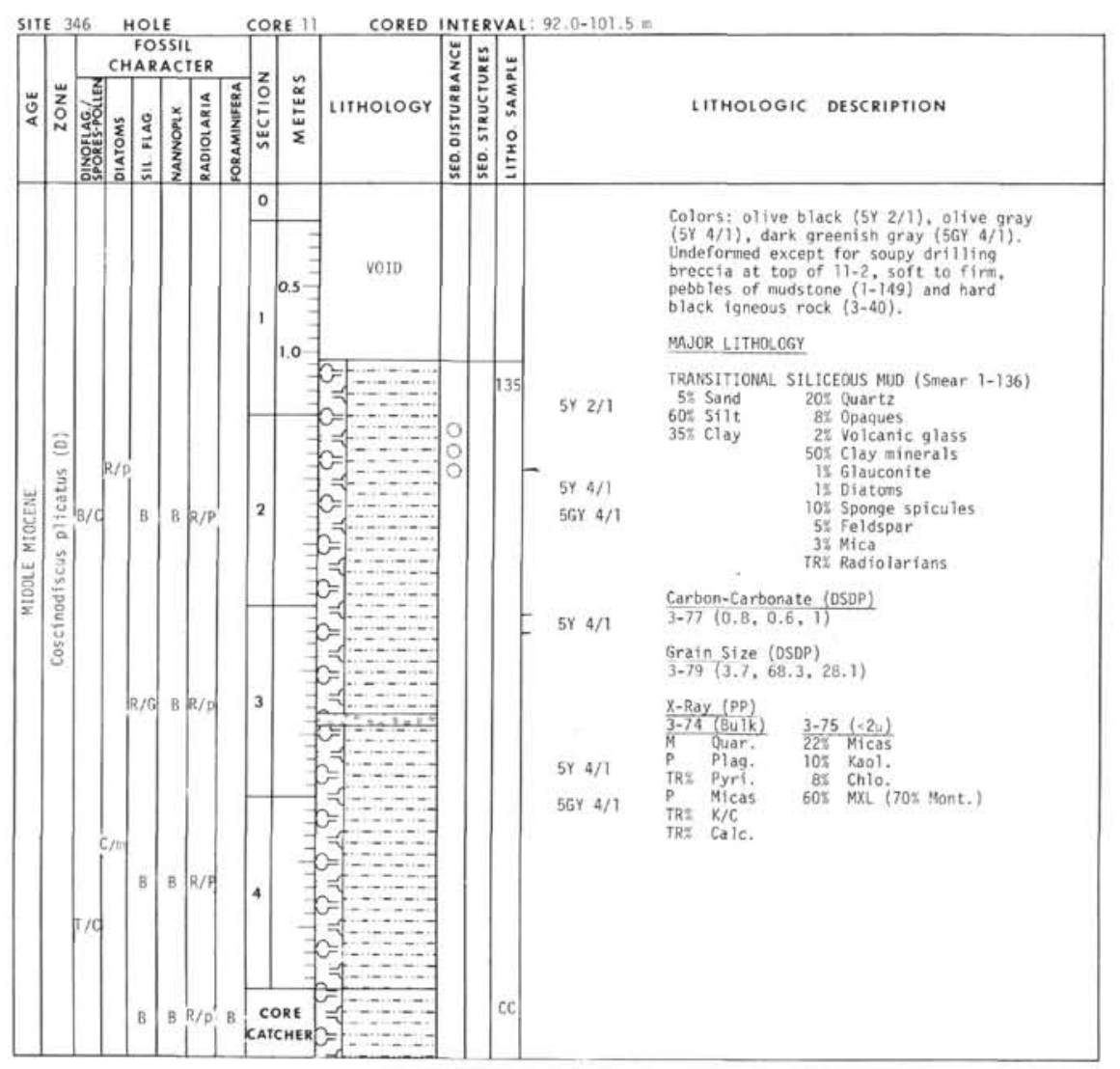

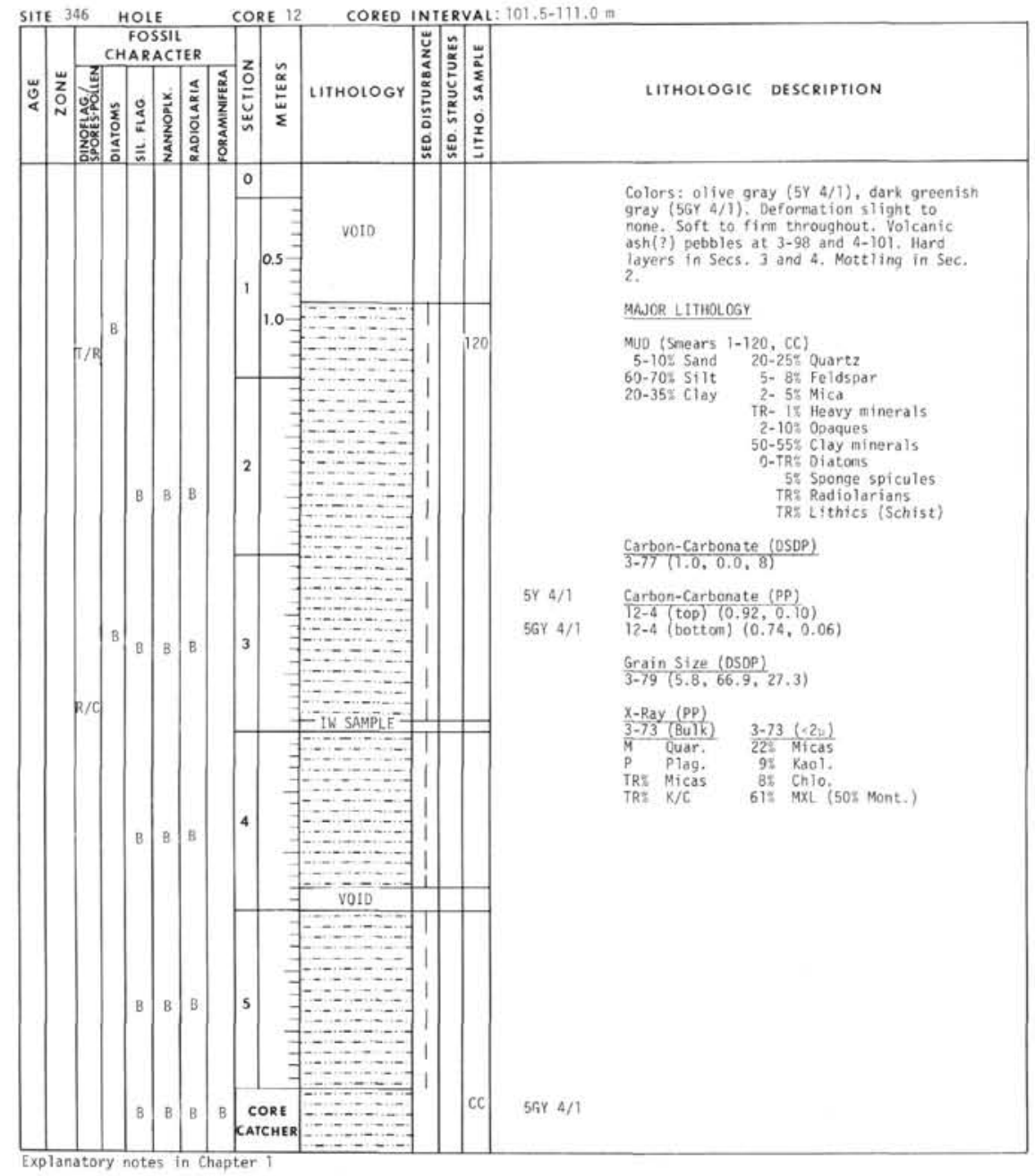




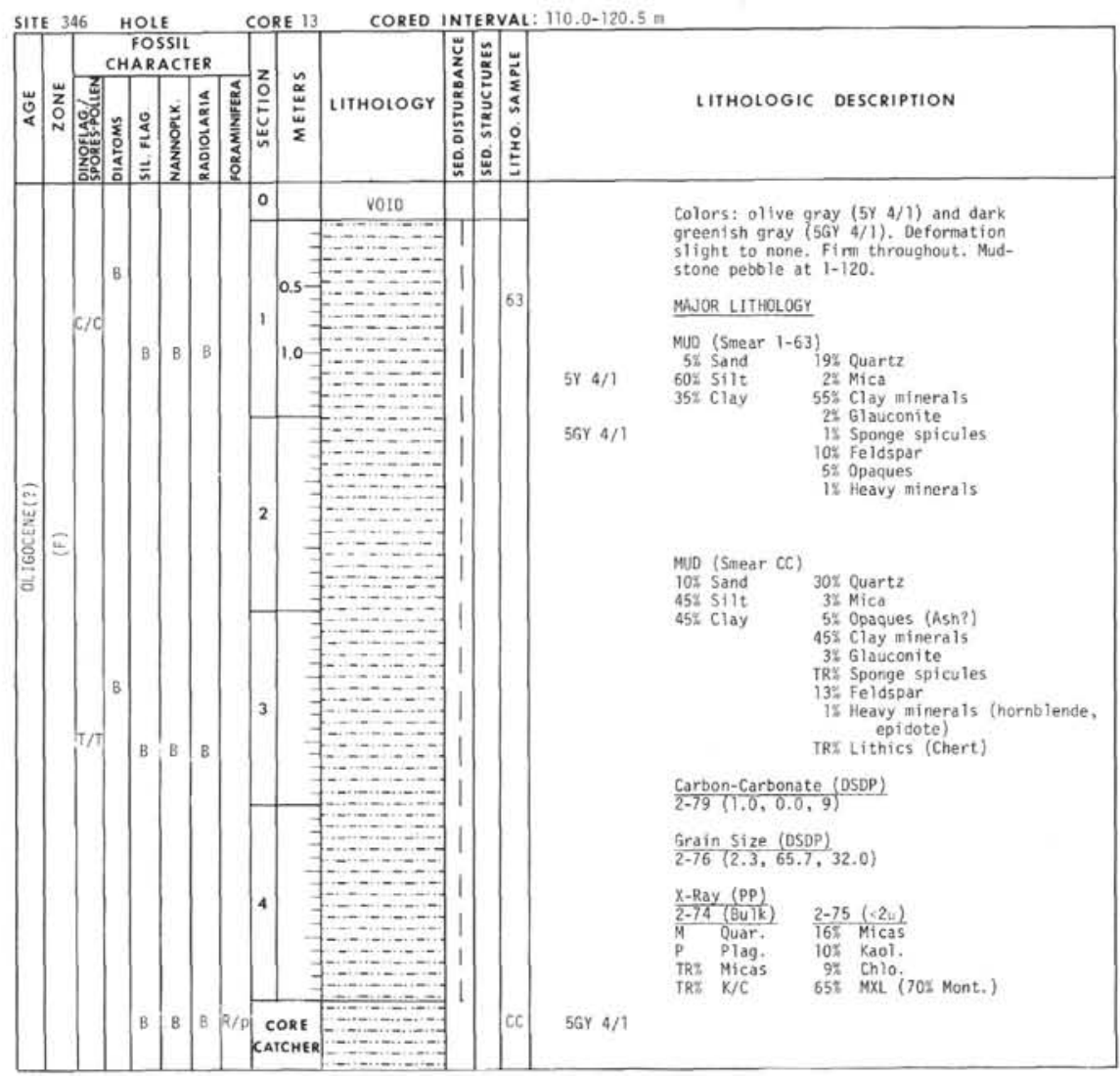

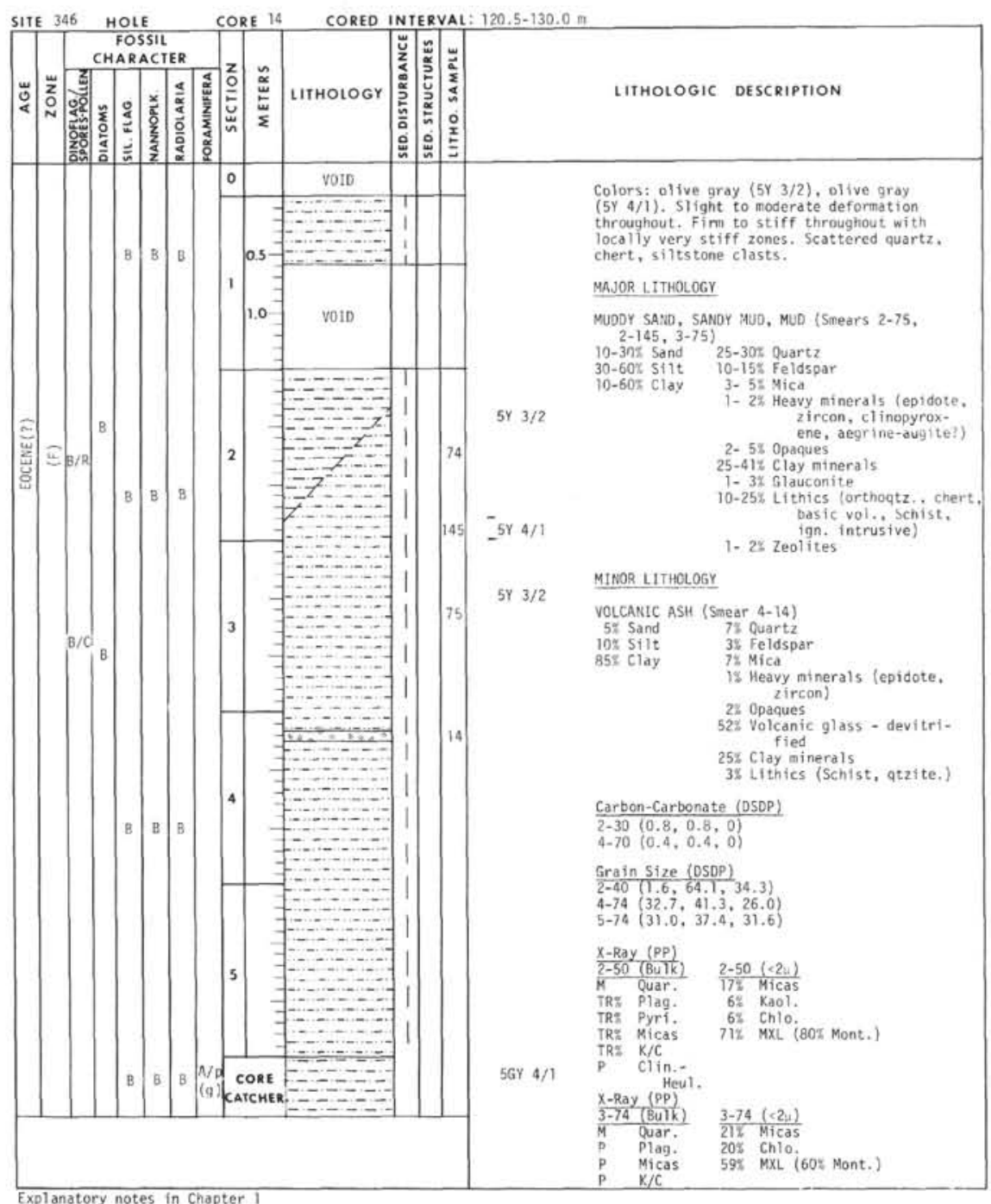




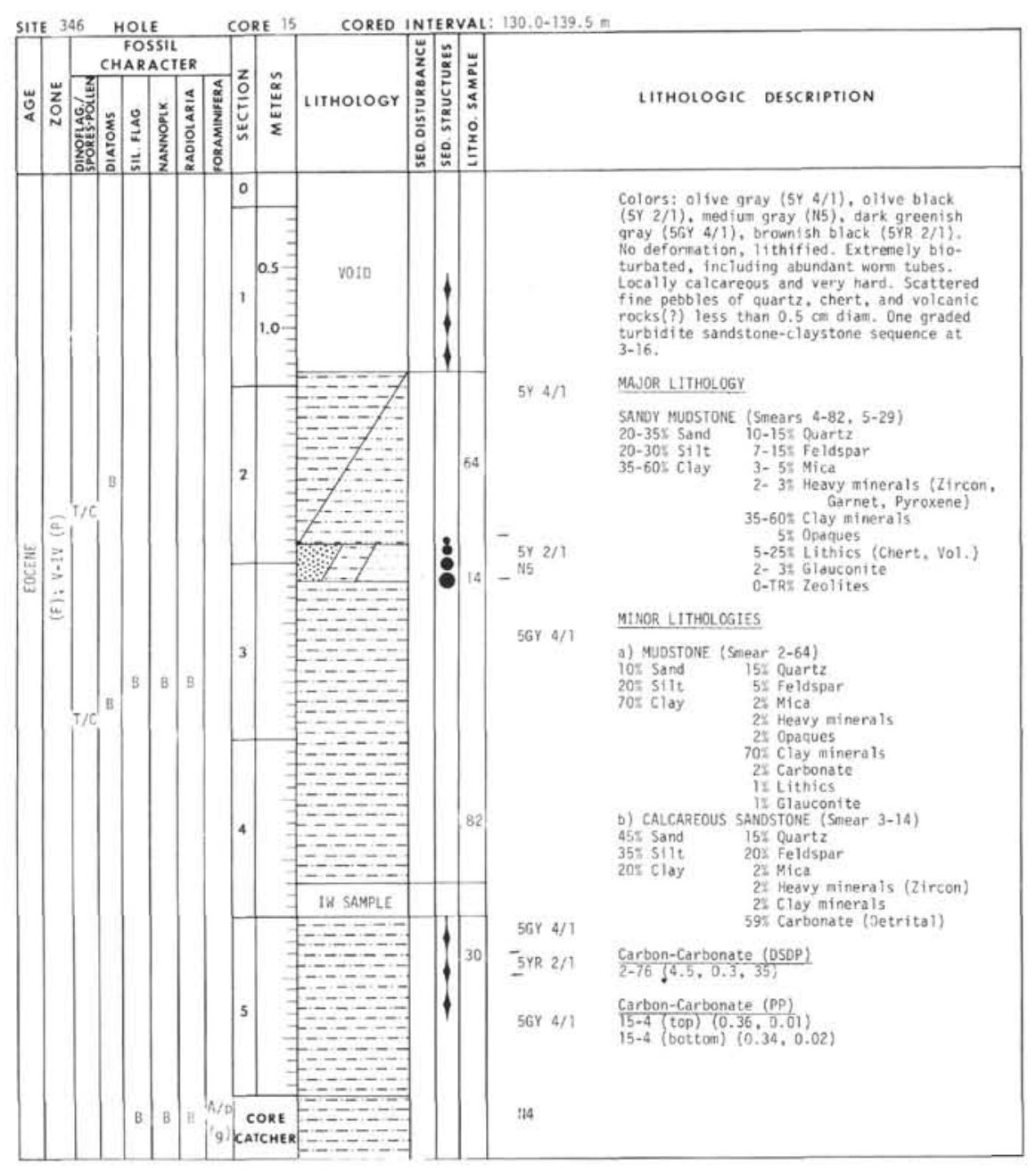

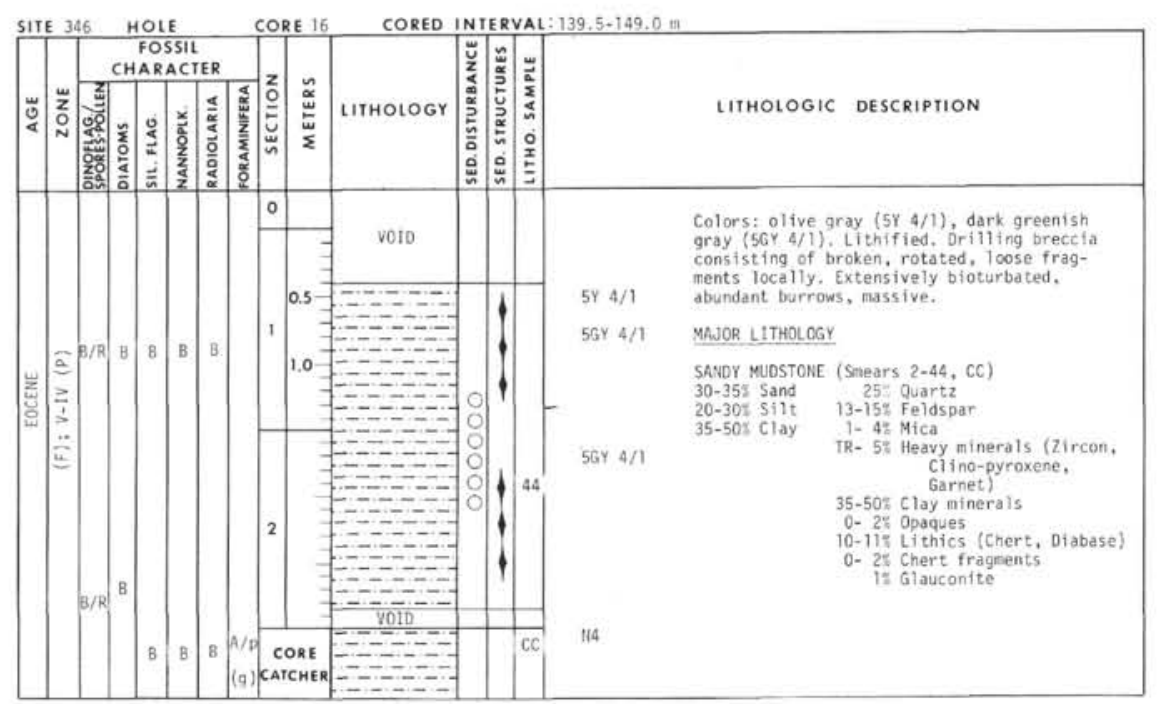

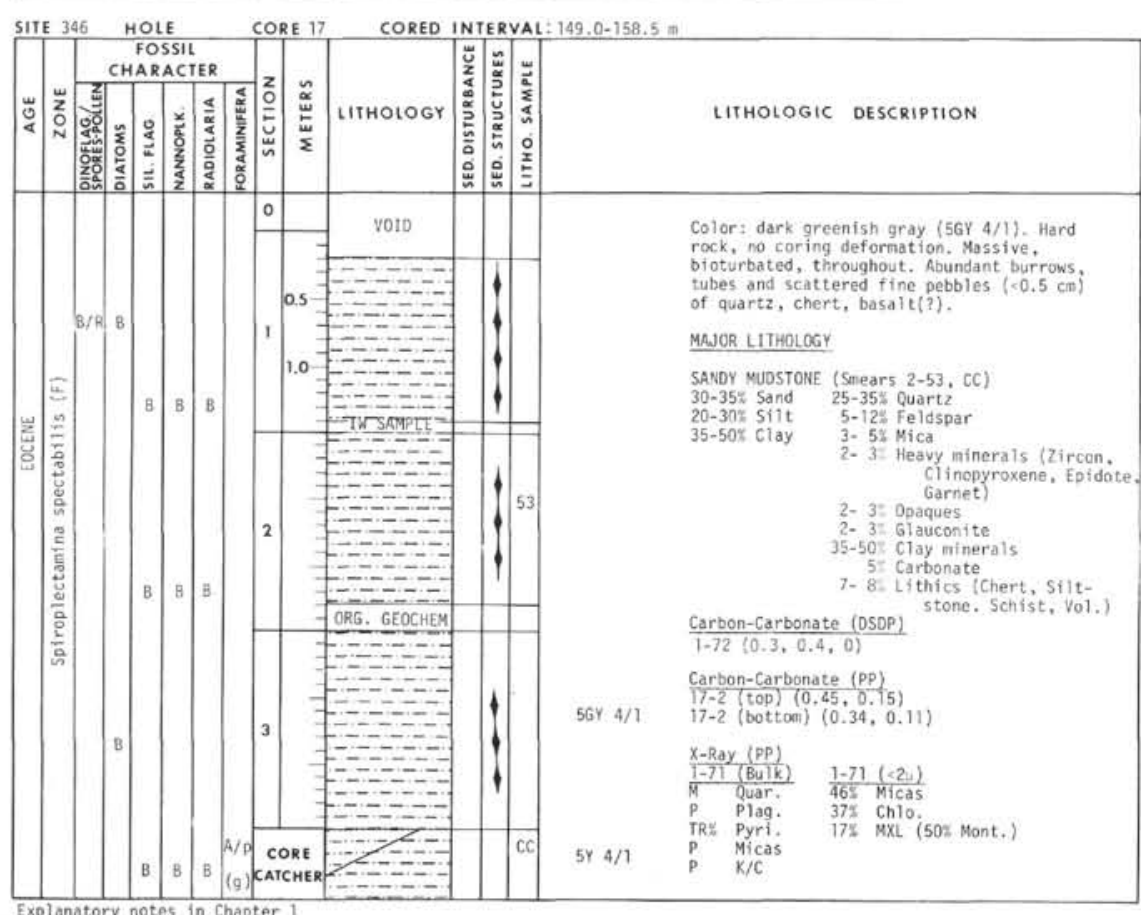

Explanatory notes in chapter 1 


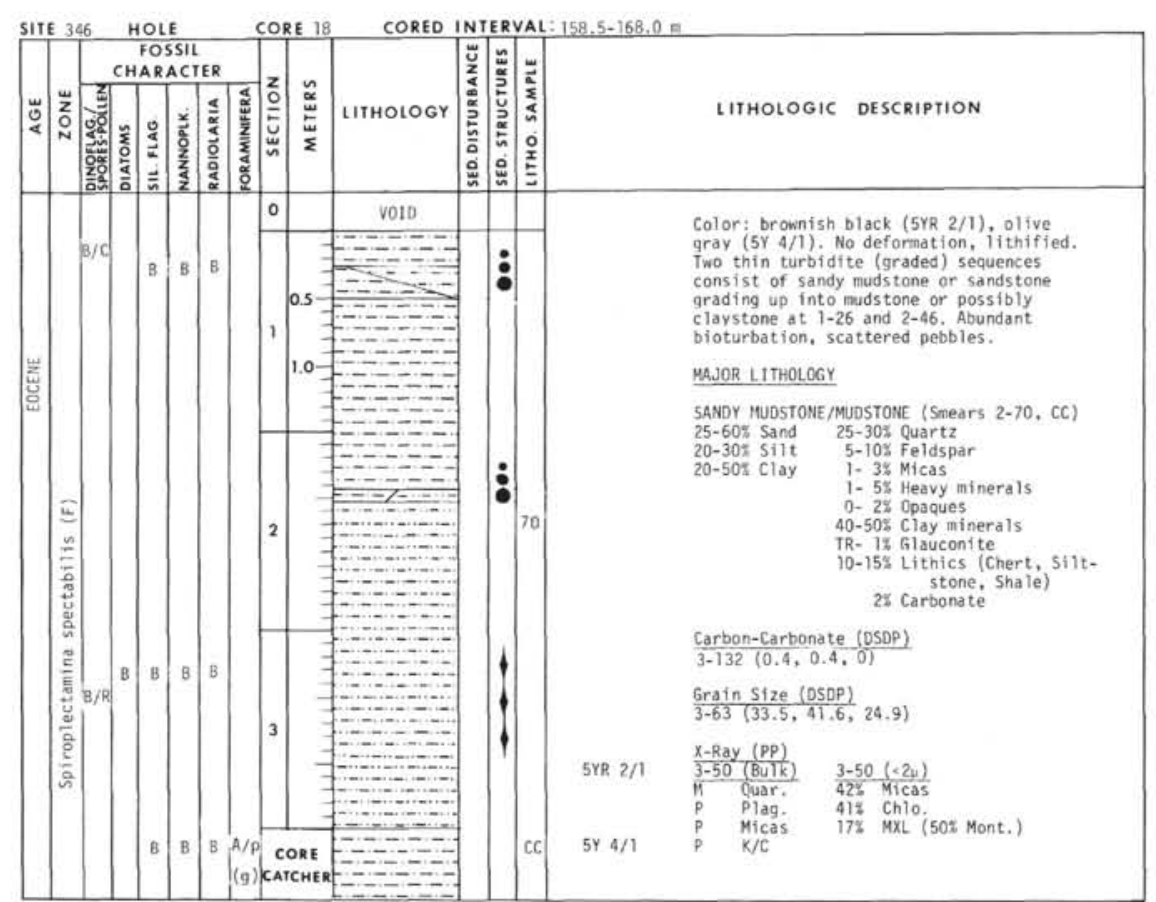

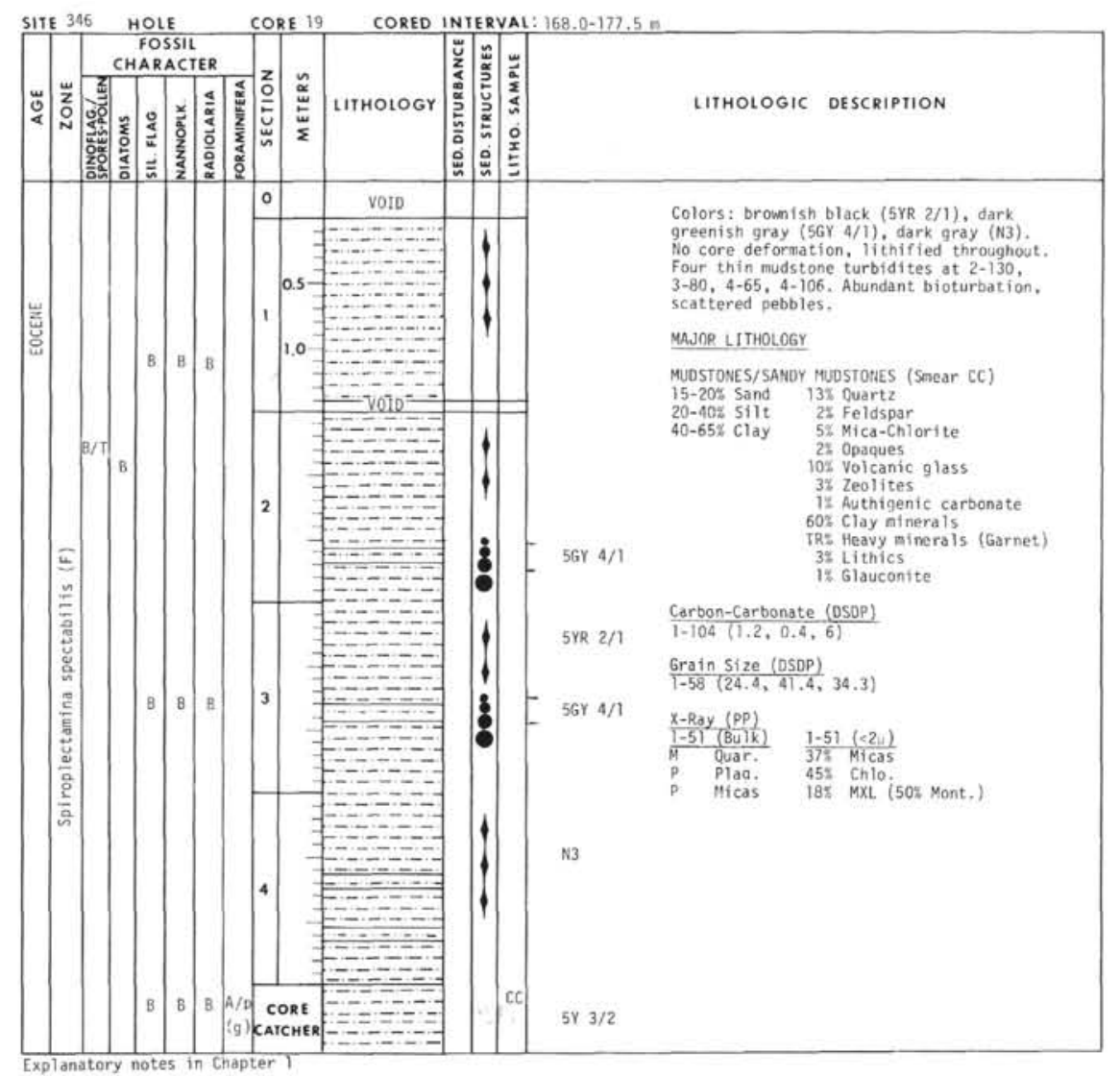




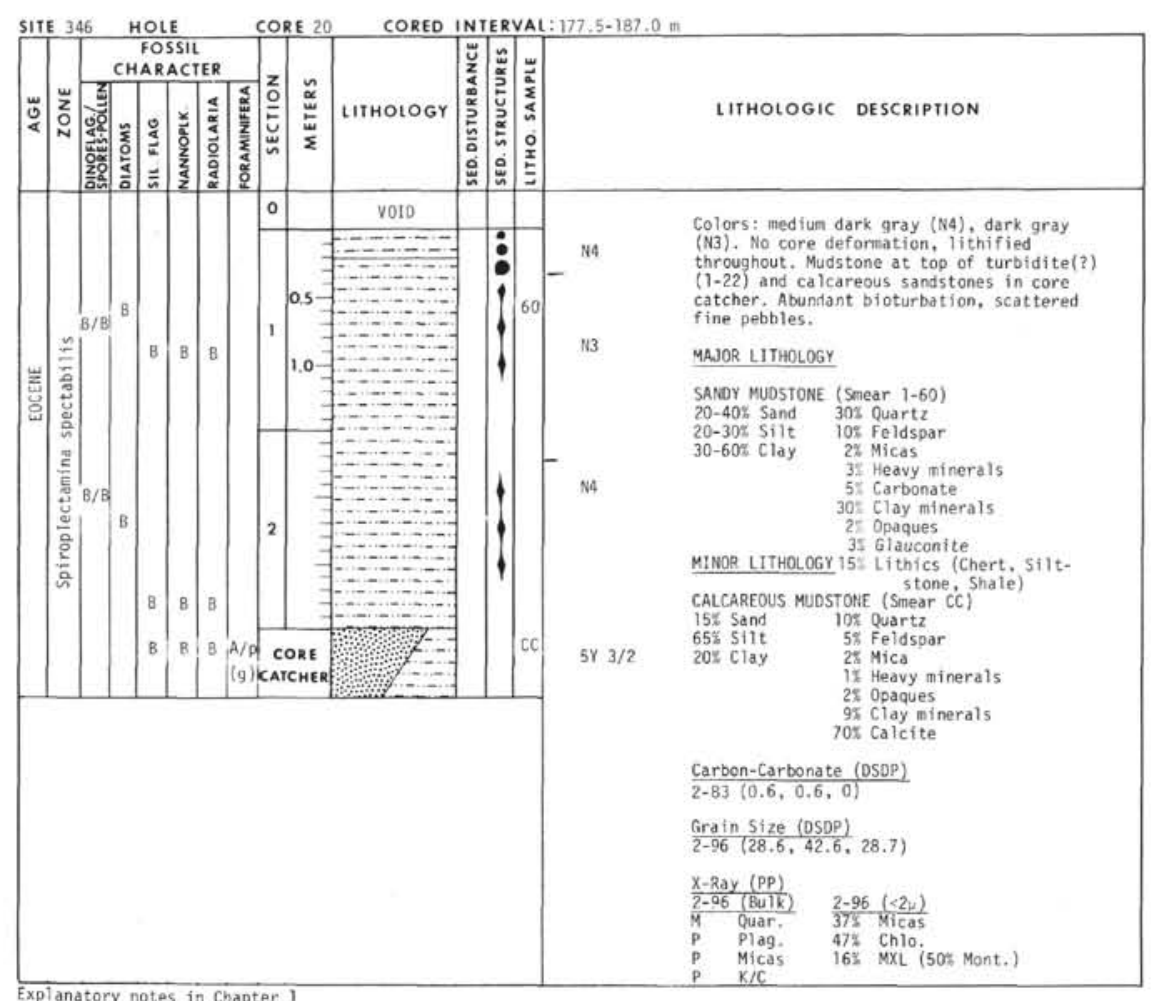




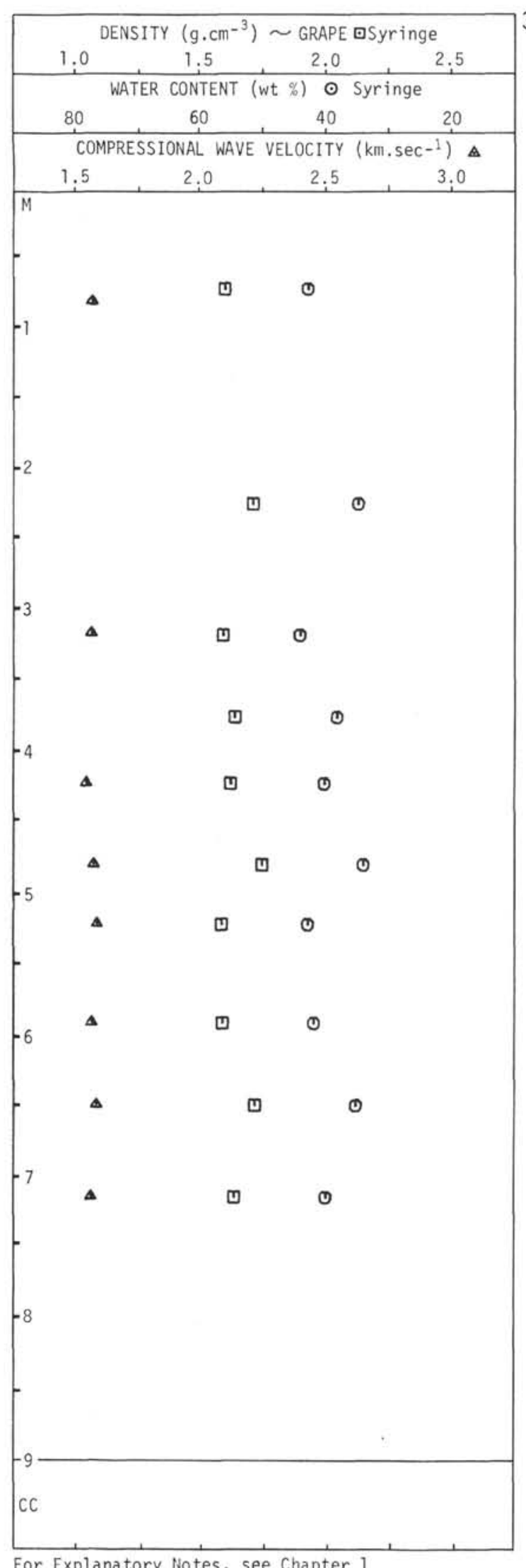

$346-1$

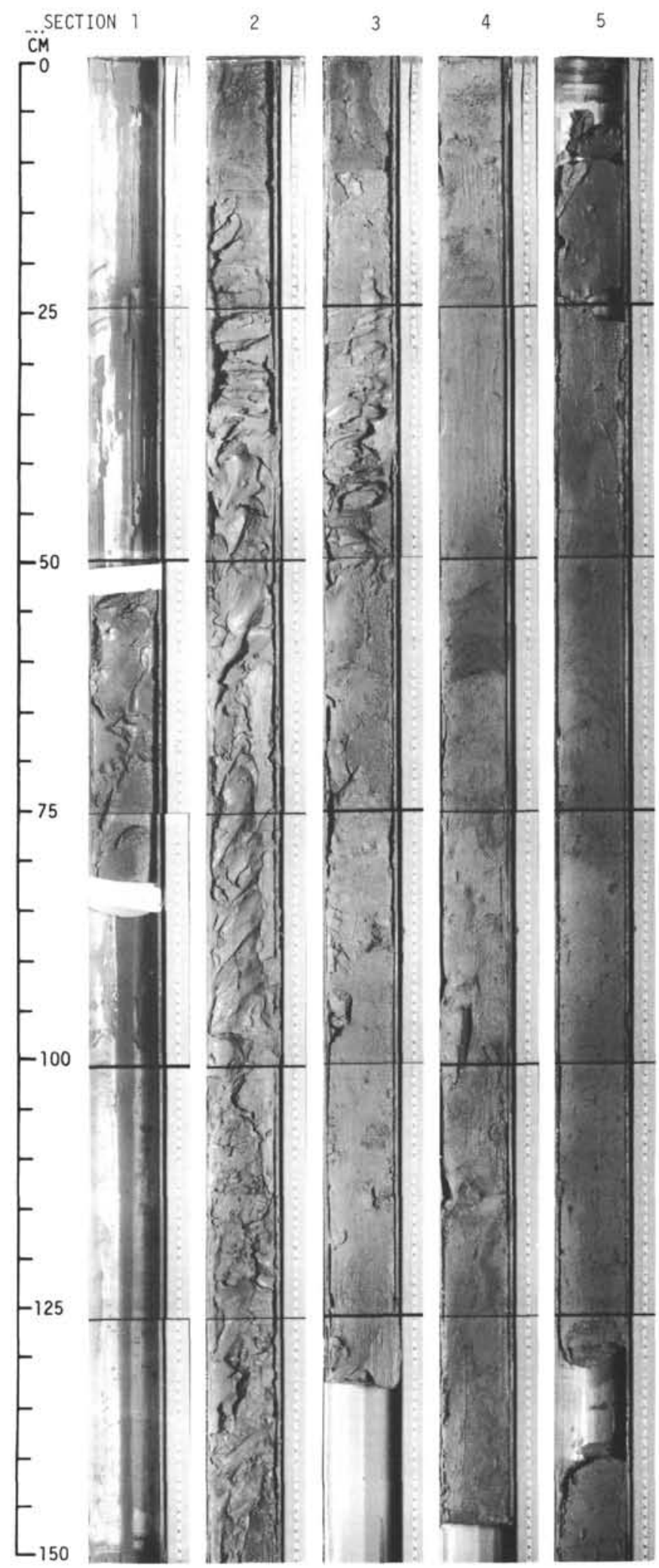




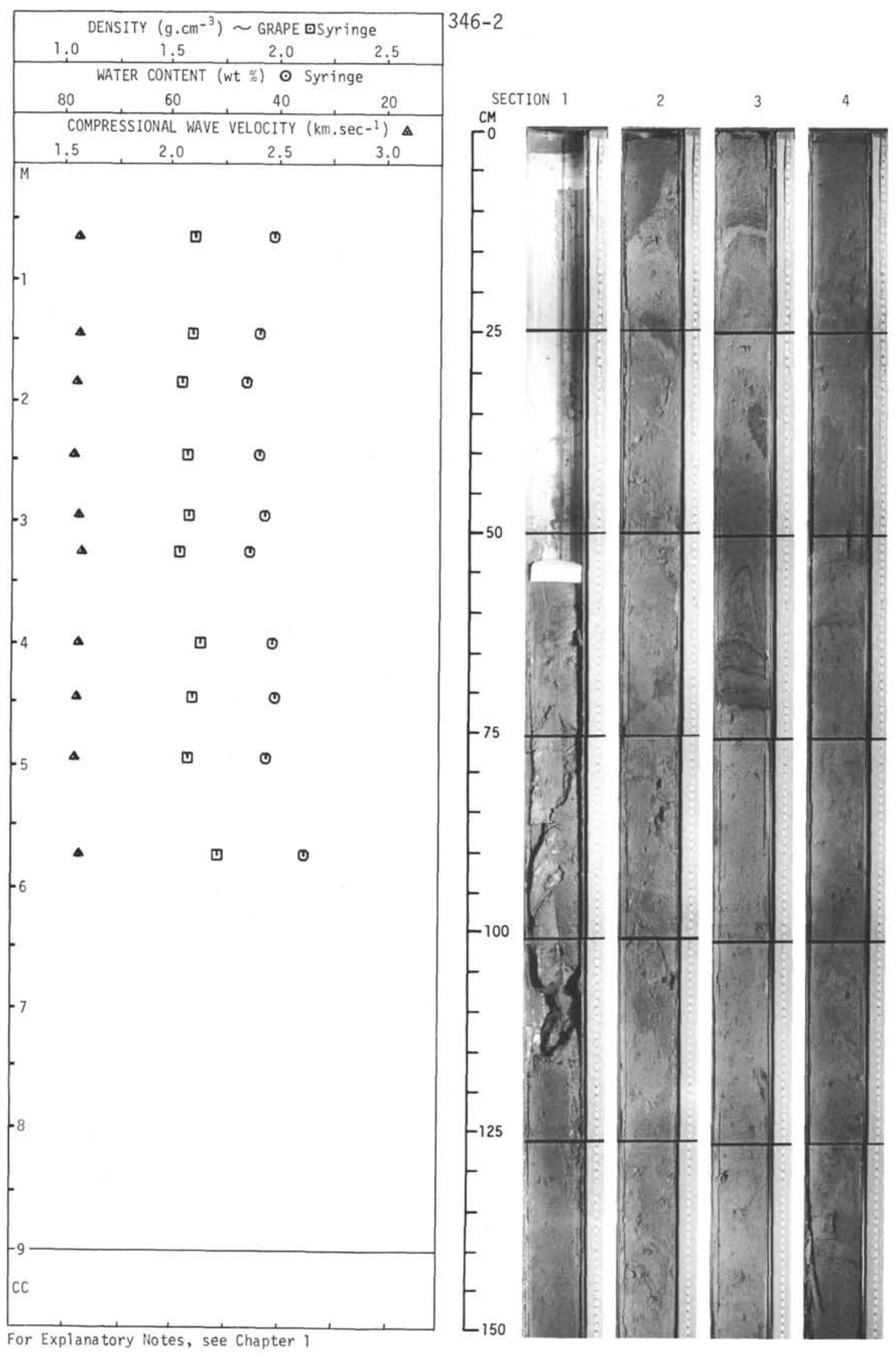




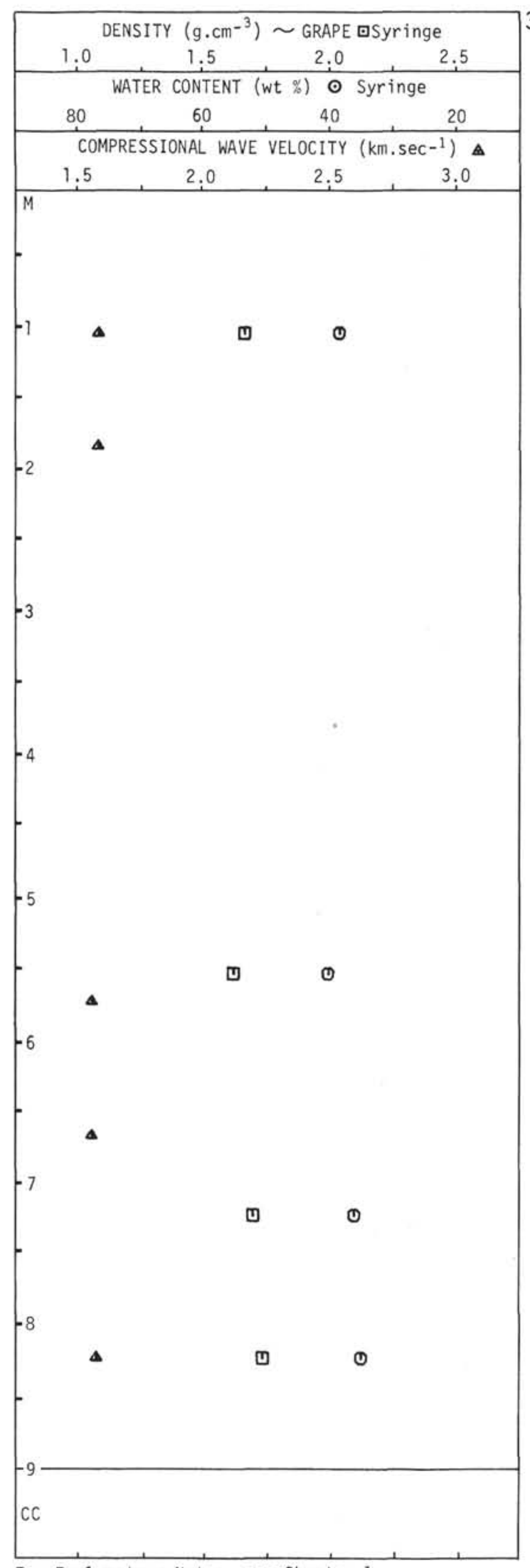

$346-3$

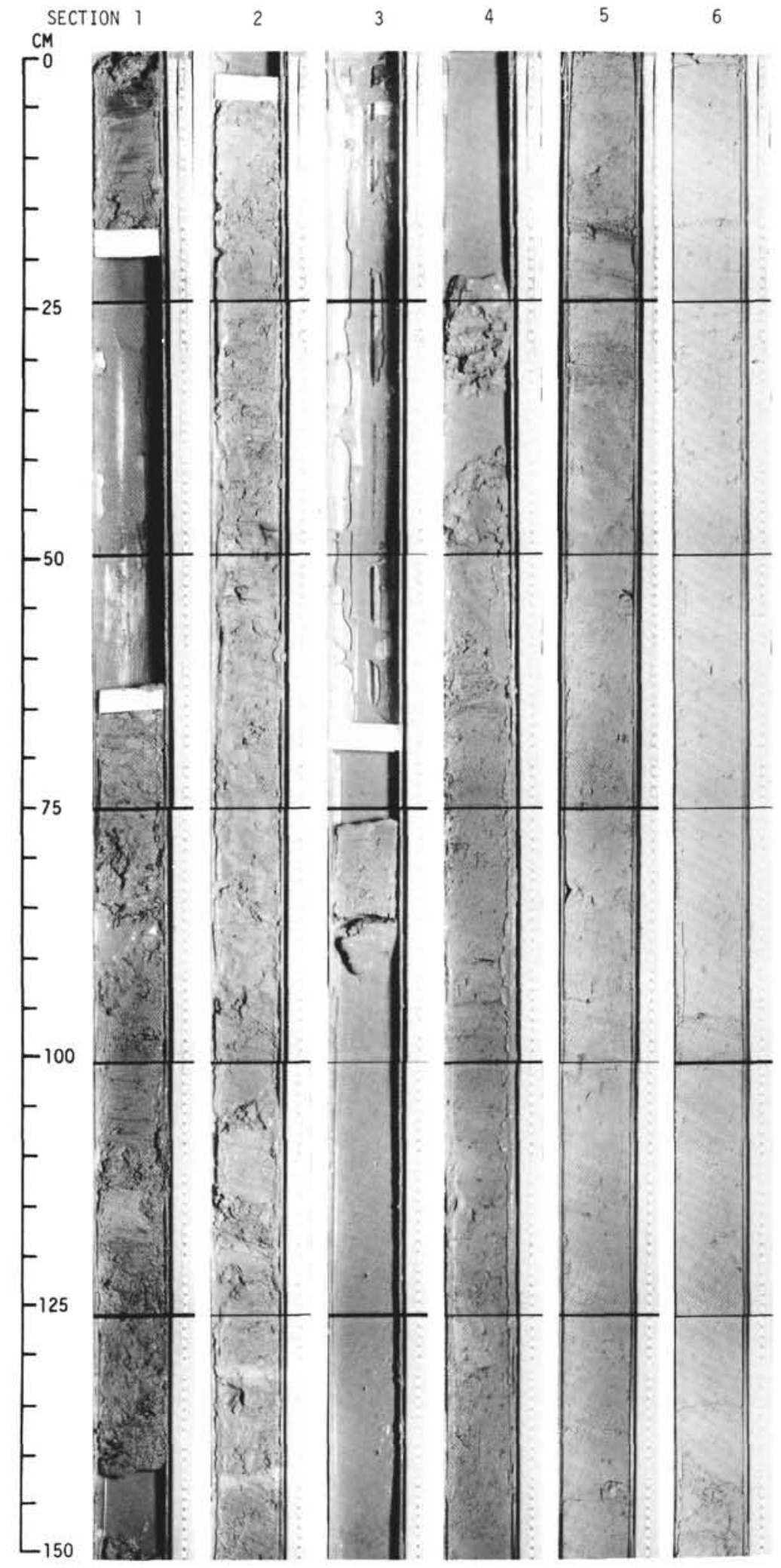




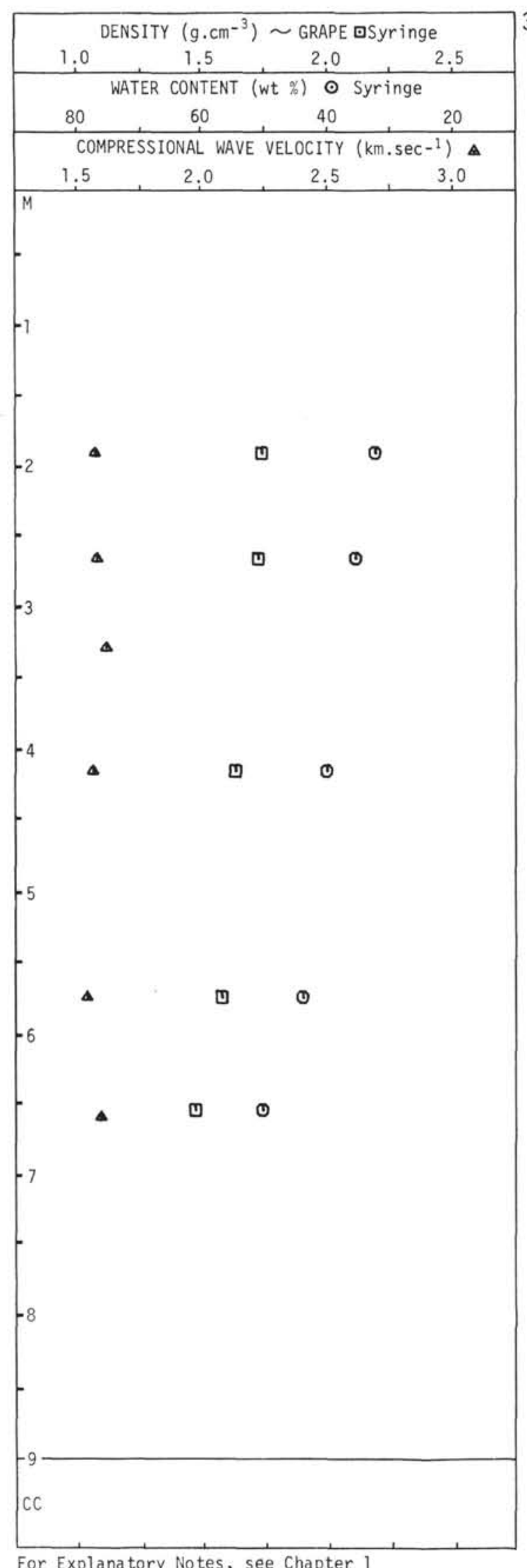

$346-4$

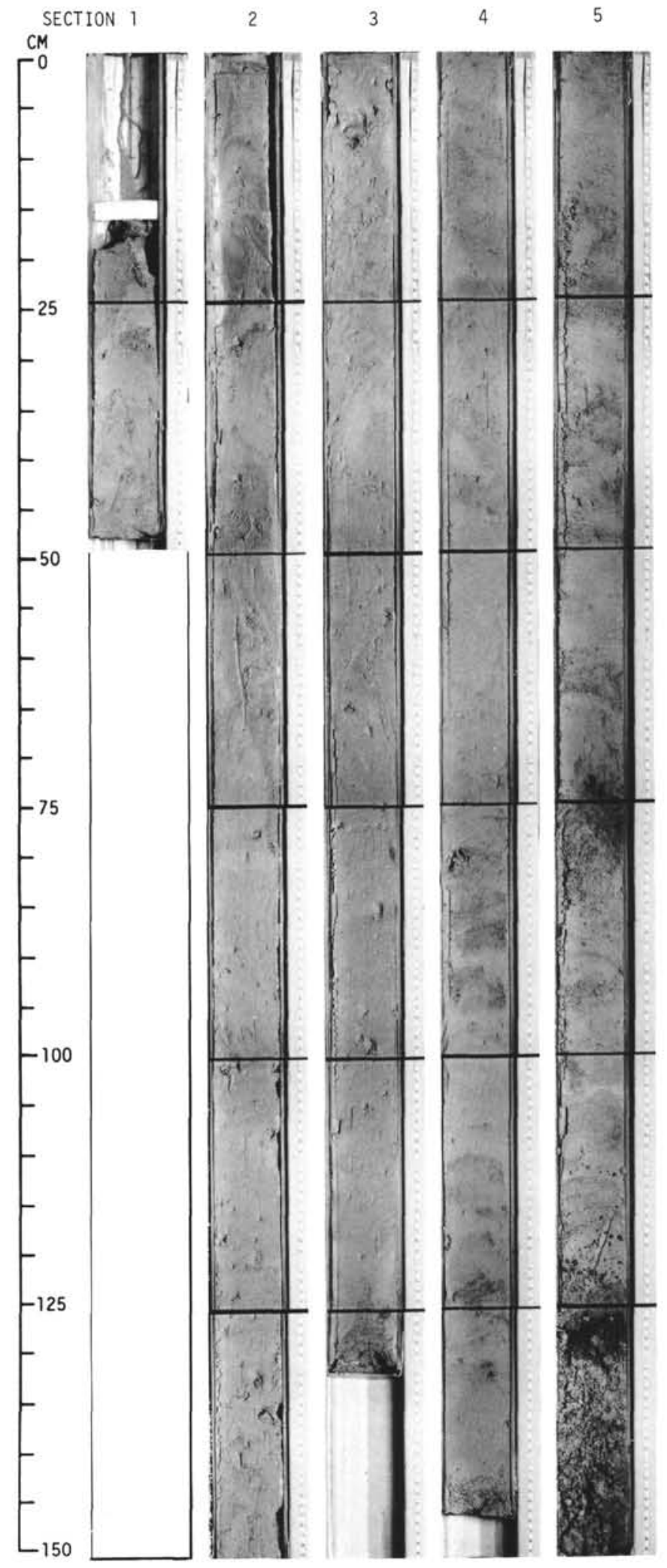




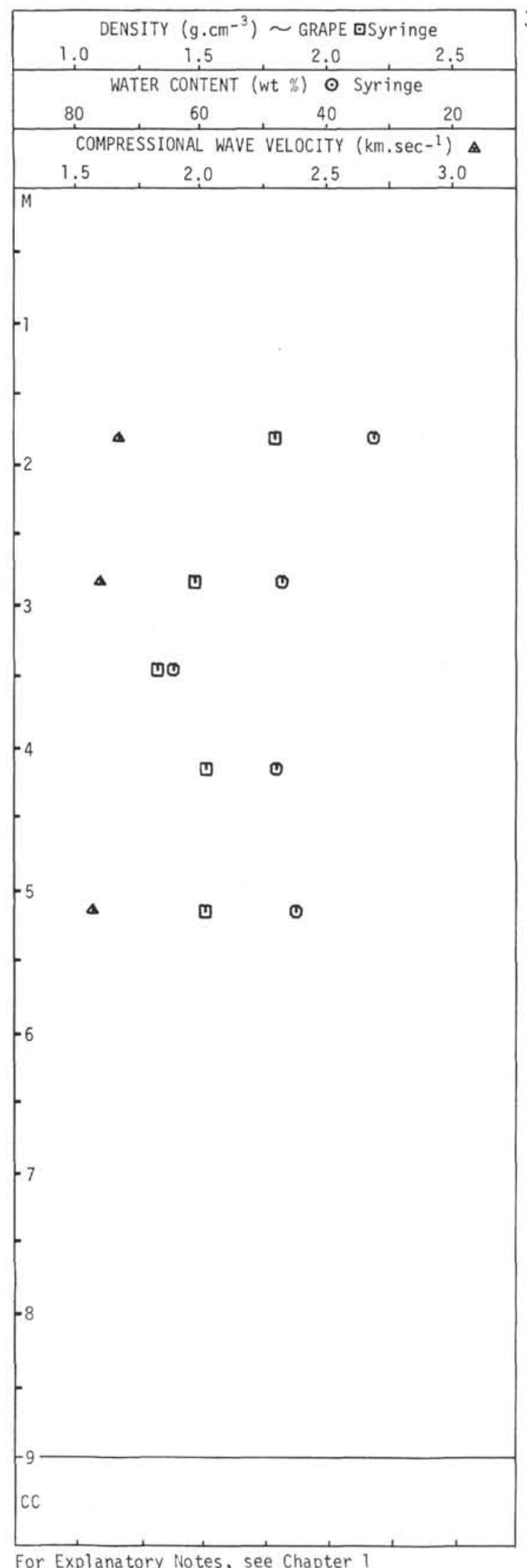

$346-5$

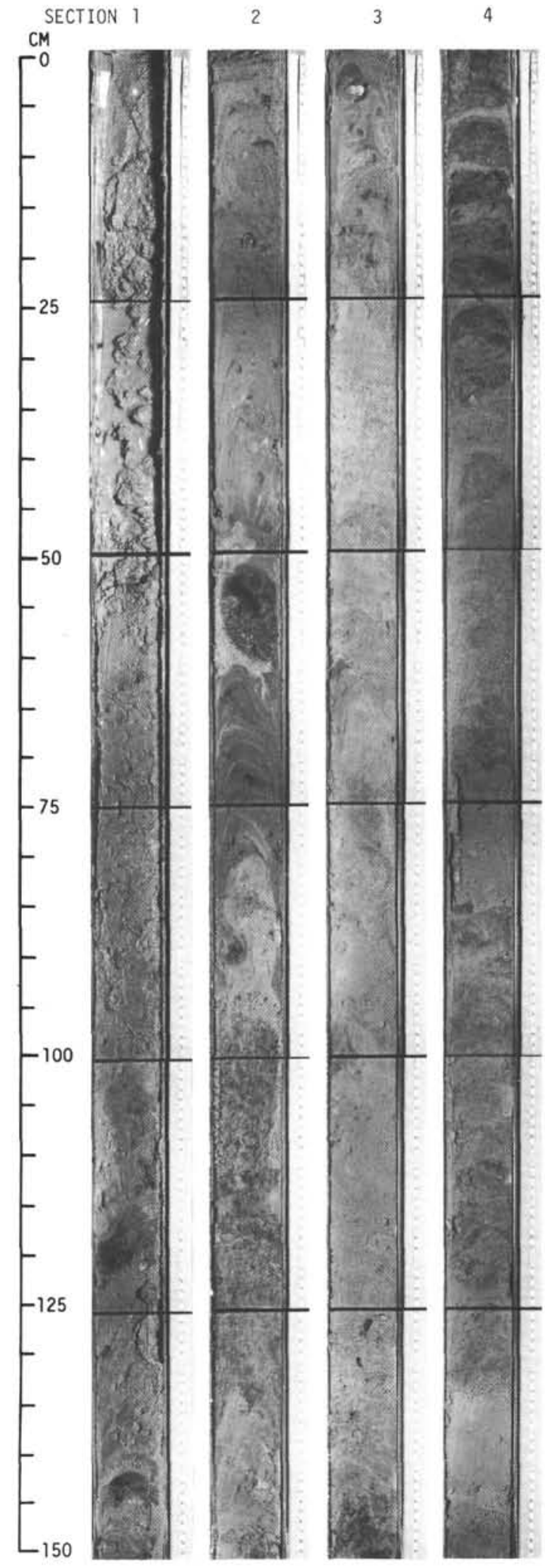




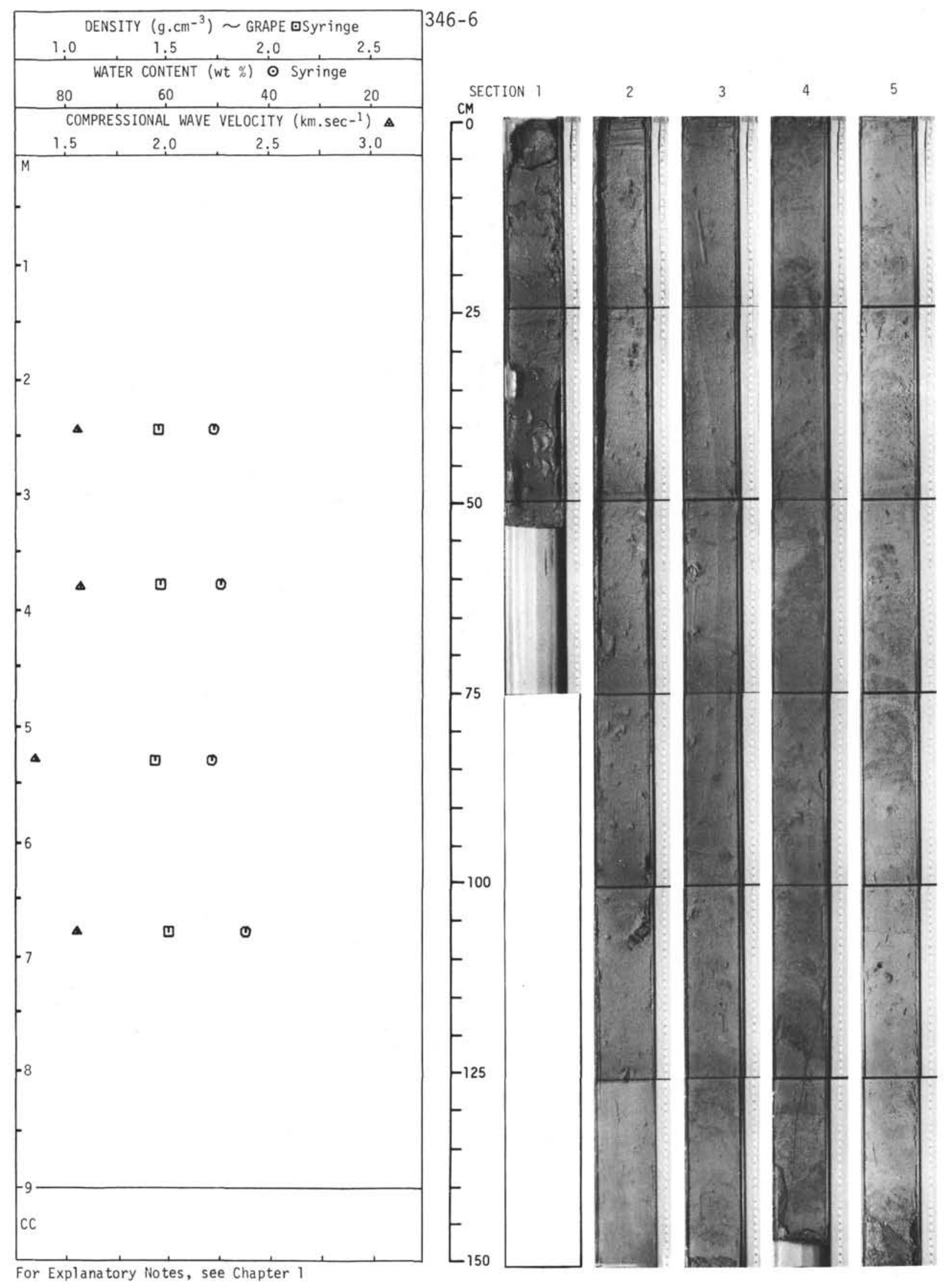




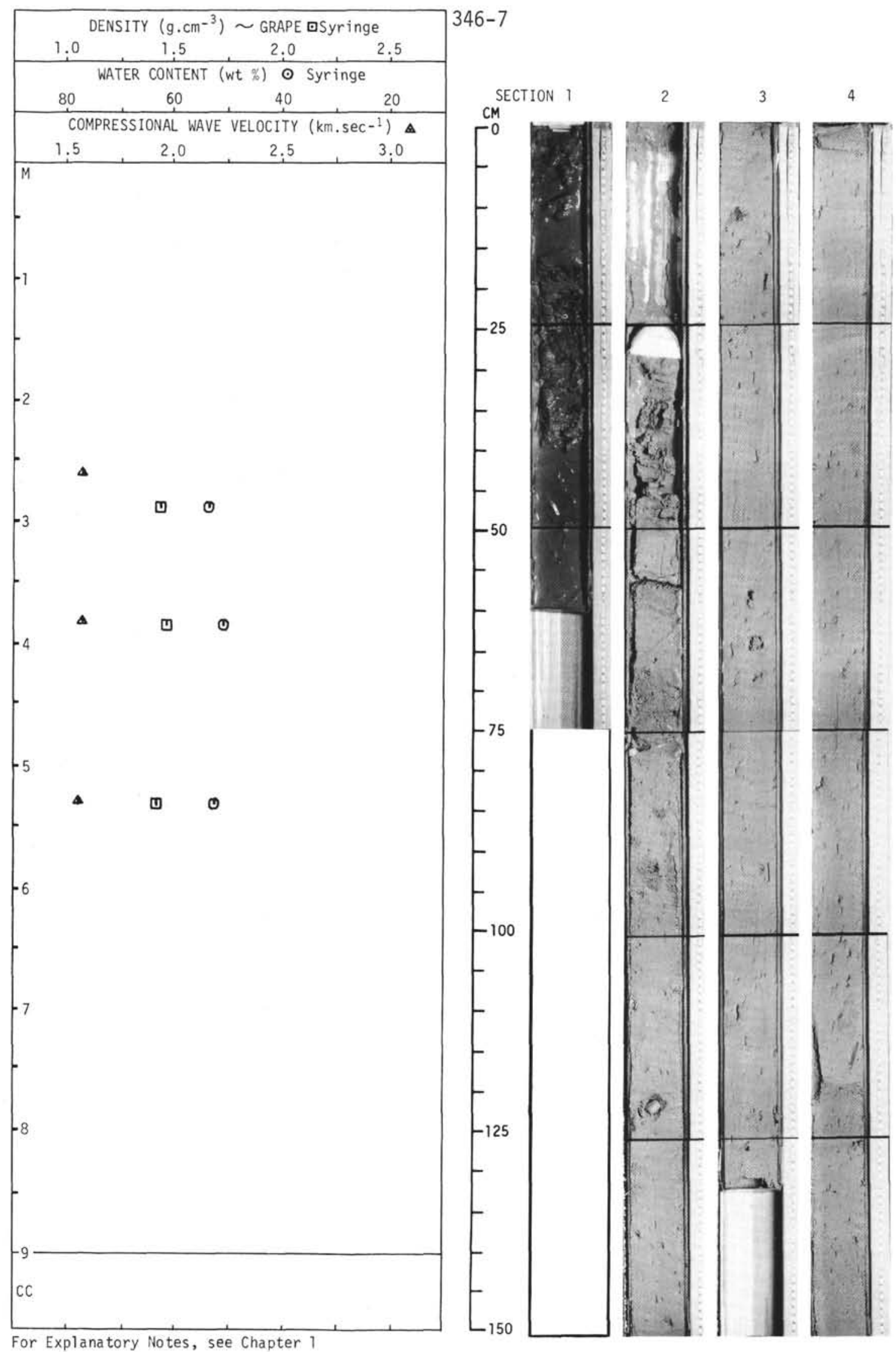




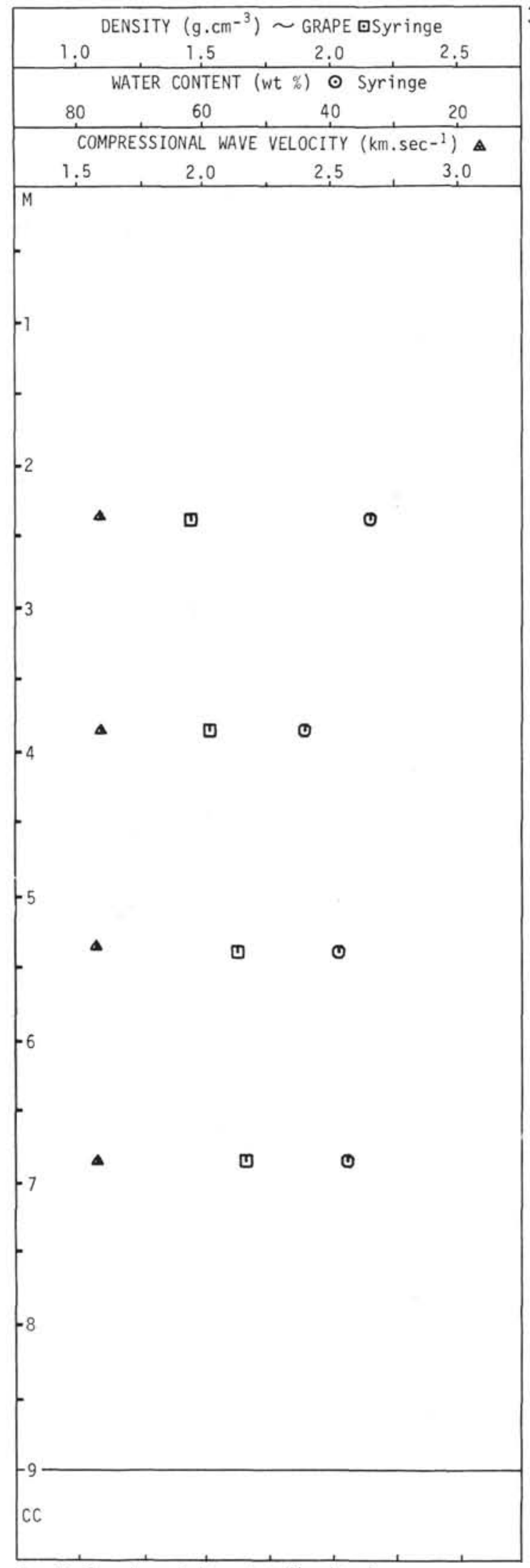

$346-8$

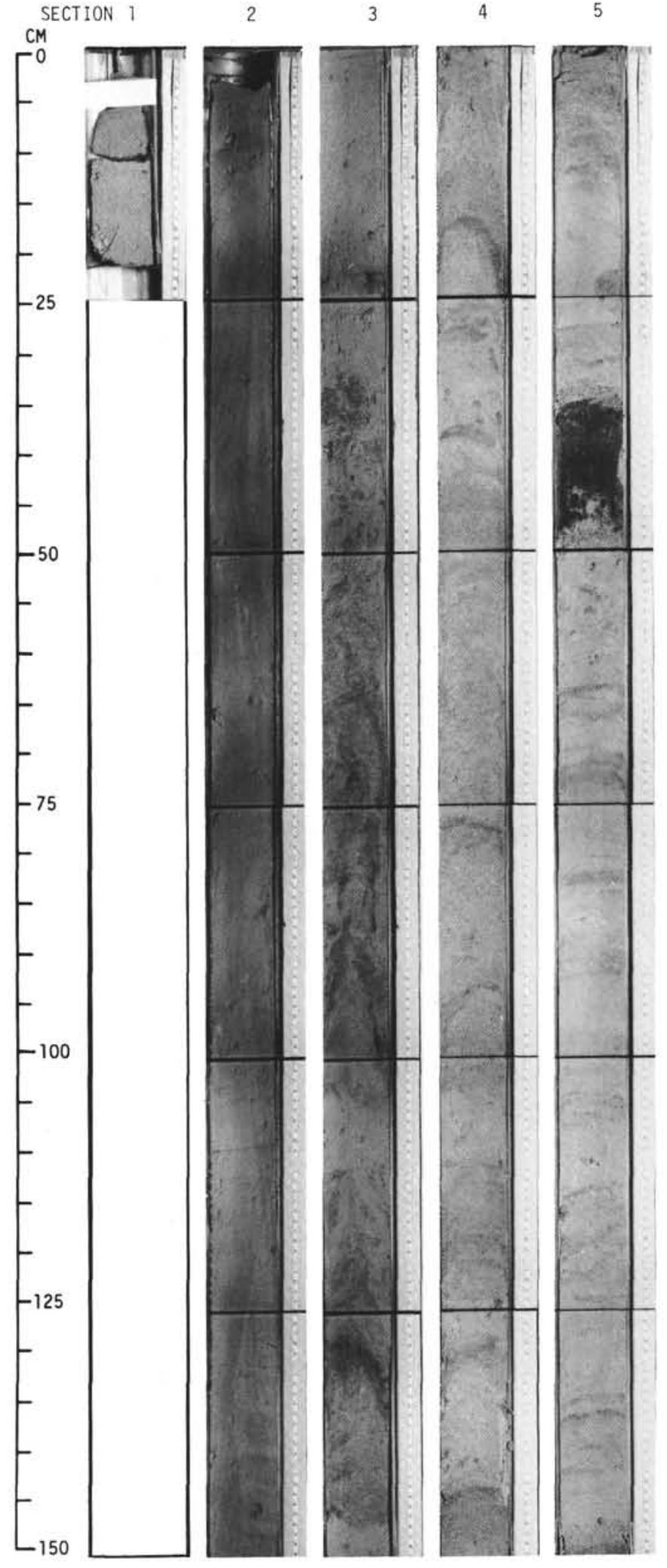




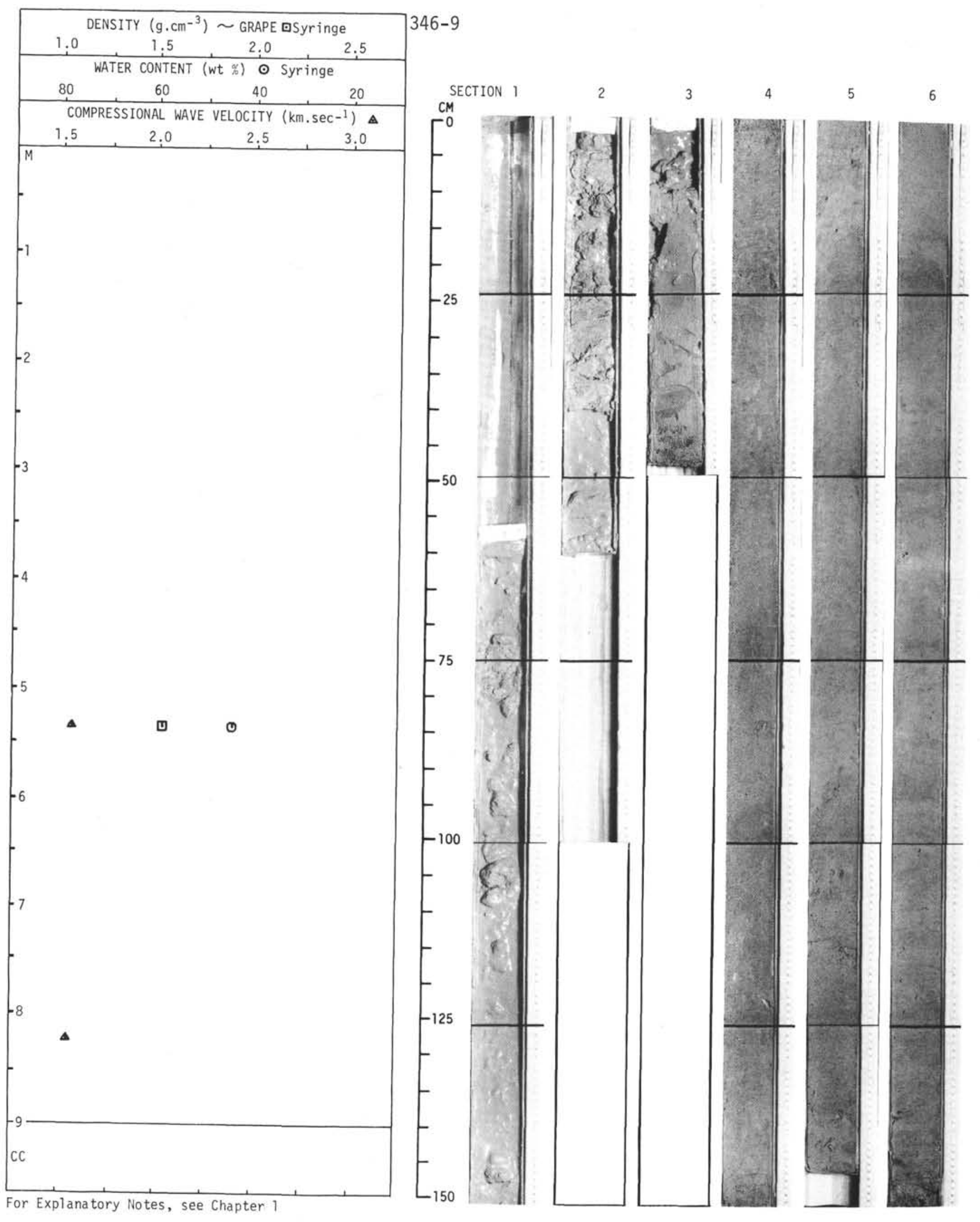




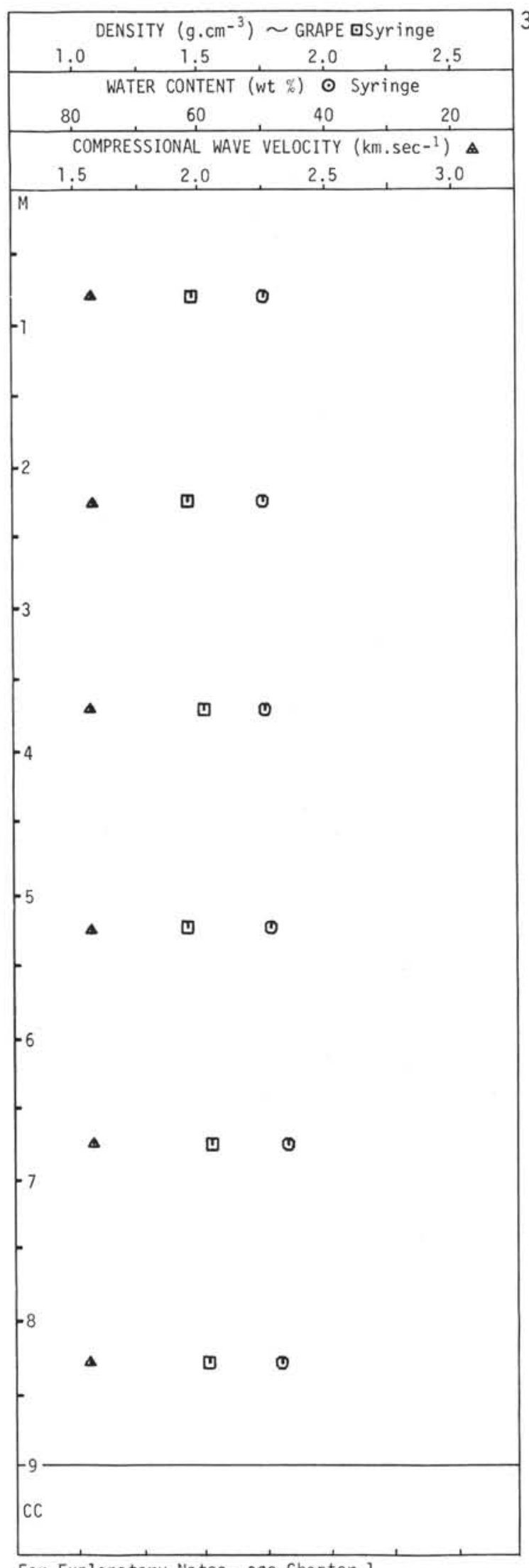

$346-10$

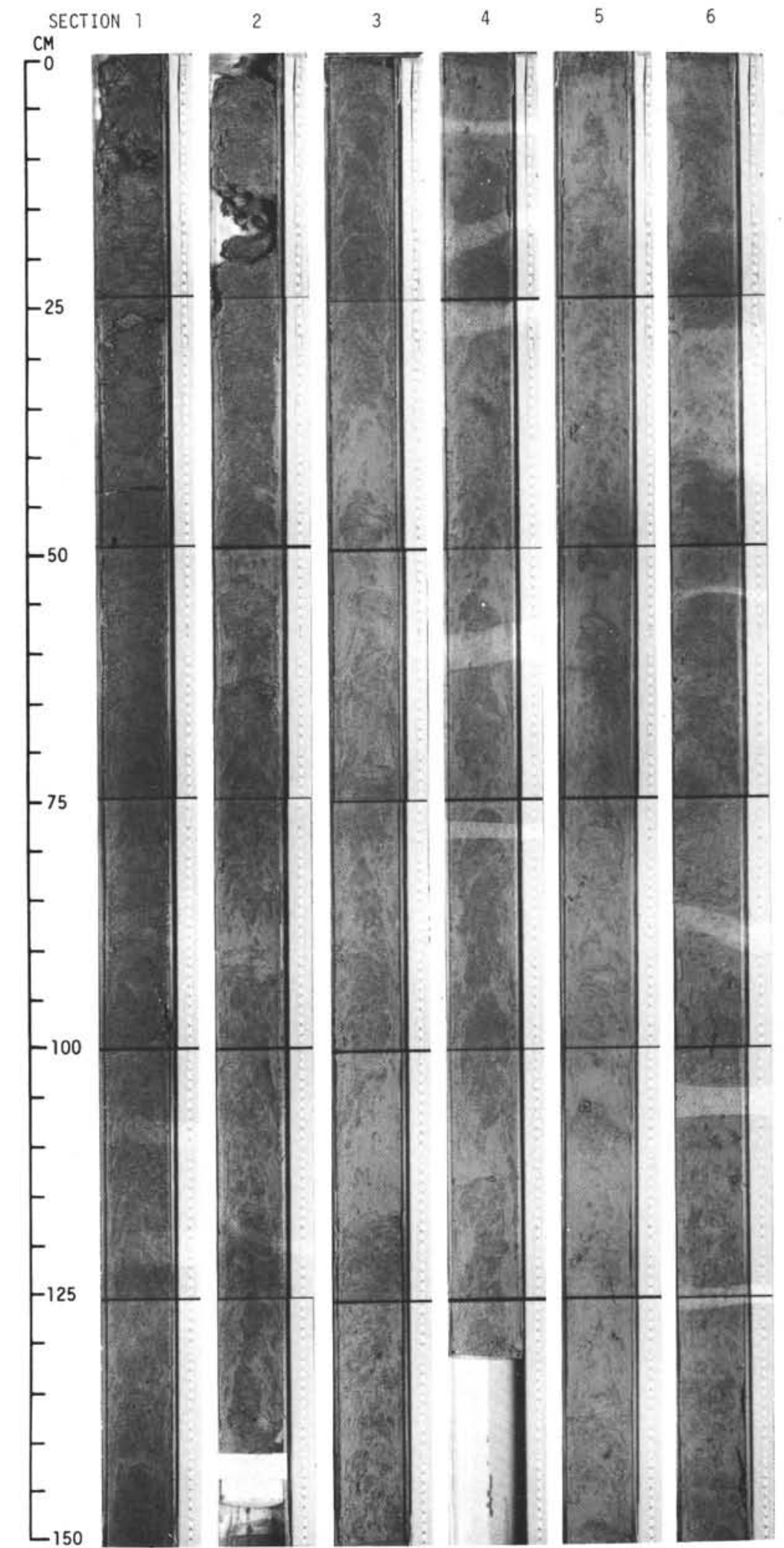




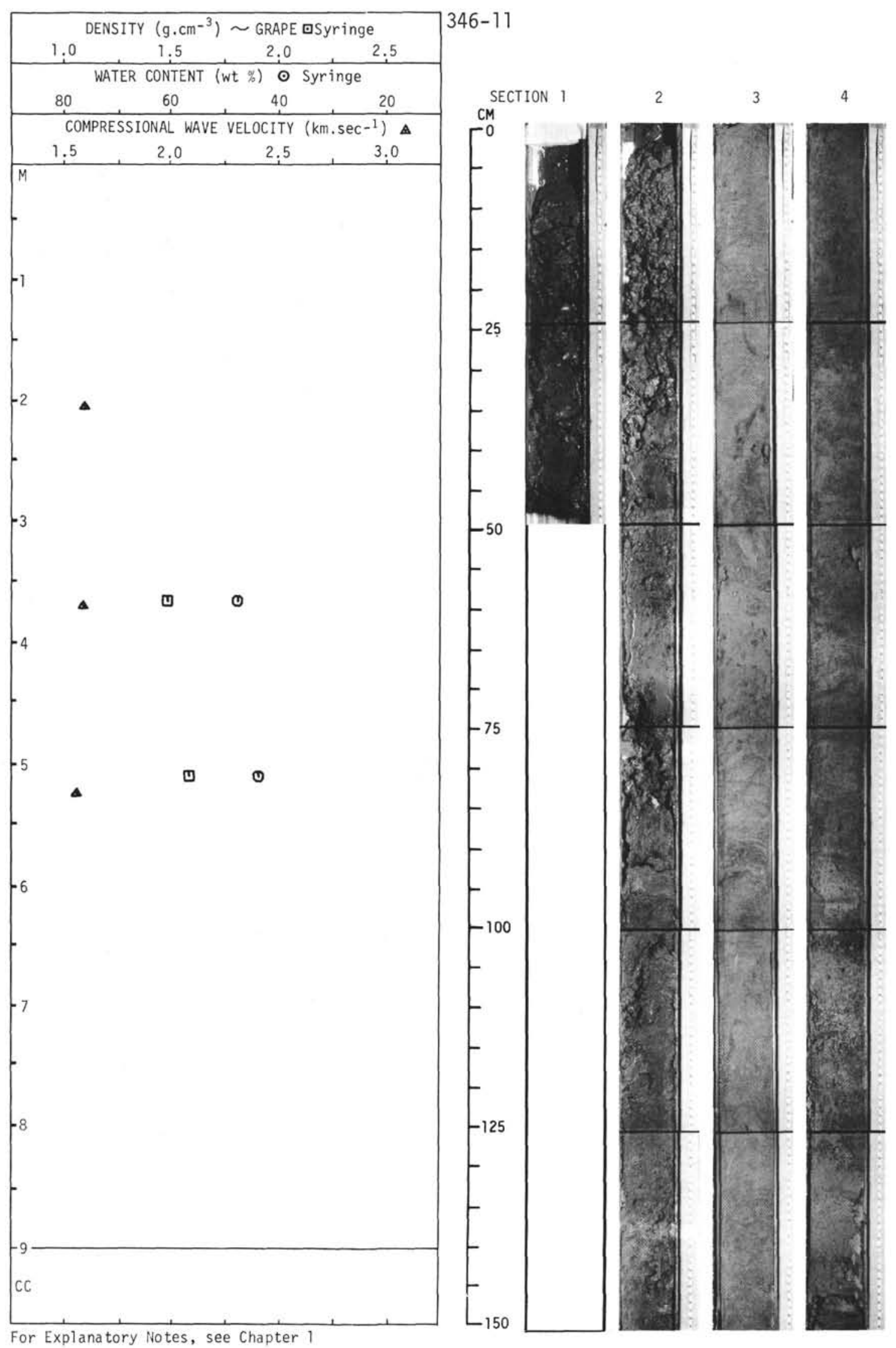




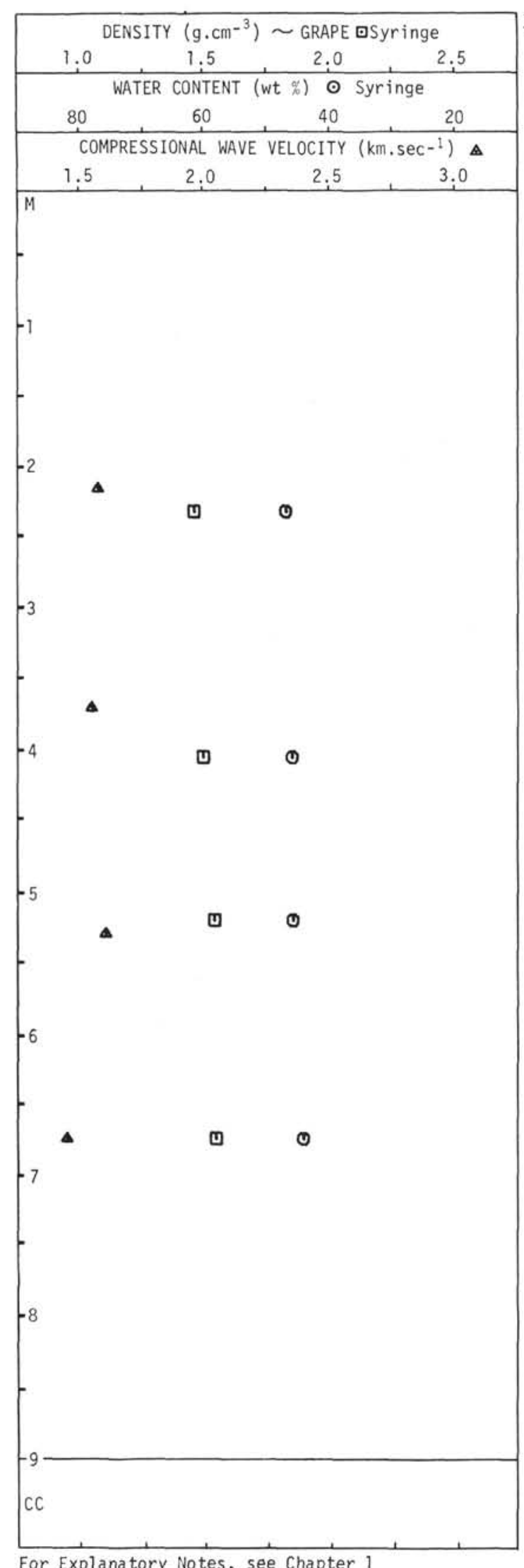

$346-12$

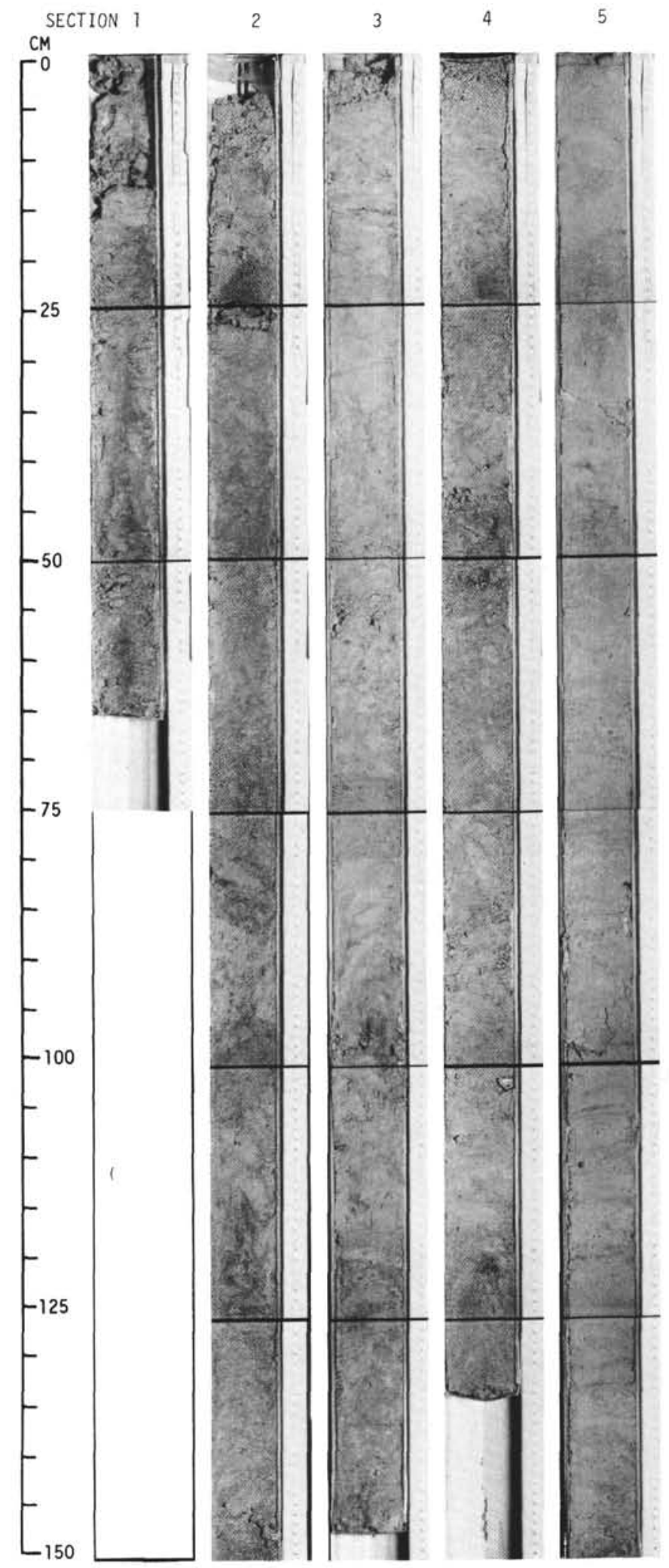




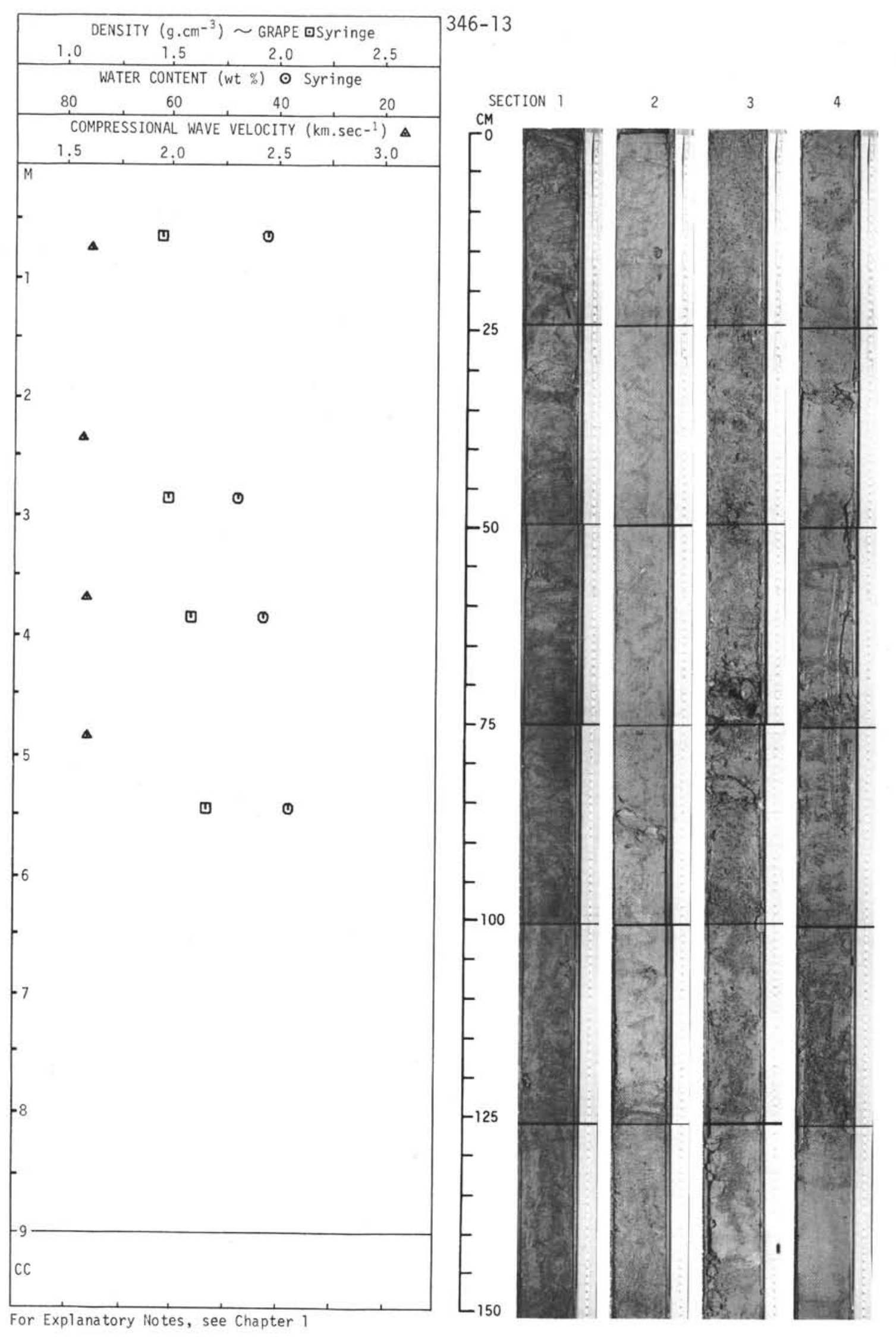




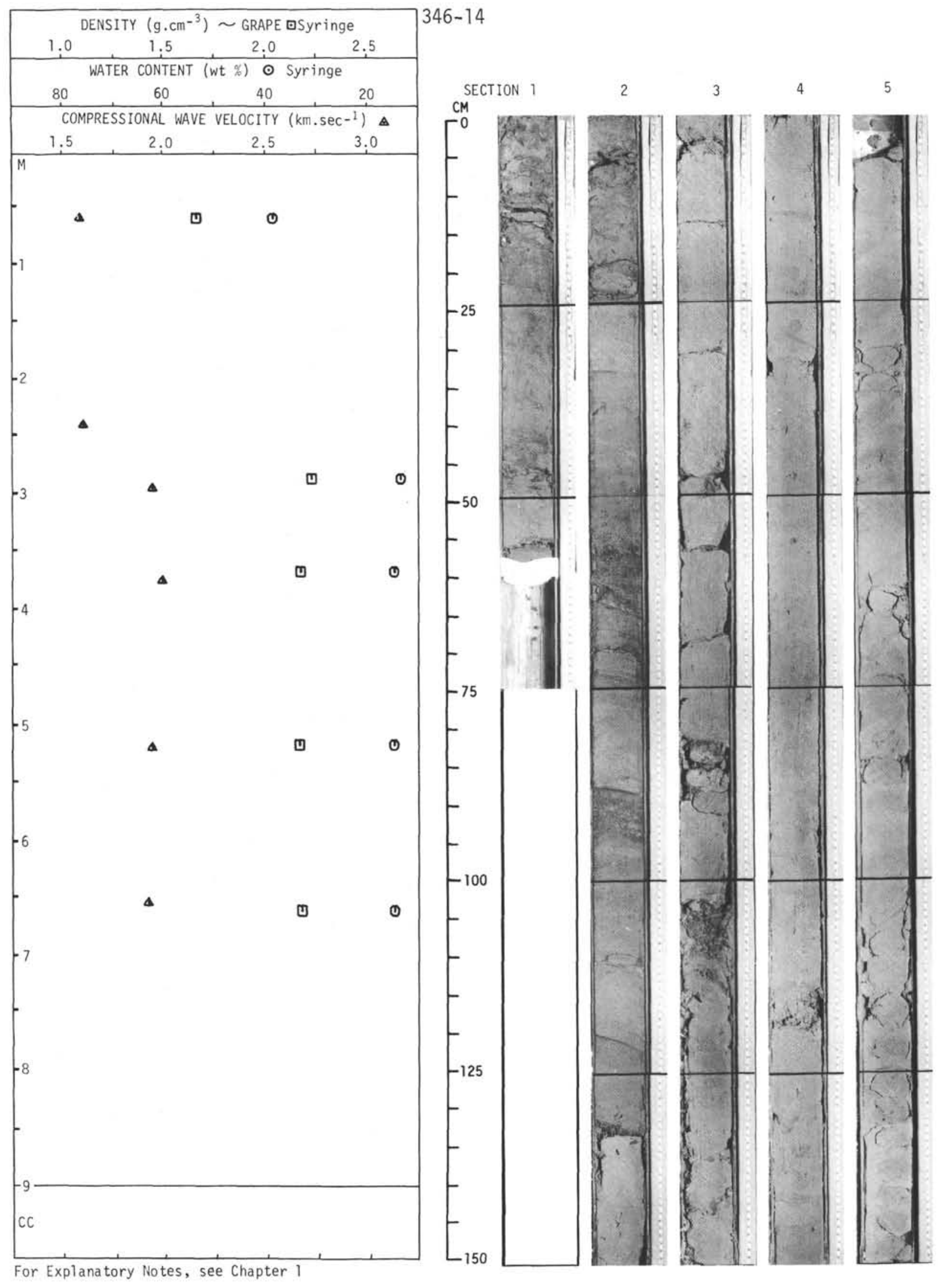




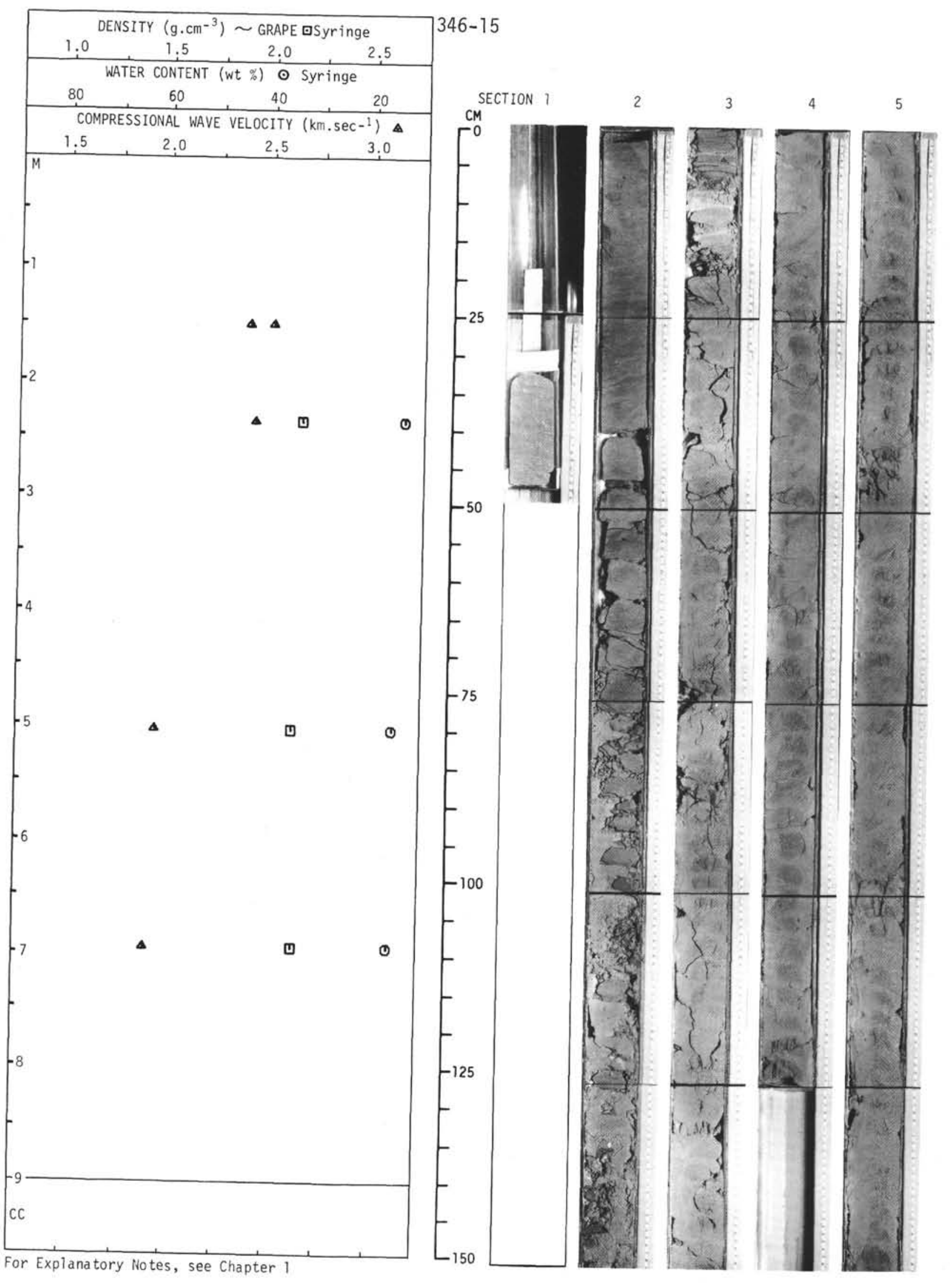




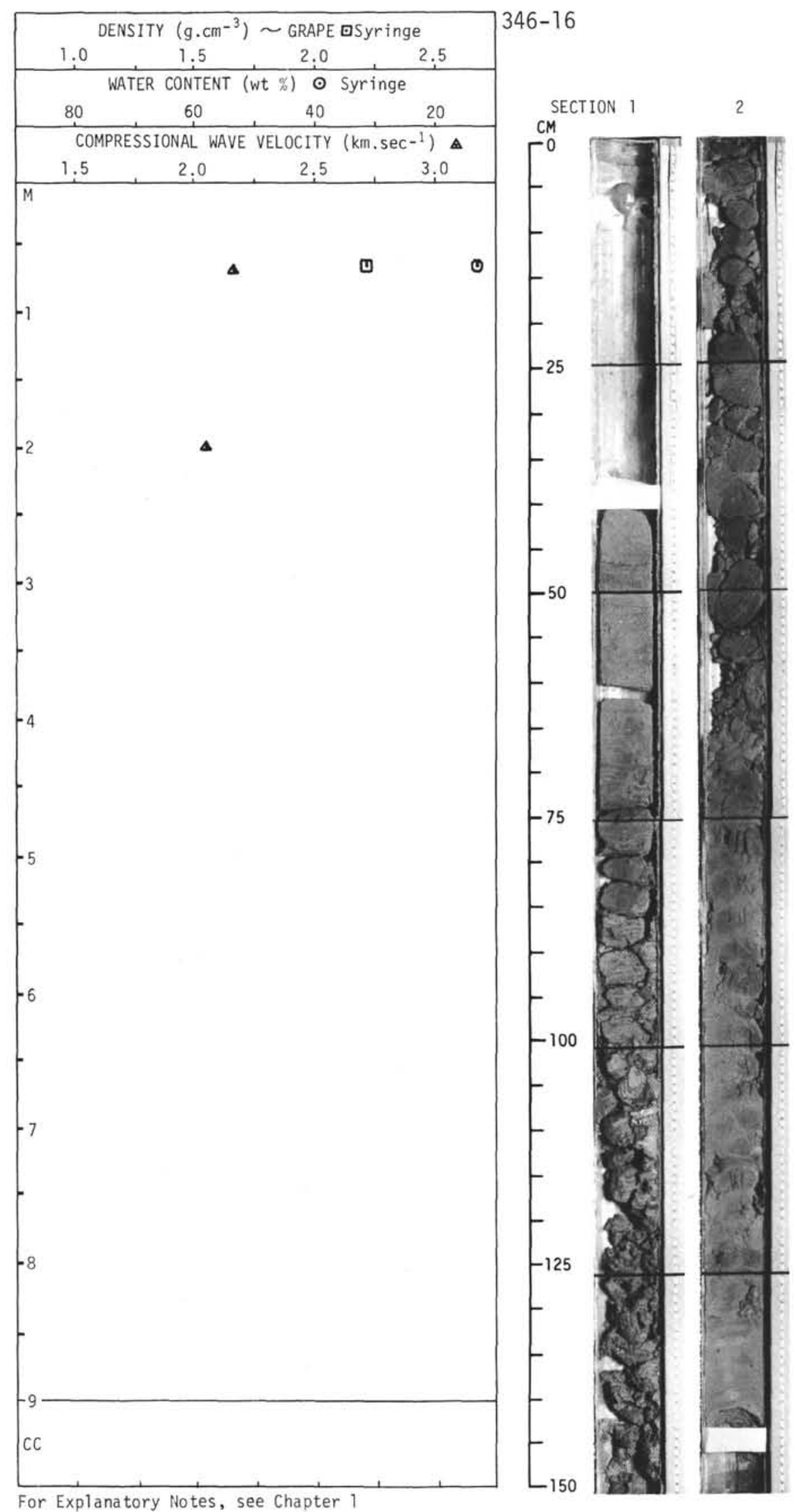




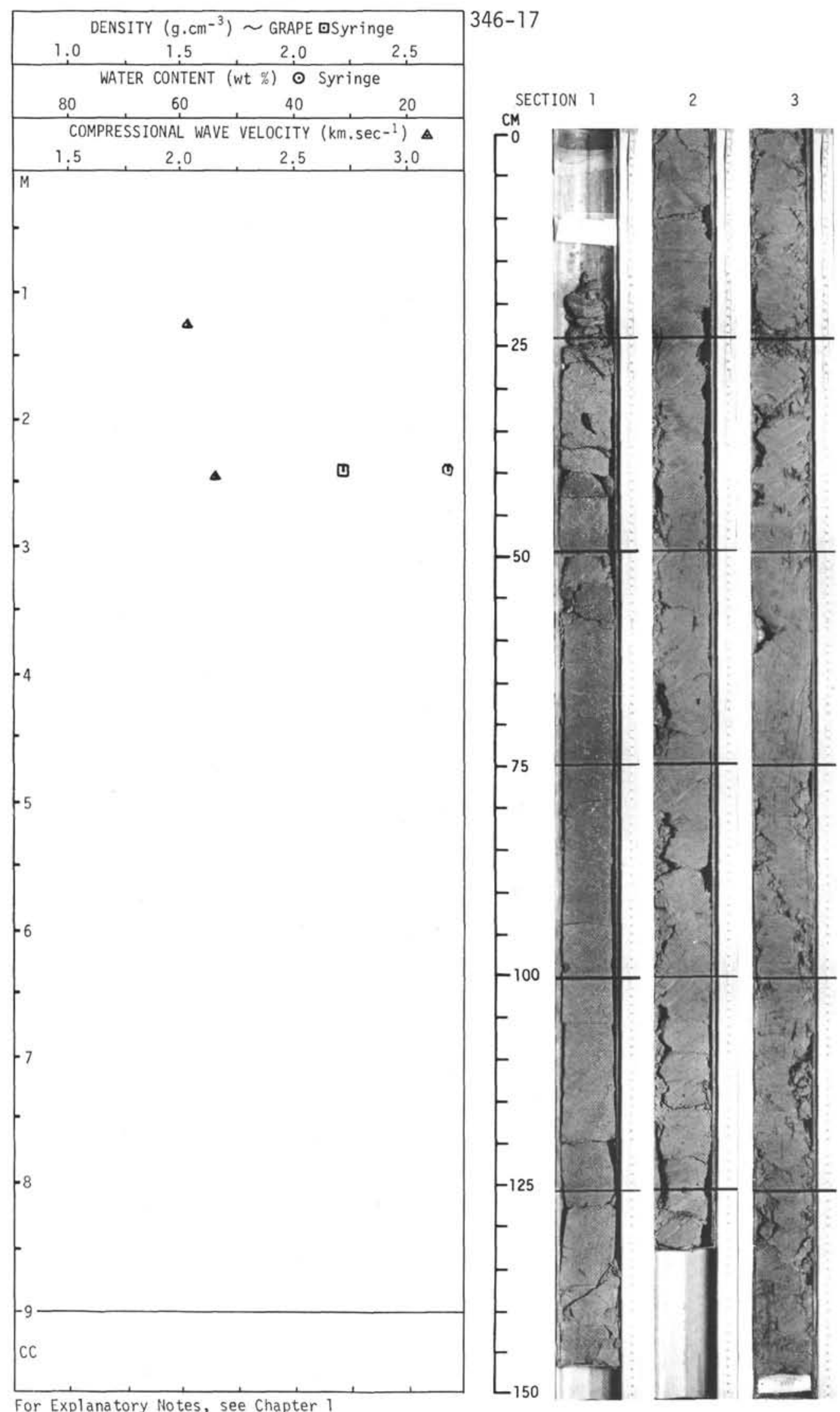




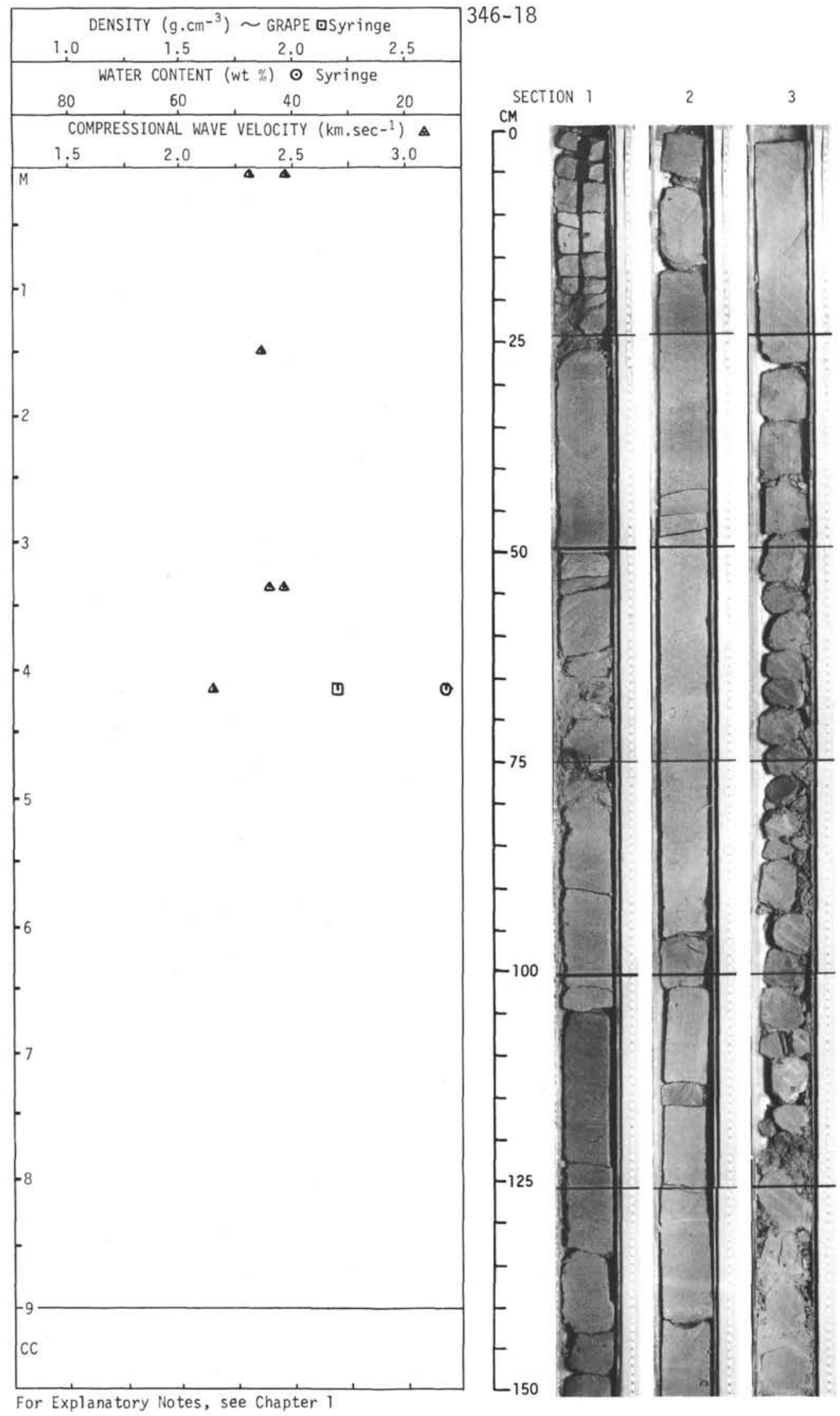




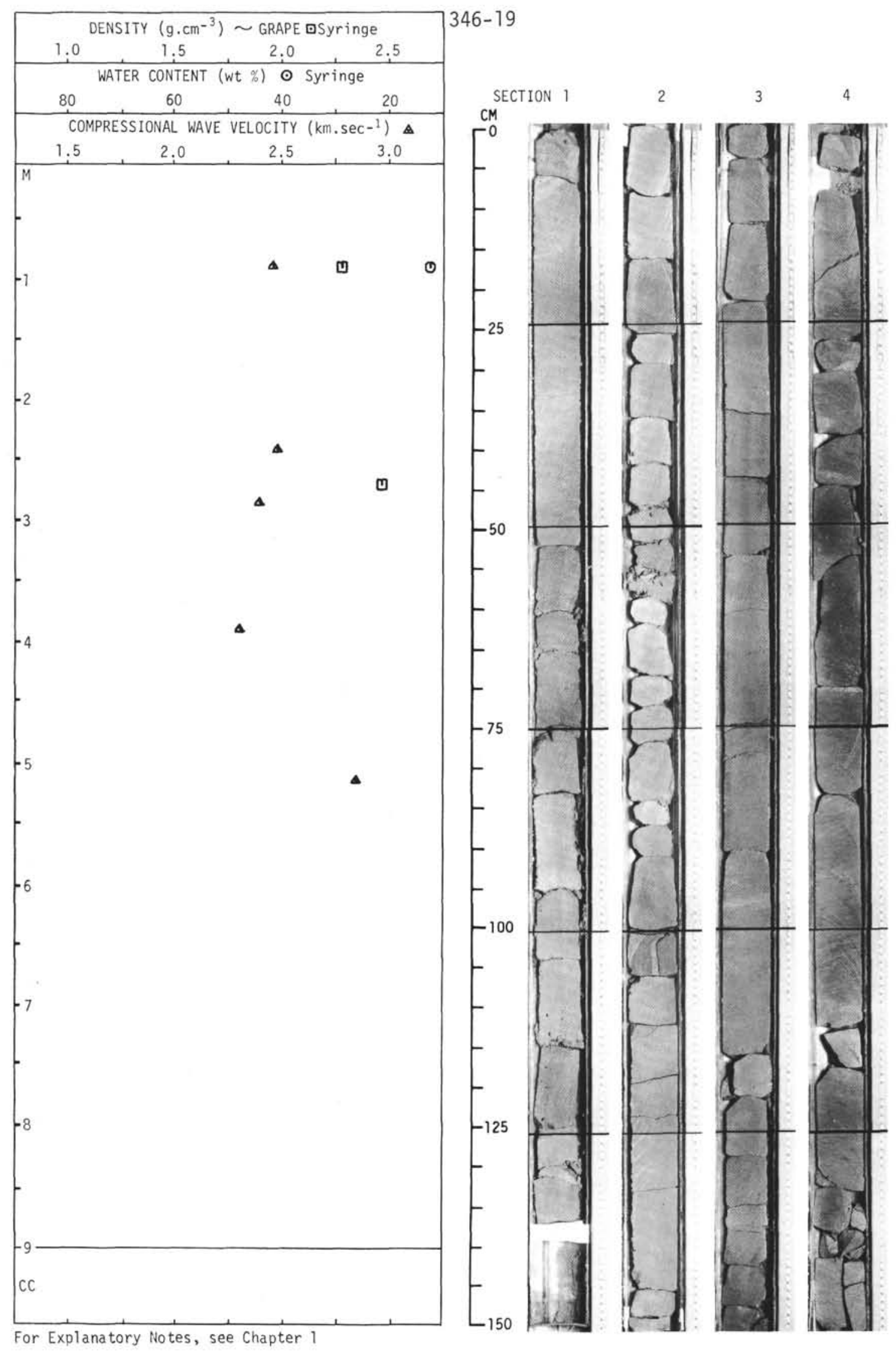




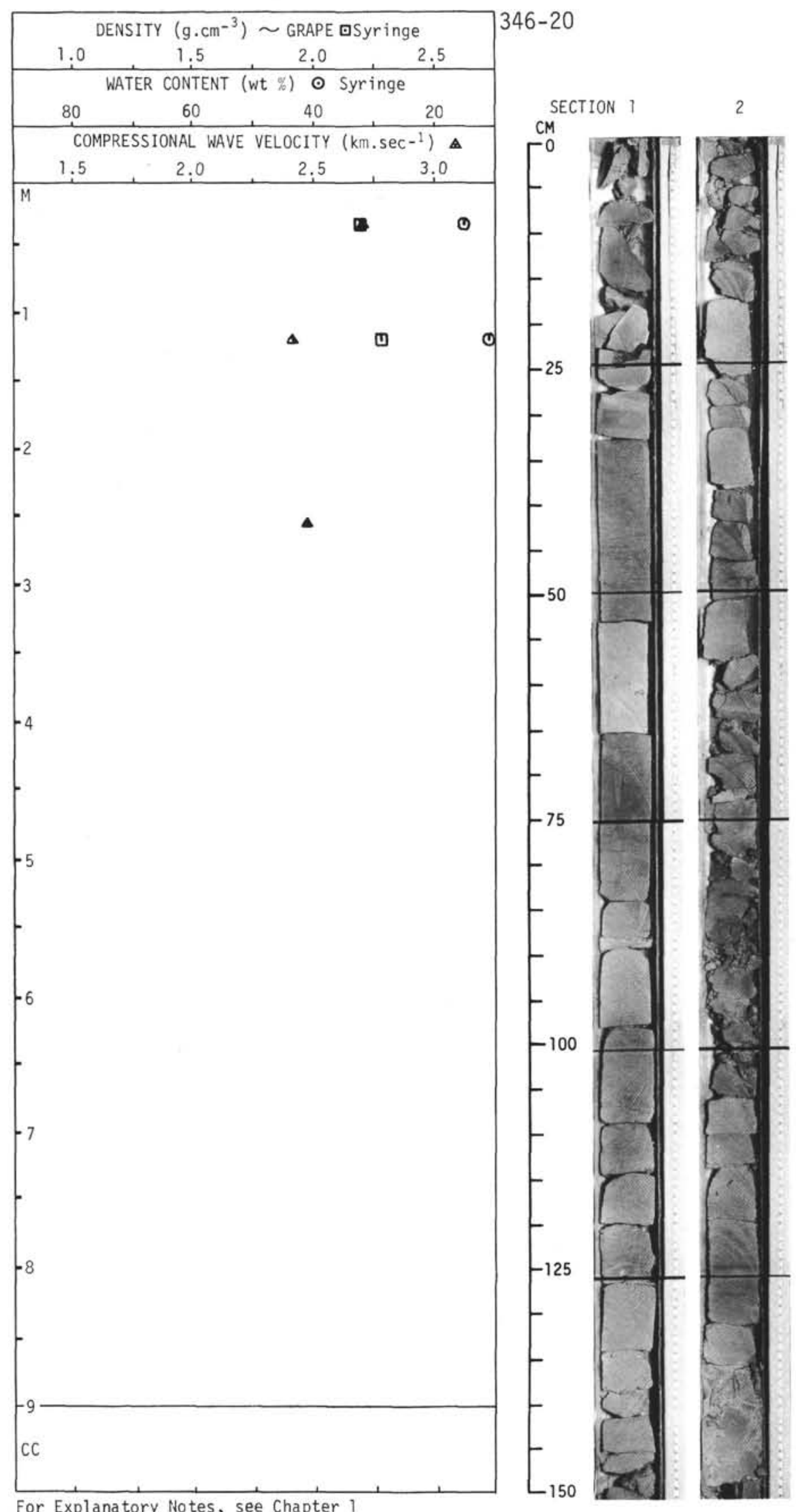



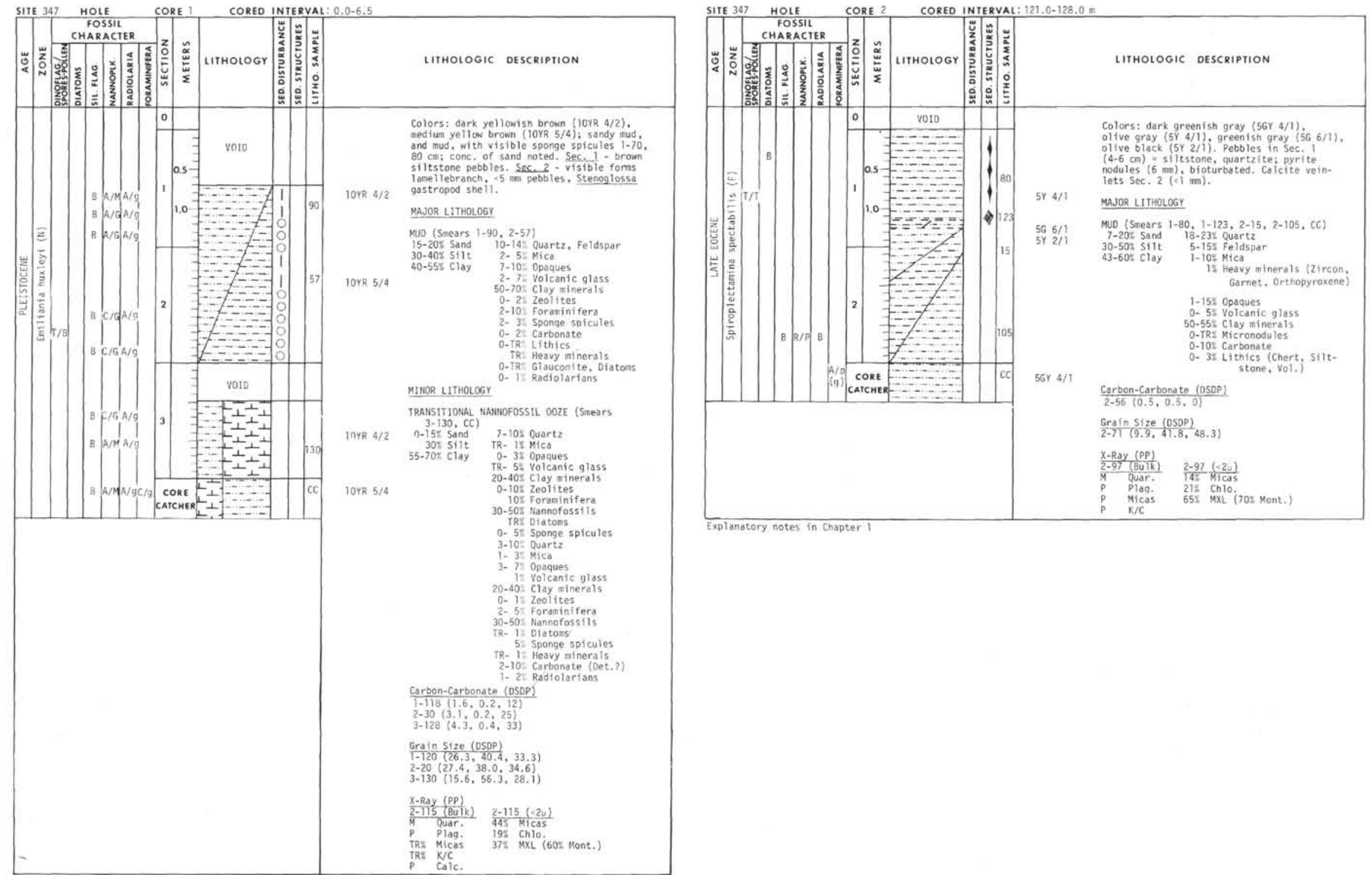

planotory notes in Chapter I 


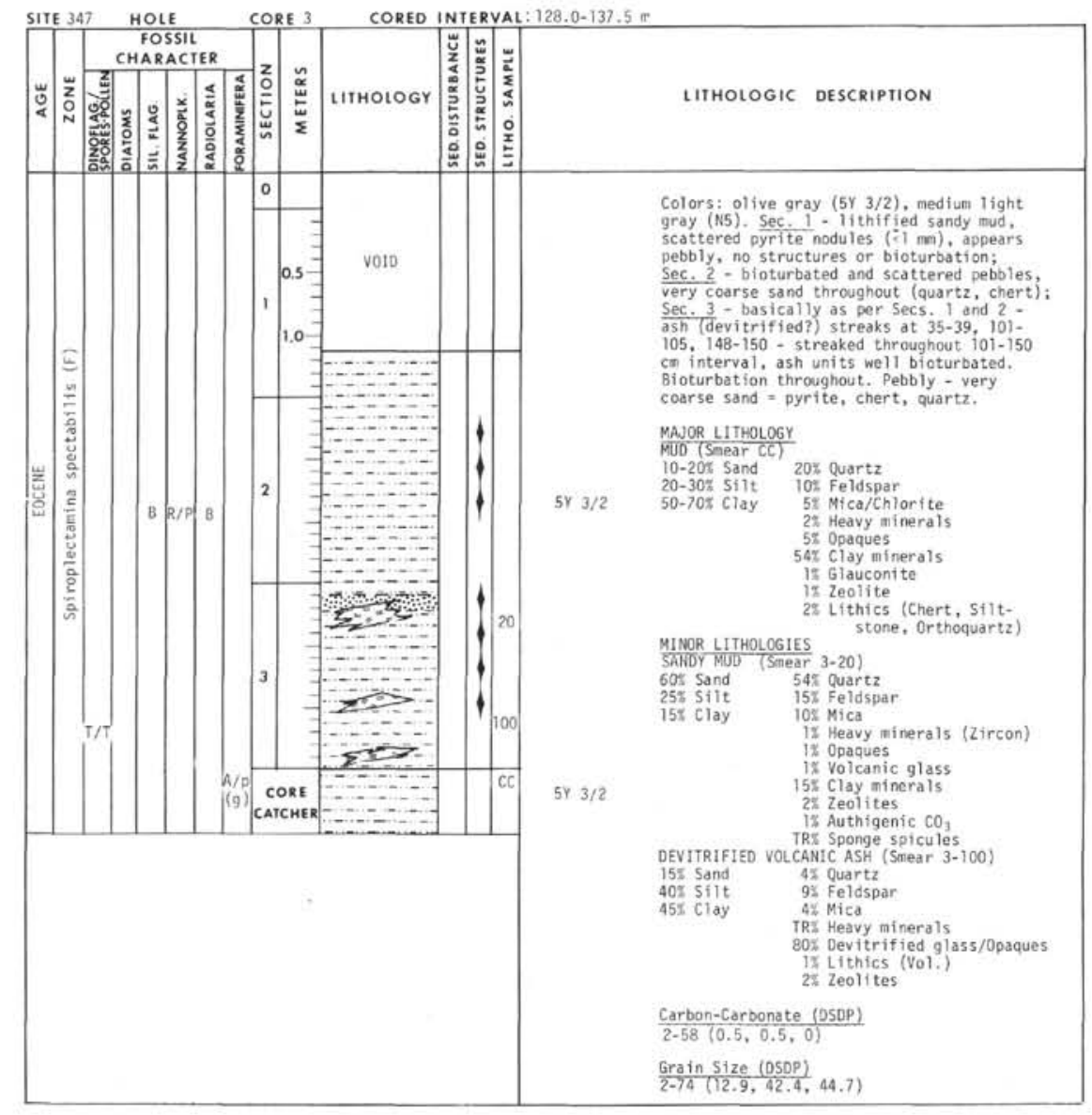

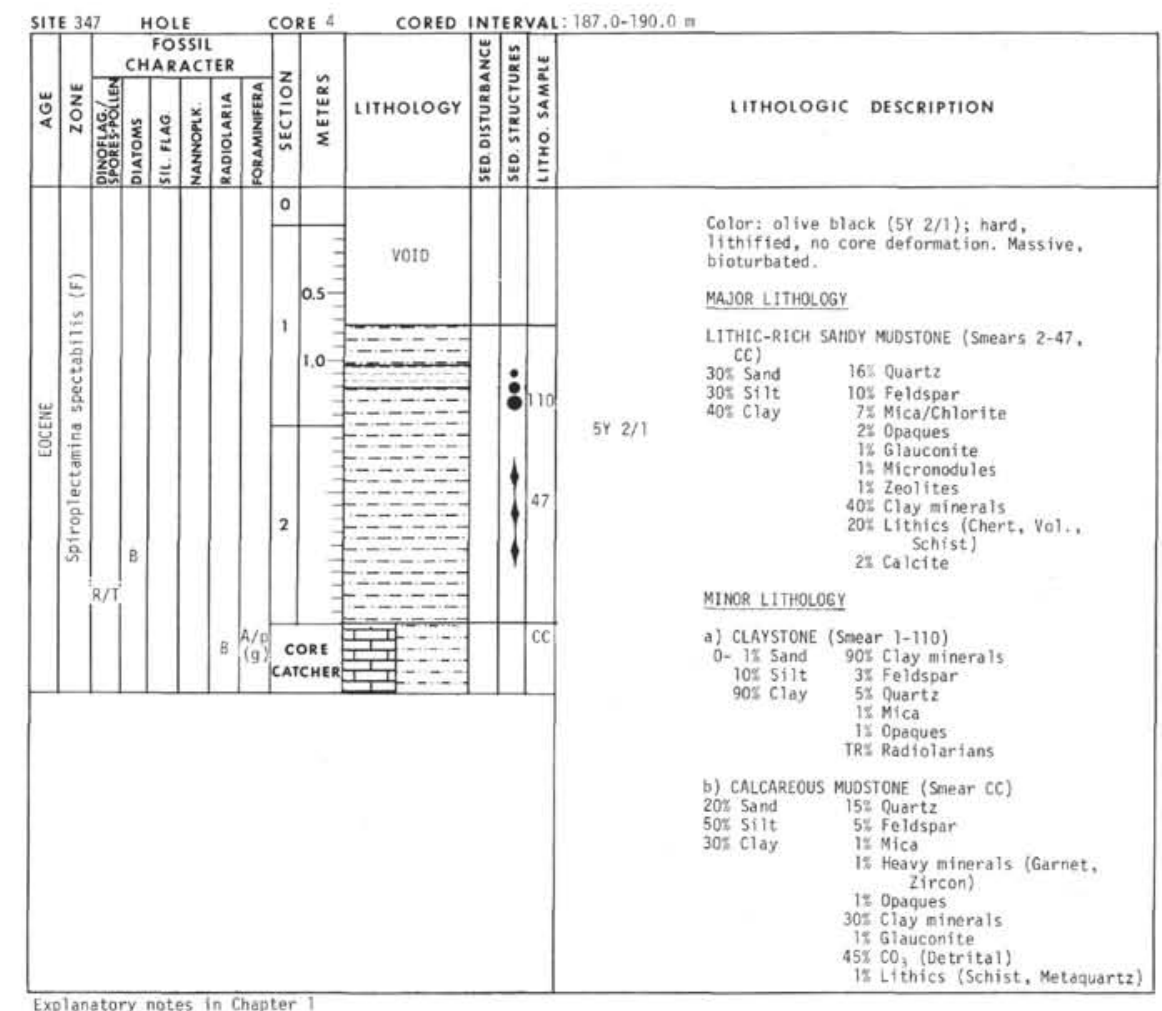




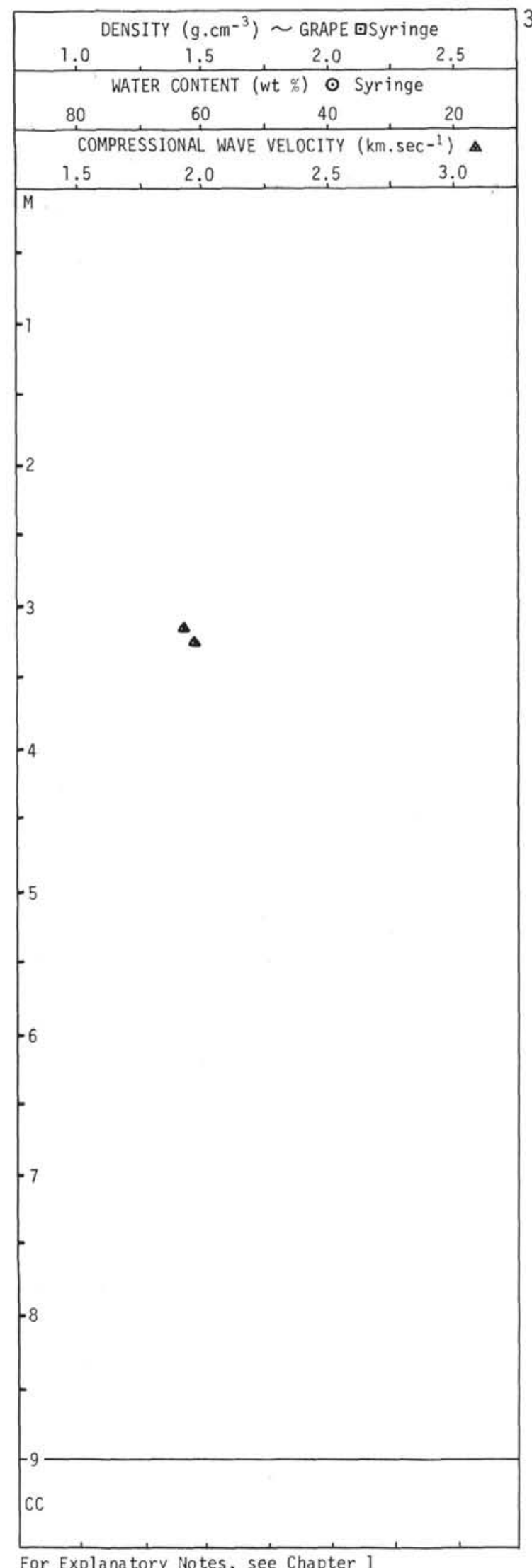

347-1

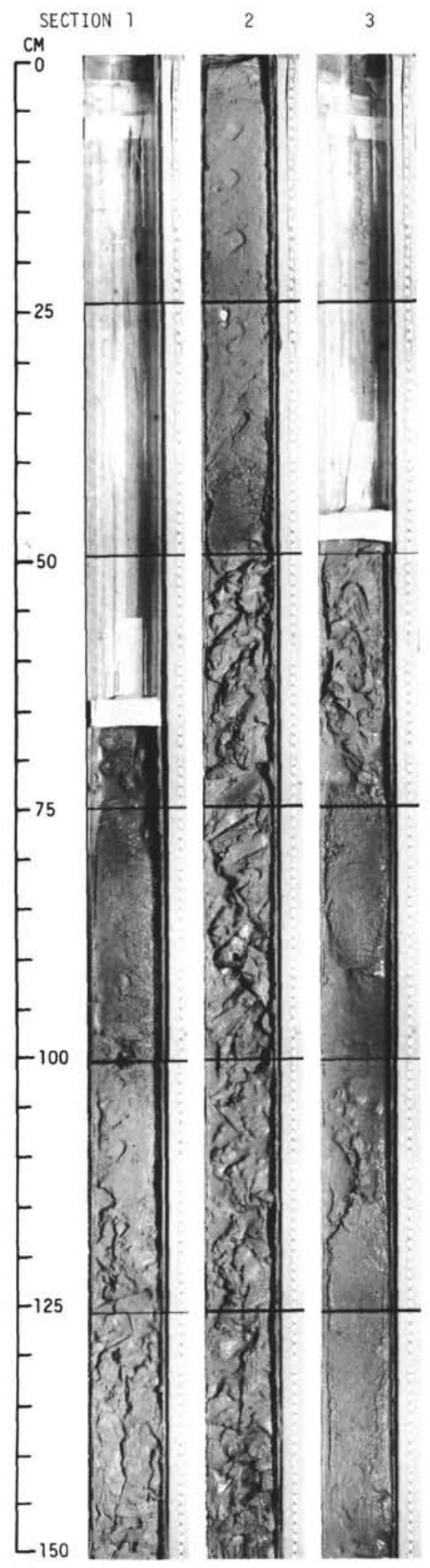




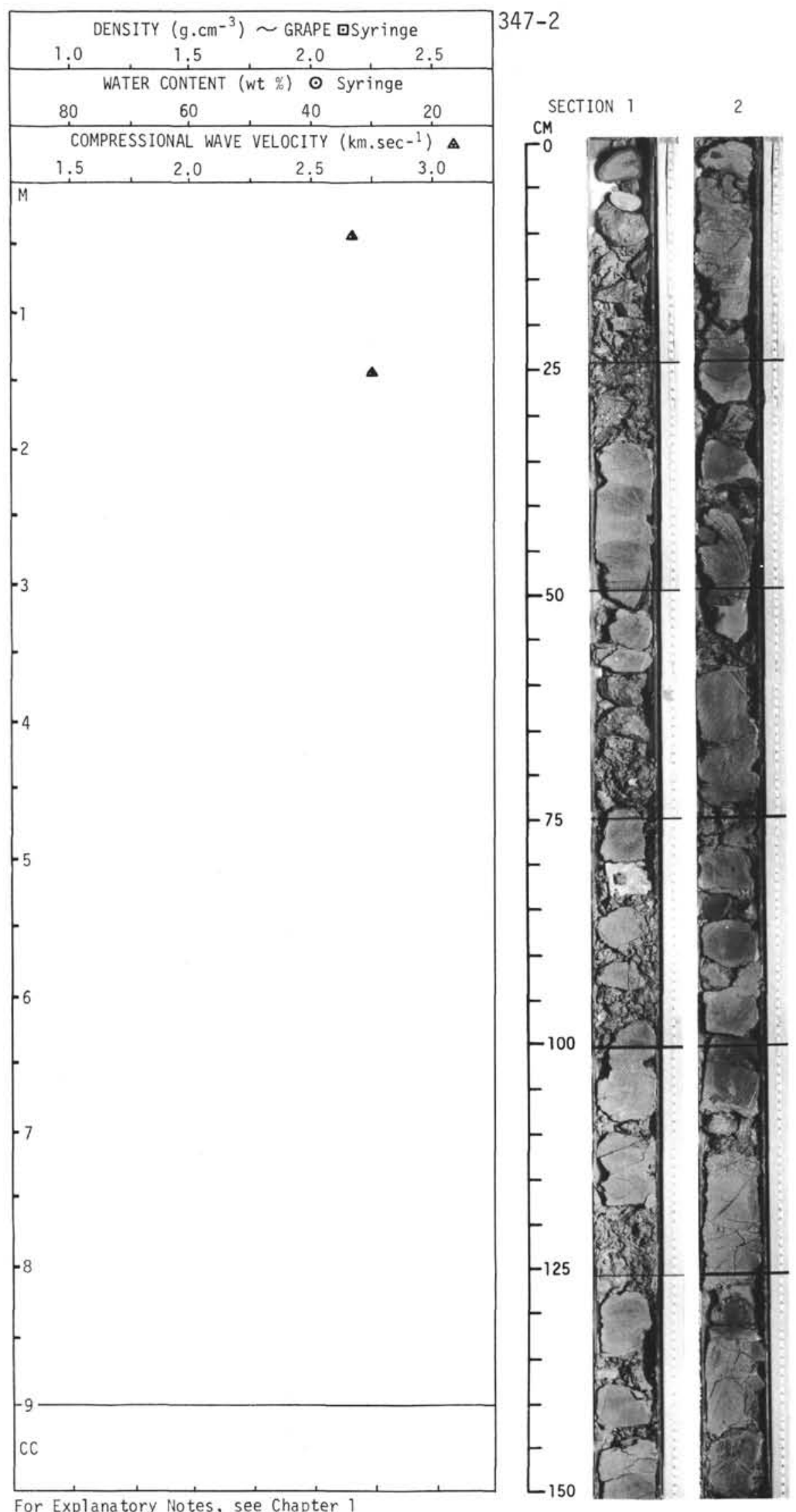




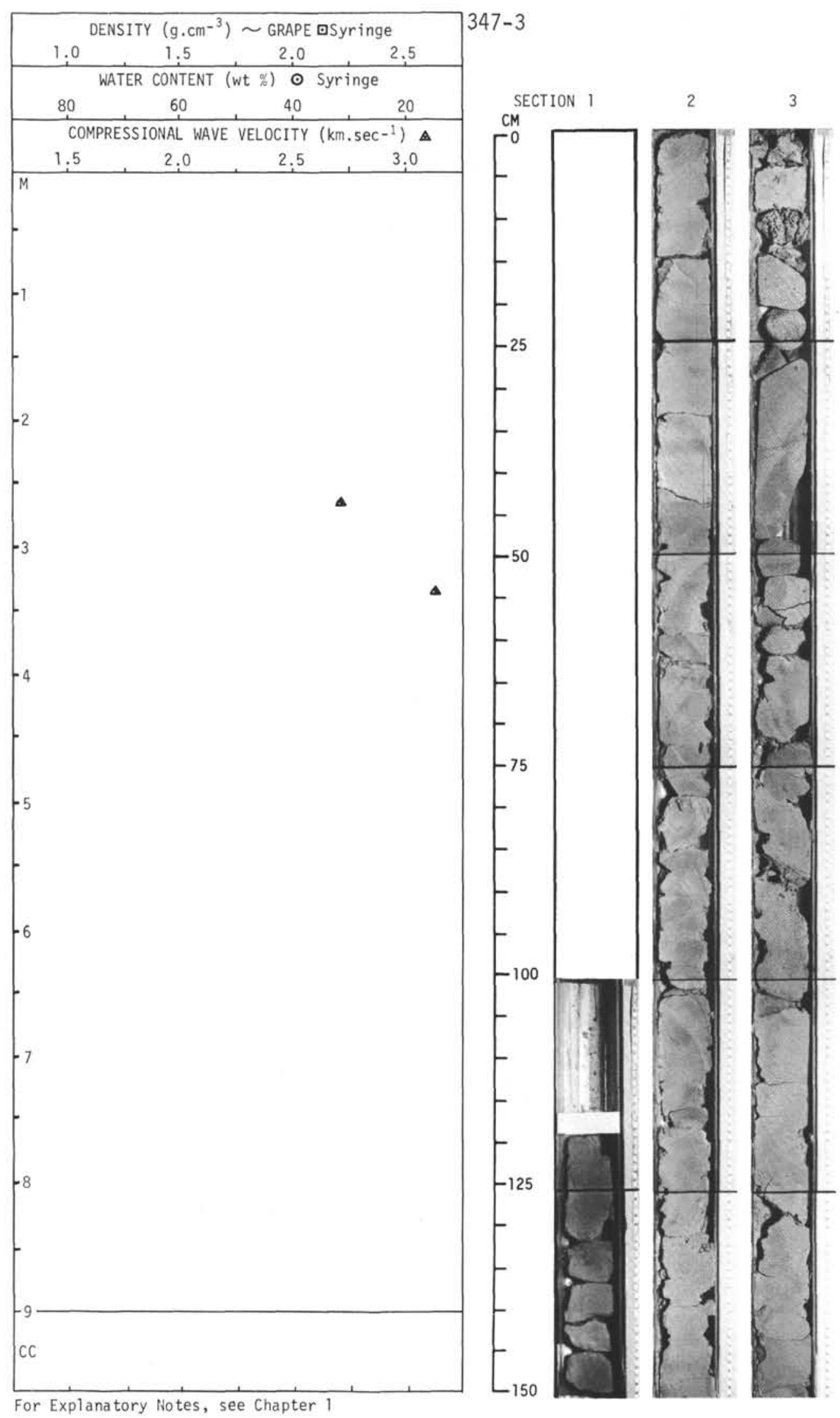




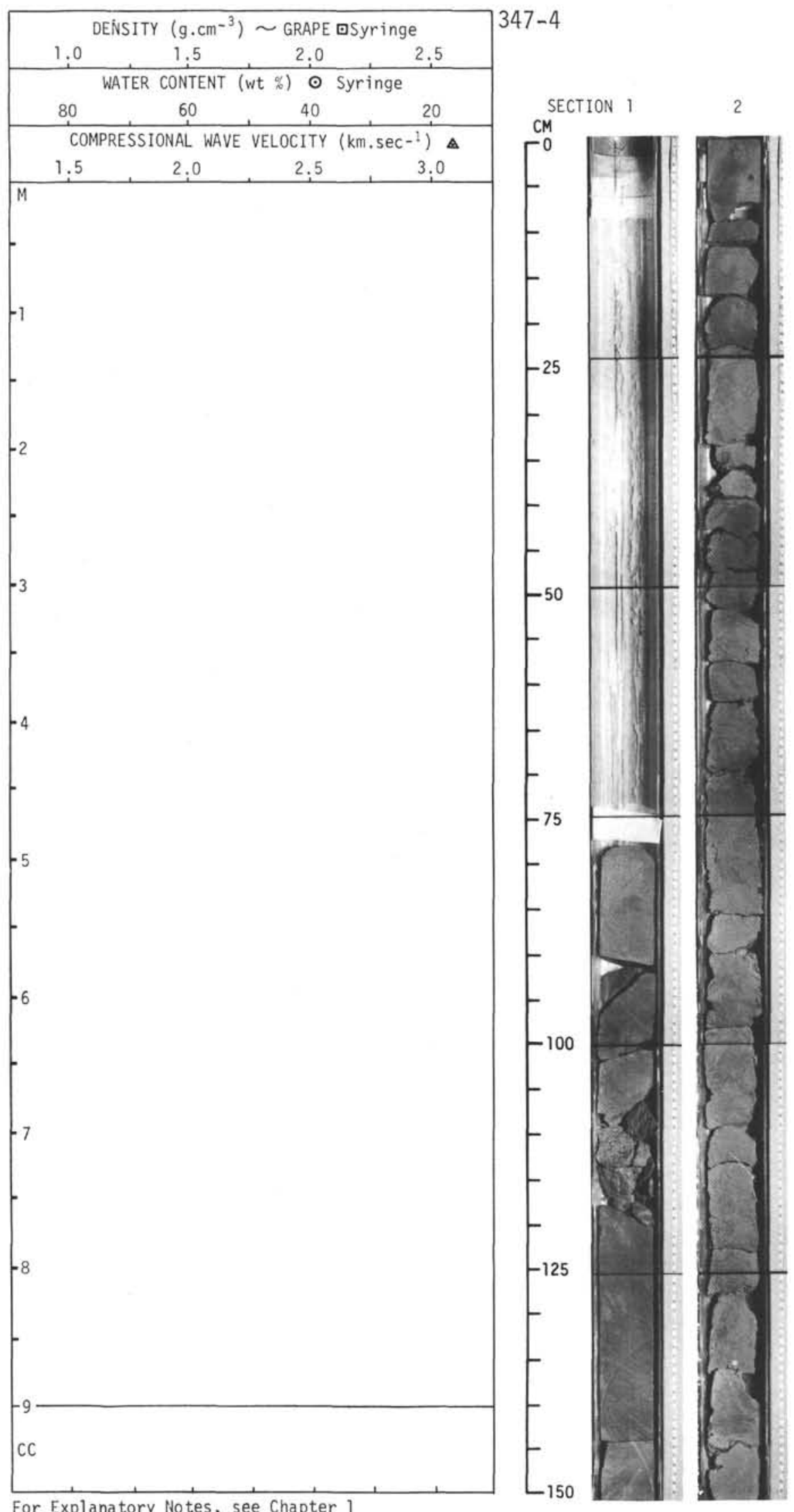



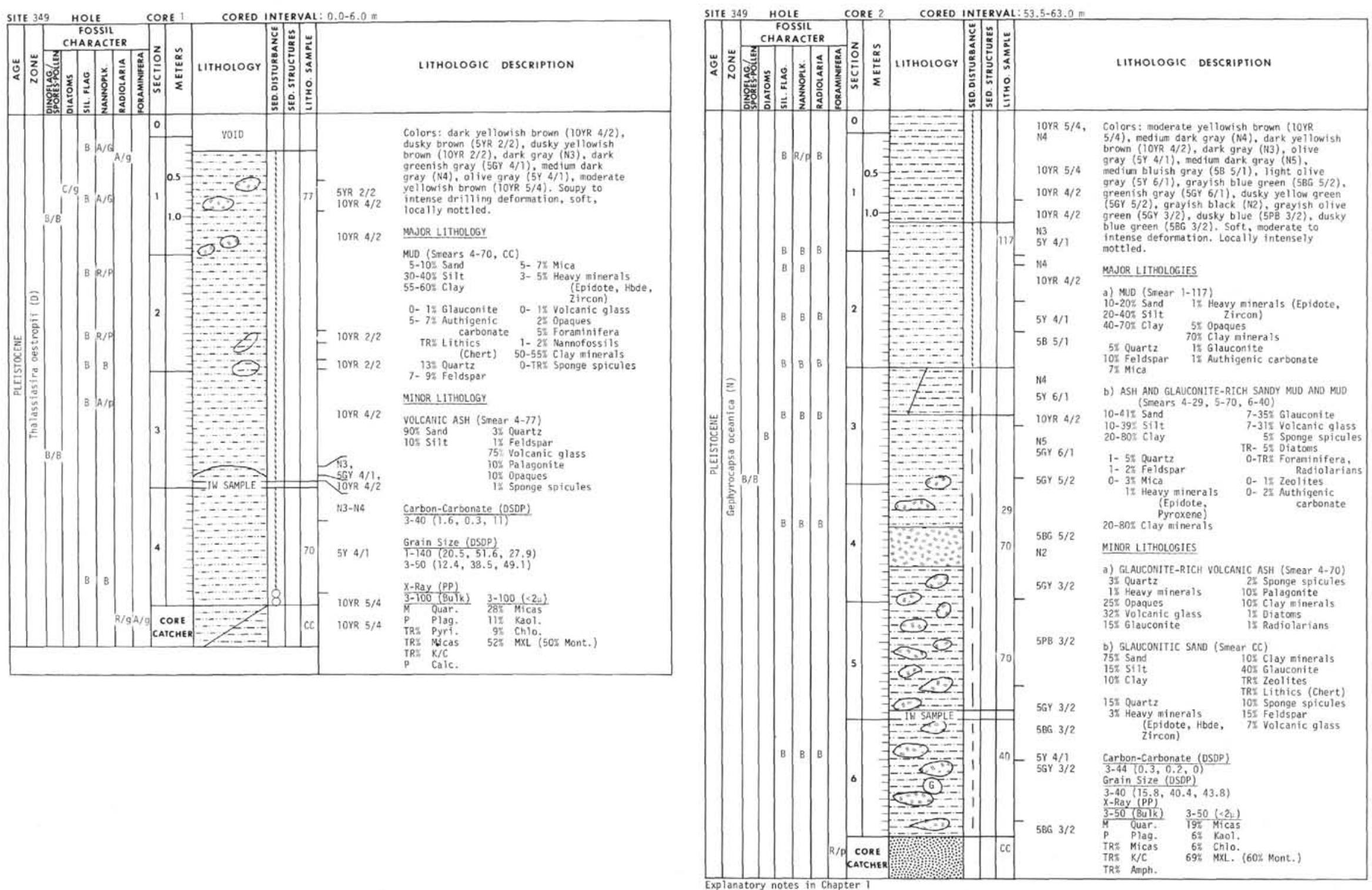


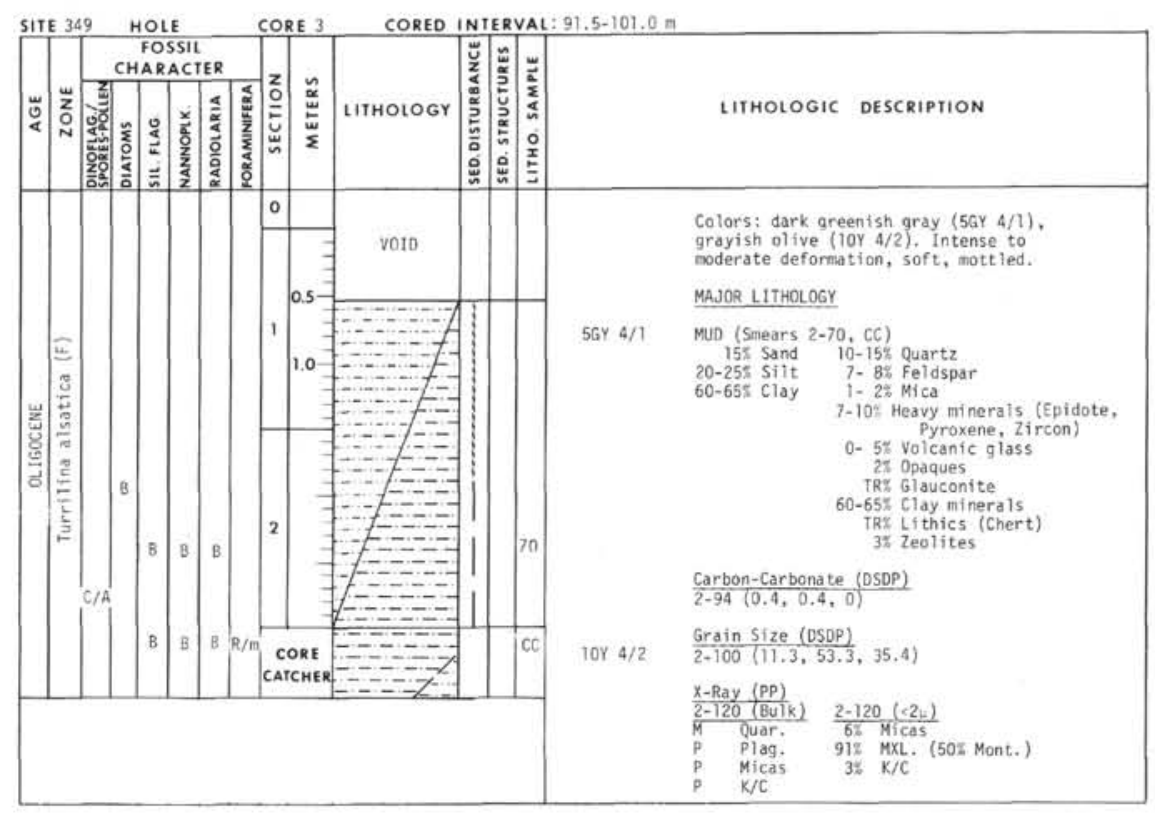

SIIE 349 HOLE CORE 4 CORED INIERVAL: 101,0-110.5 m

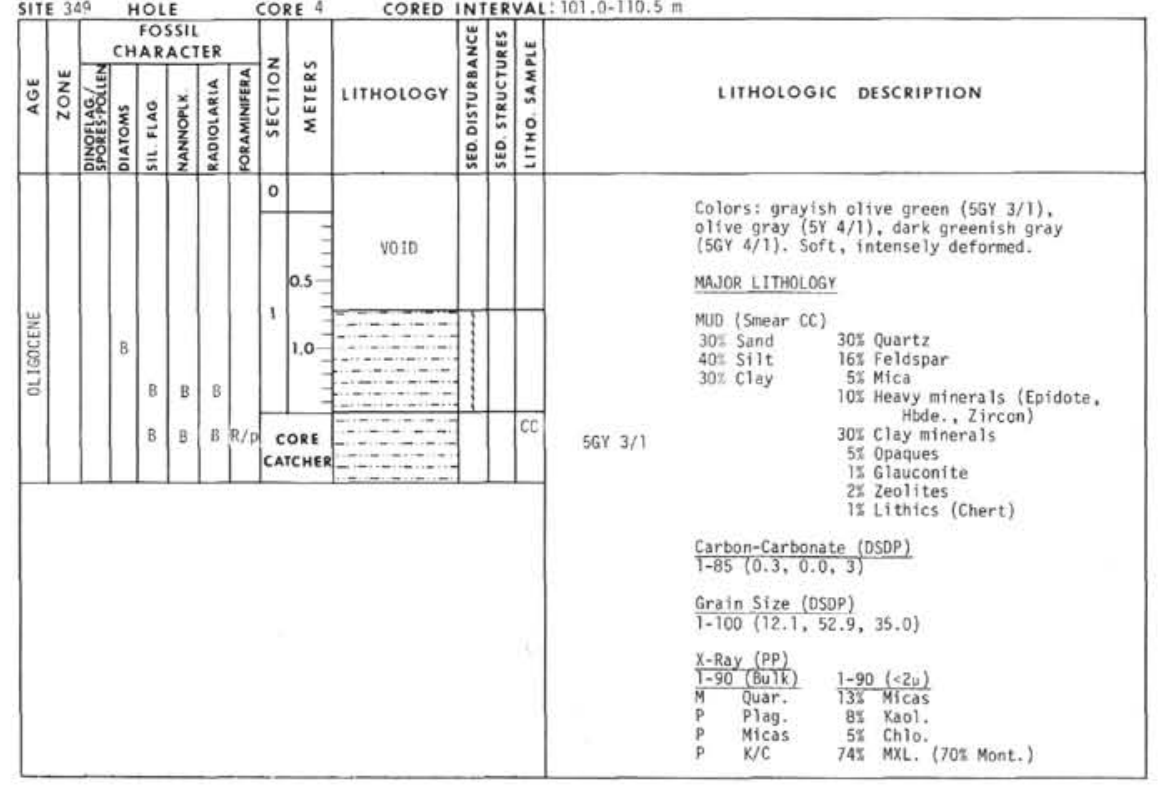

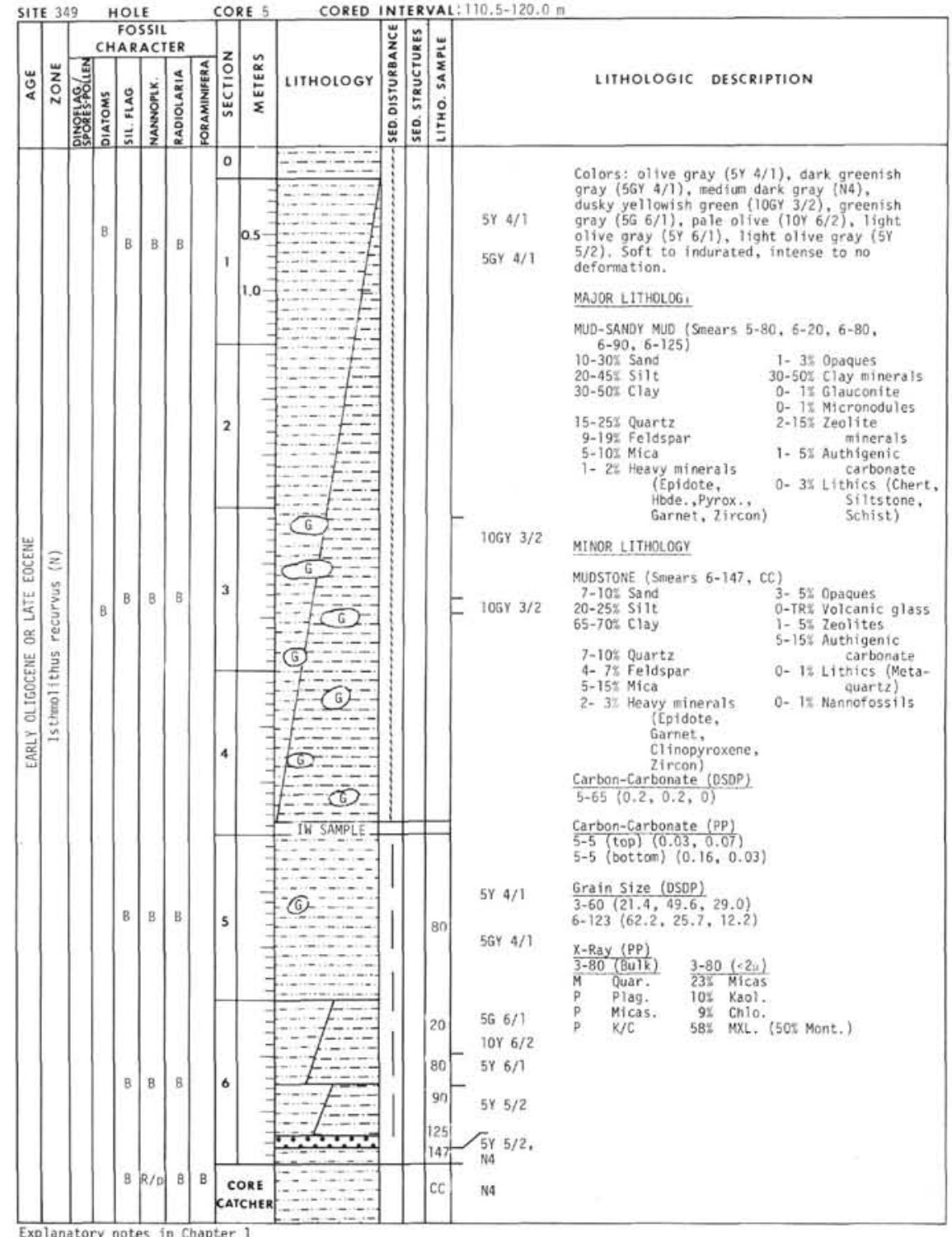

1 I 1 

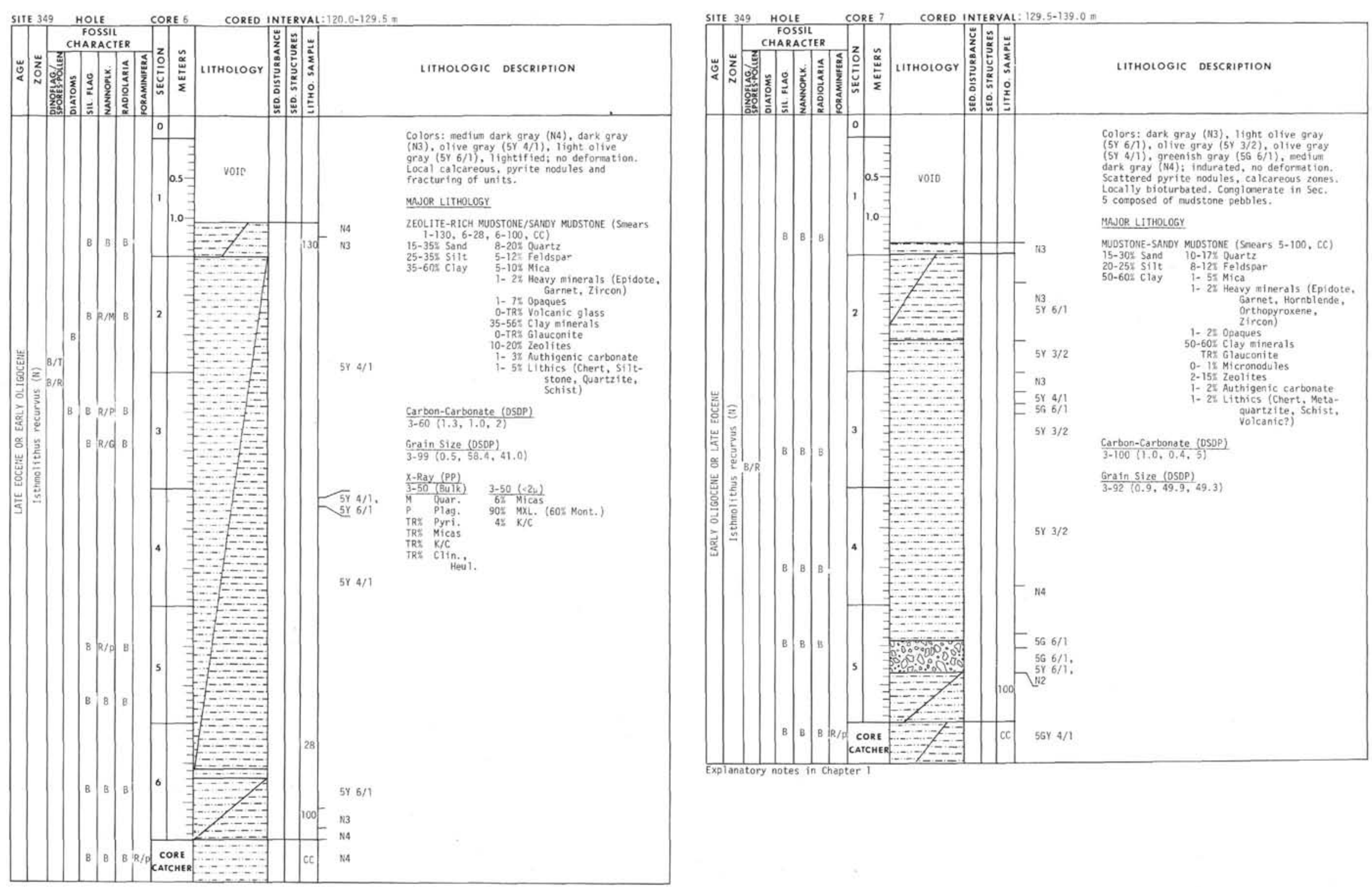


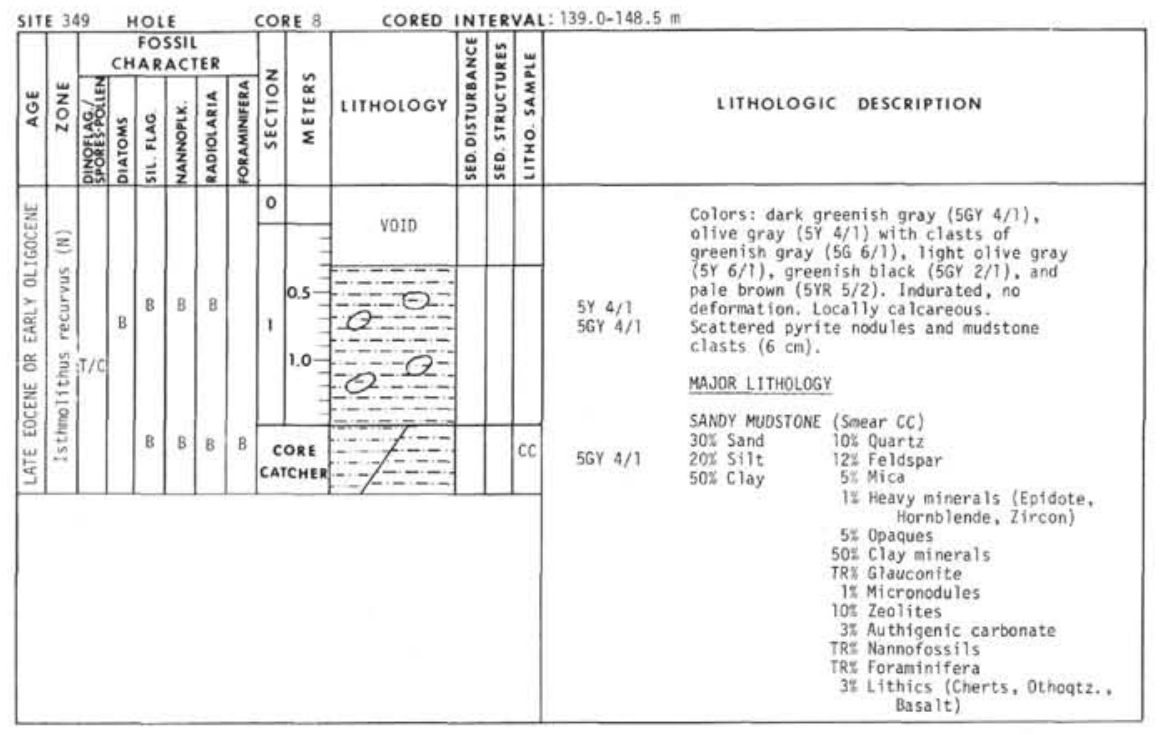

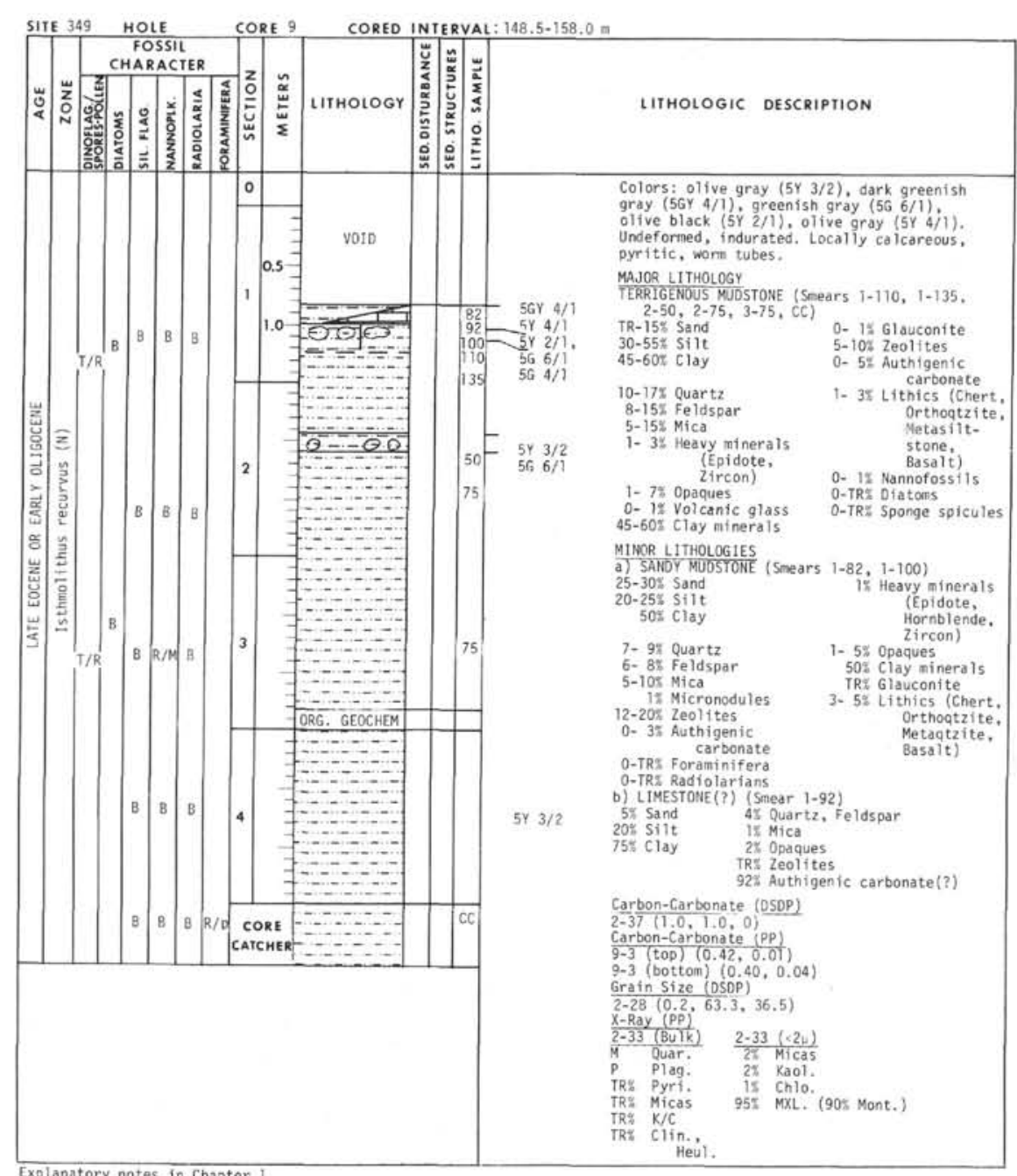

Explanatory notes in Chapter I 

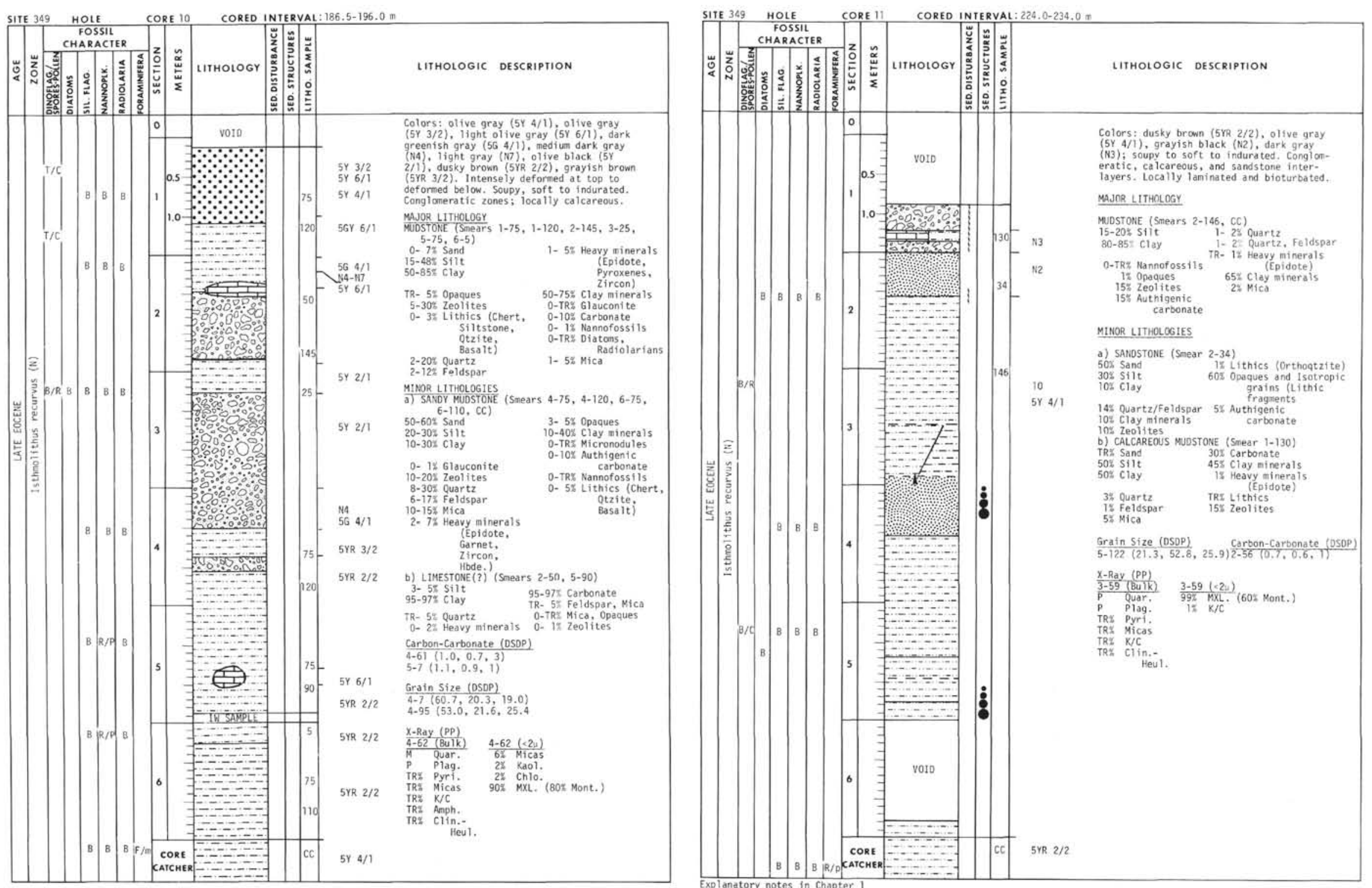

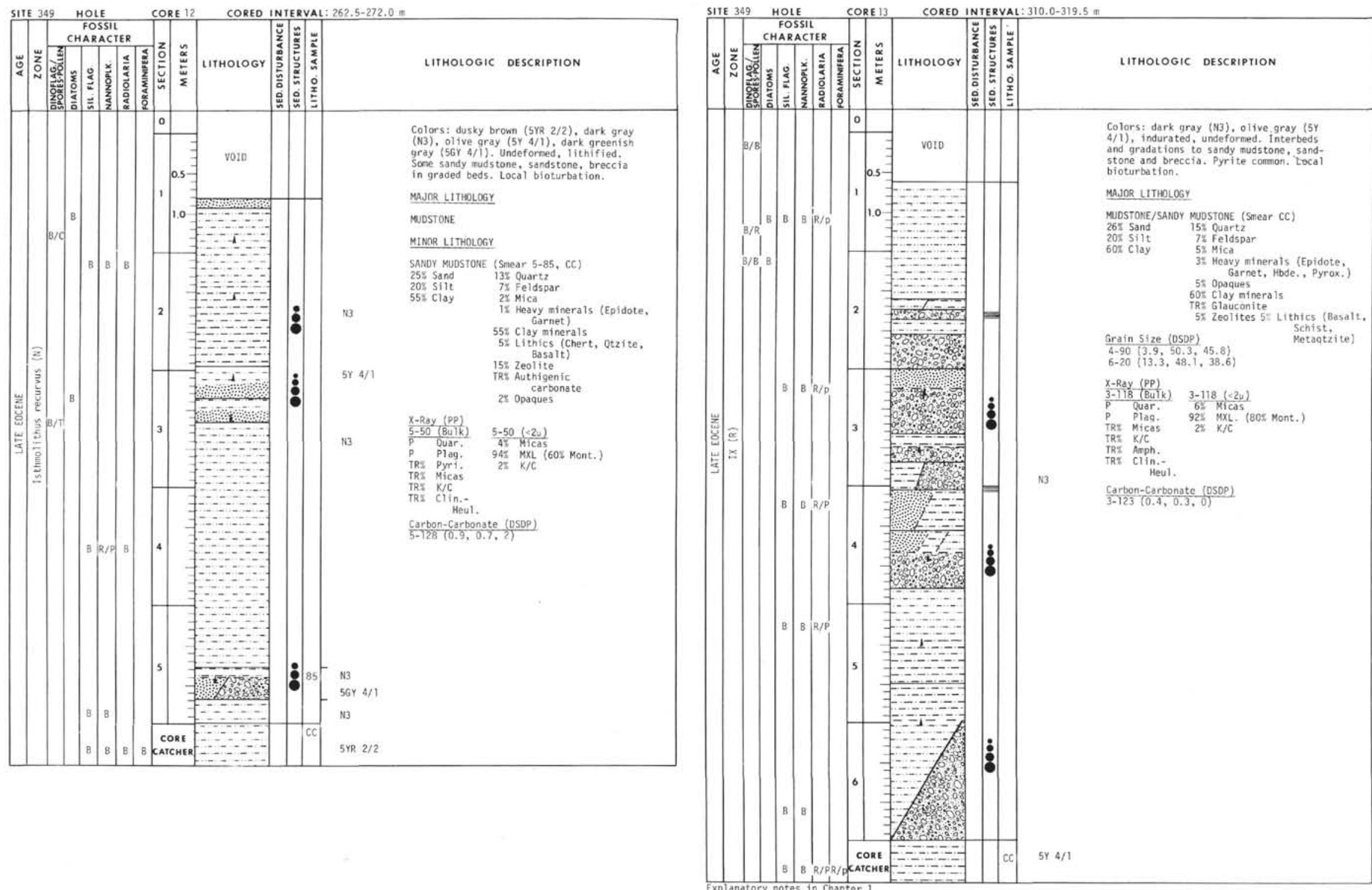


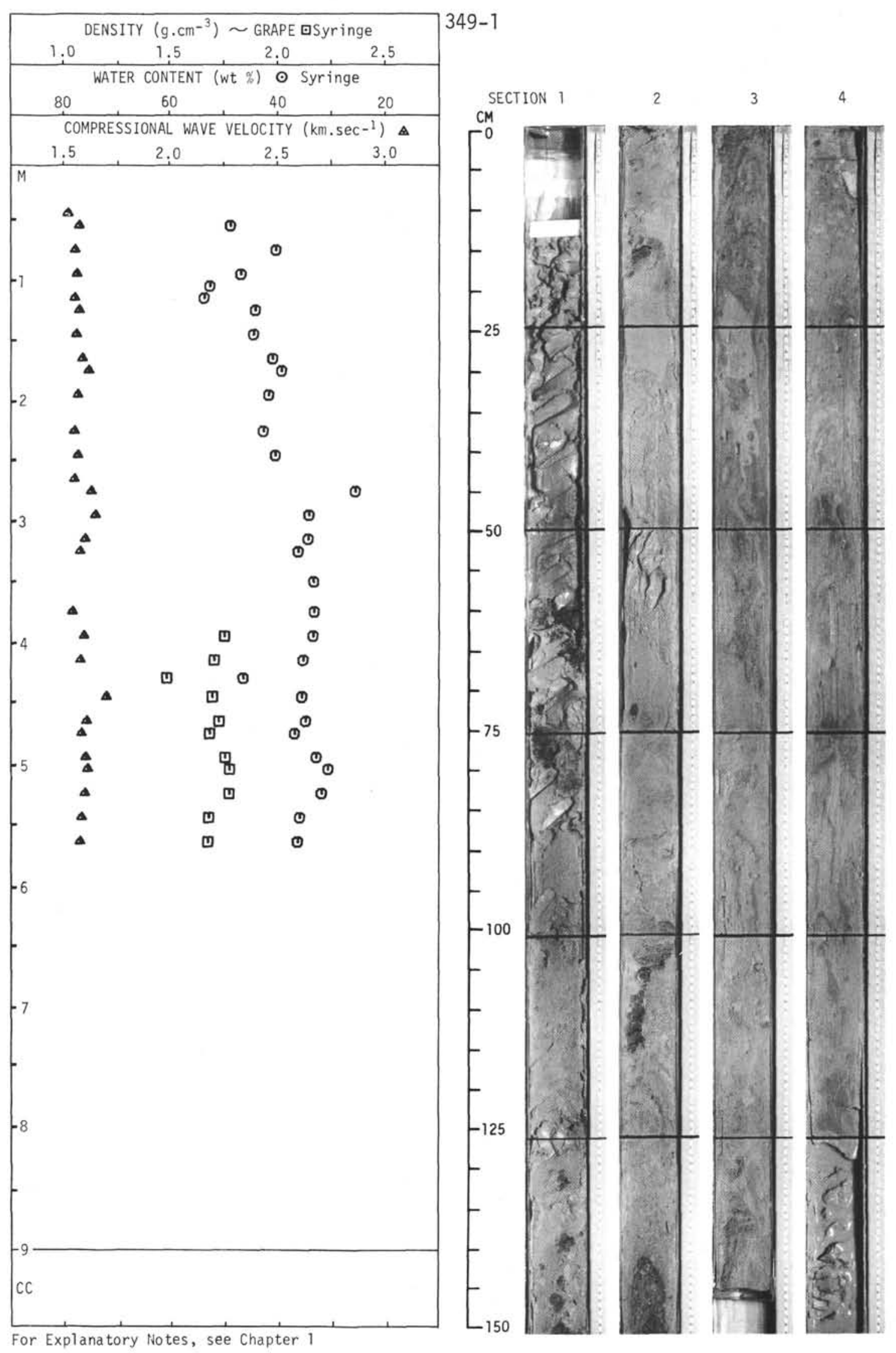




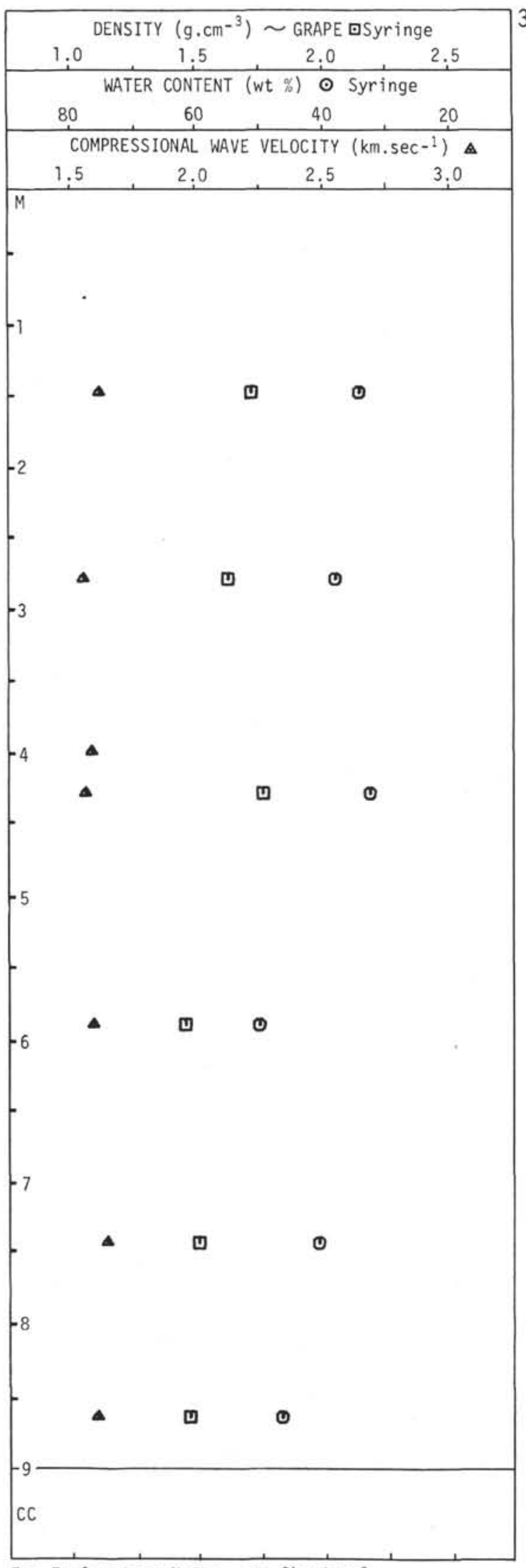

$349-2$

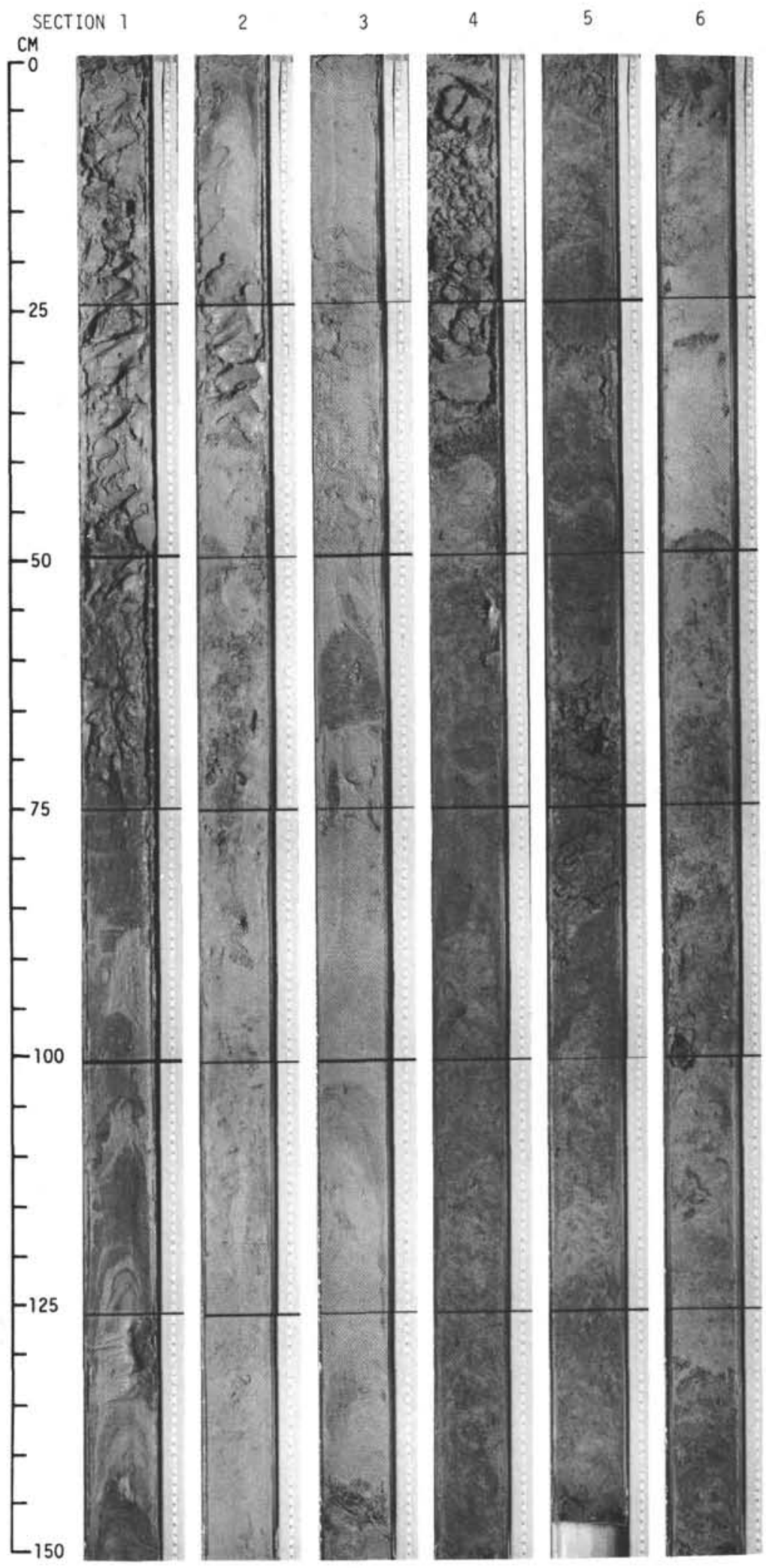




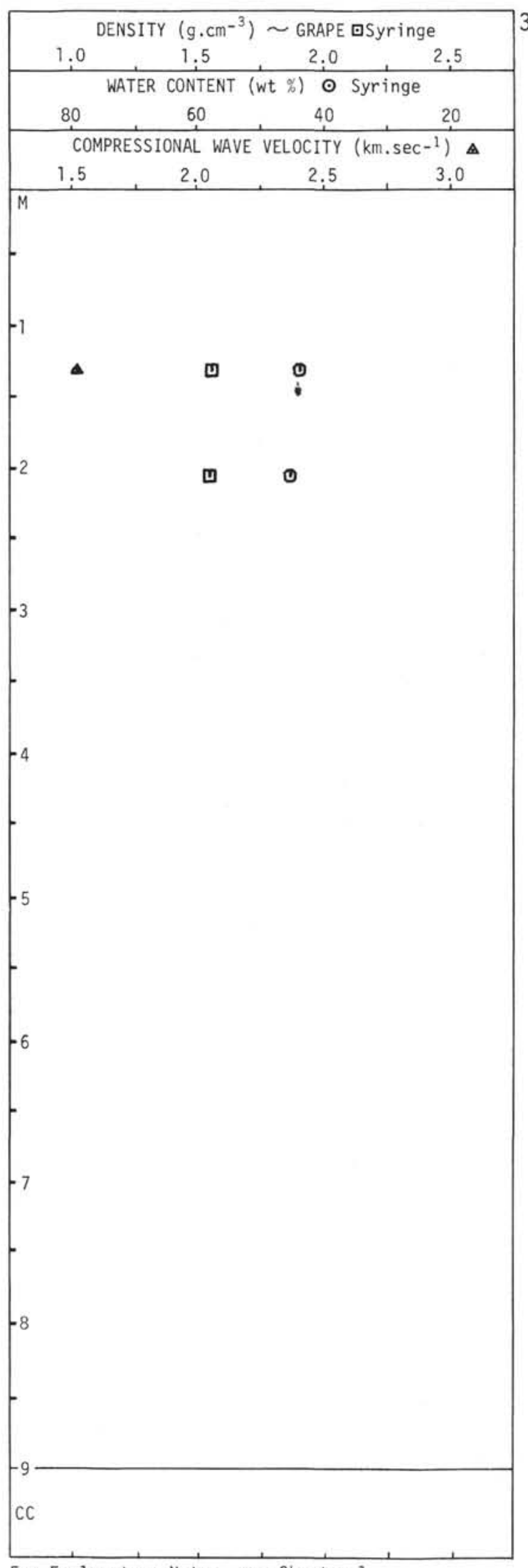

349-3

\begin{tabular}{|ccccc|}
\hline 1.0 & 1.5 & 2.0 & 2.5 \\
\hline & WATER CONTENT (wt \%) & $\odot$ & Syringe \\
80 & 60 & 40 & 20
\end{tabular}

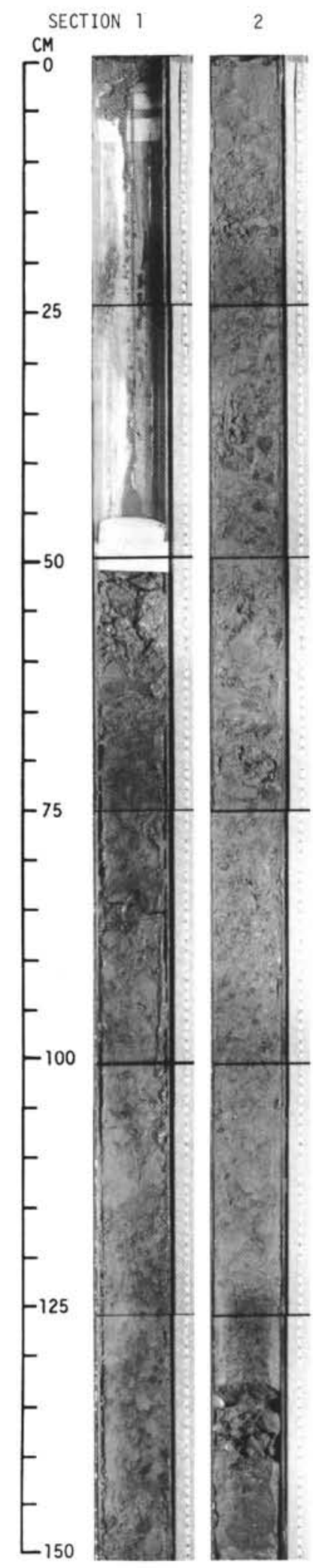

For Explanatory Notes, see Chapter 1 


$$
7
$$




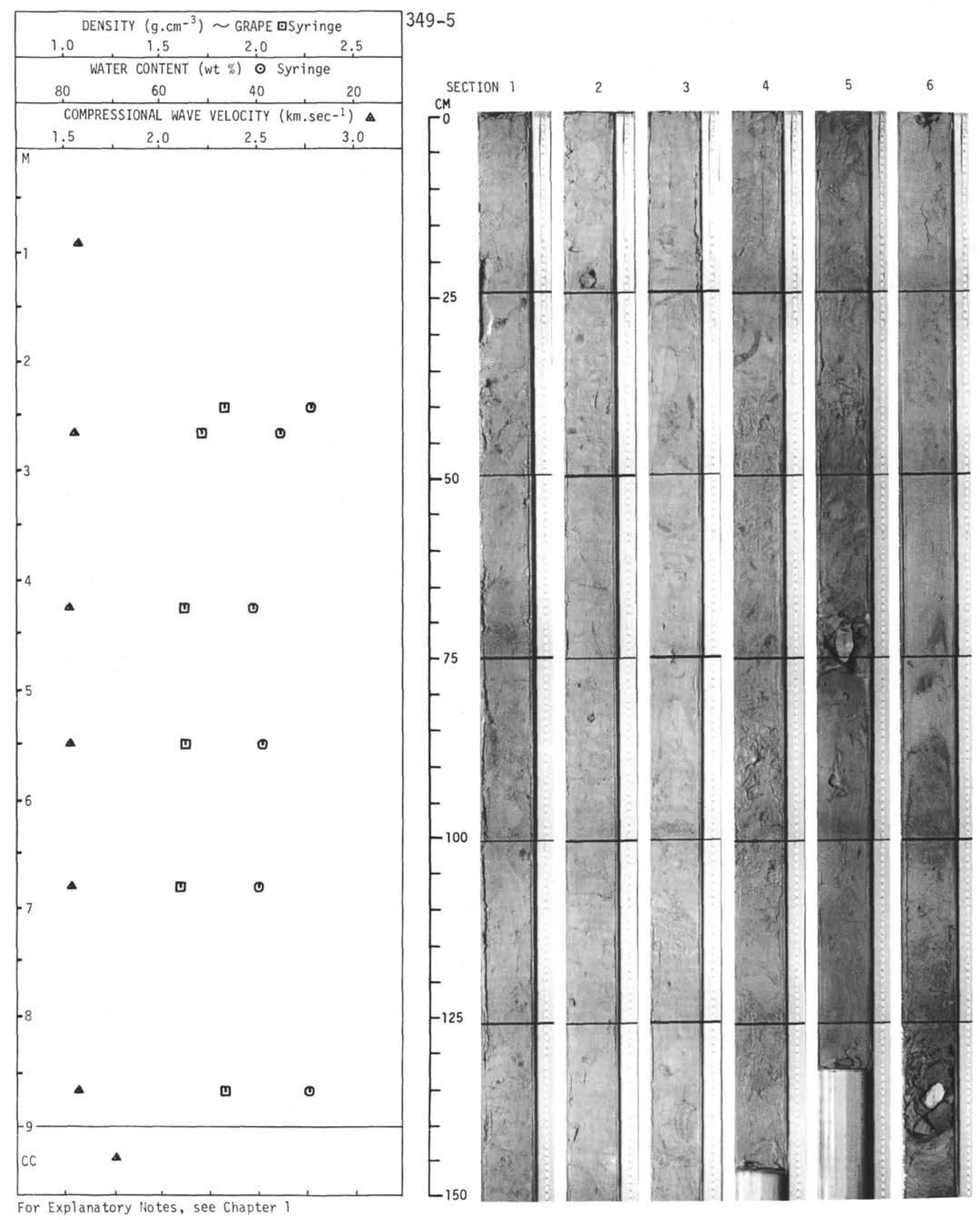




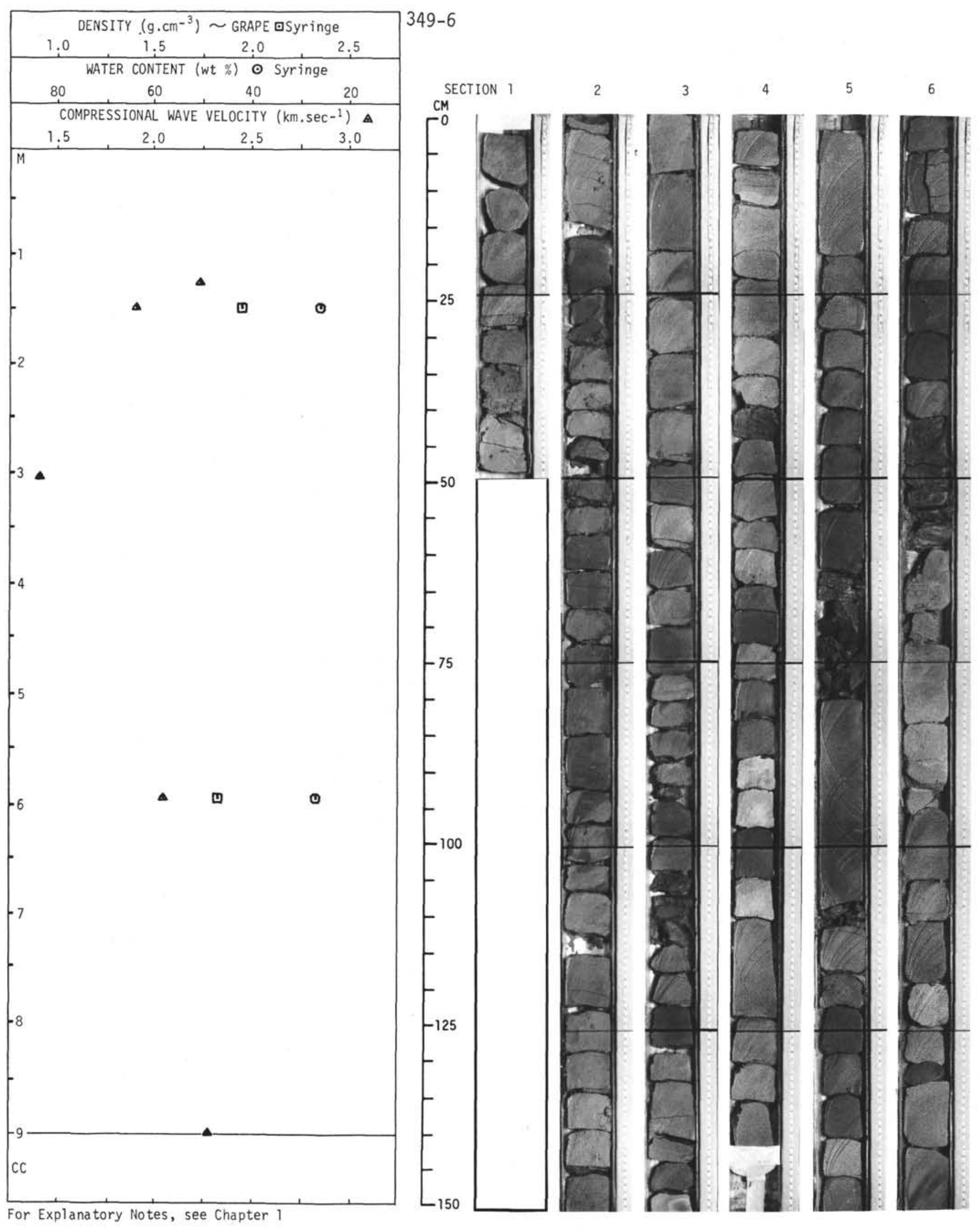




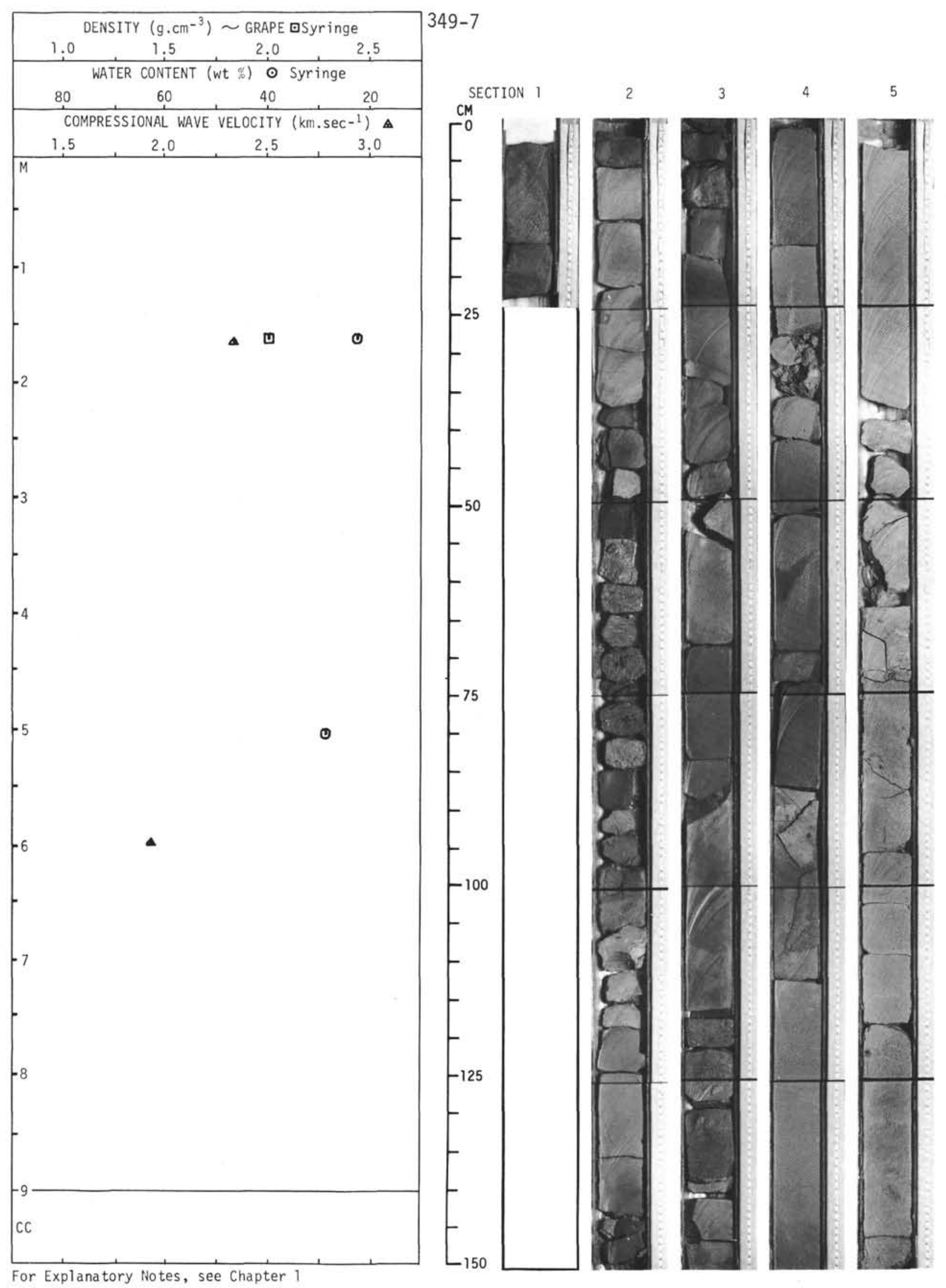




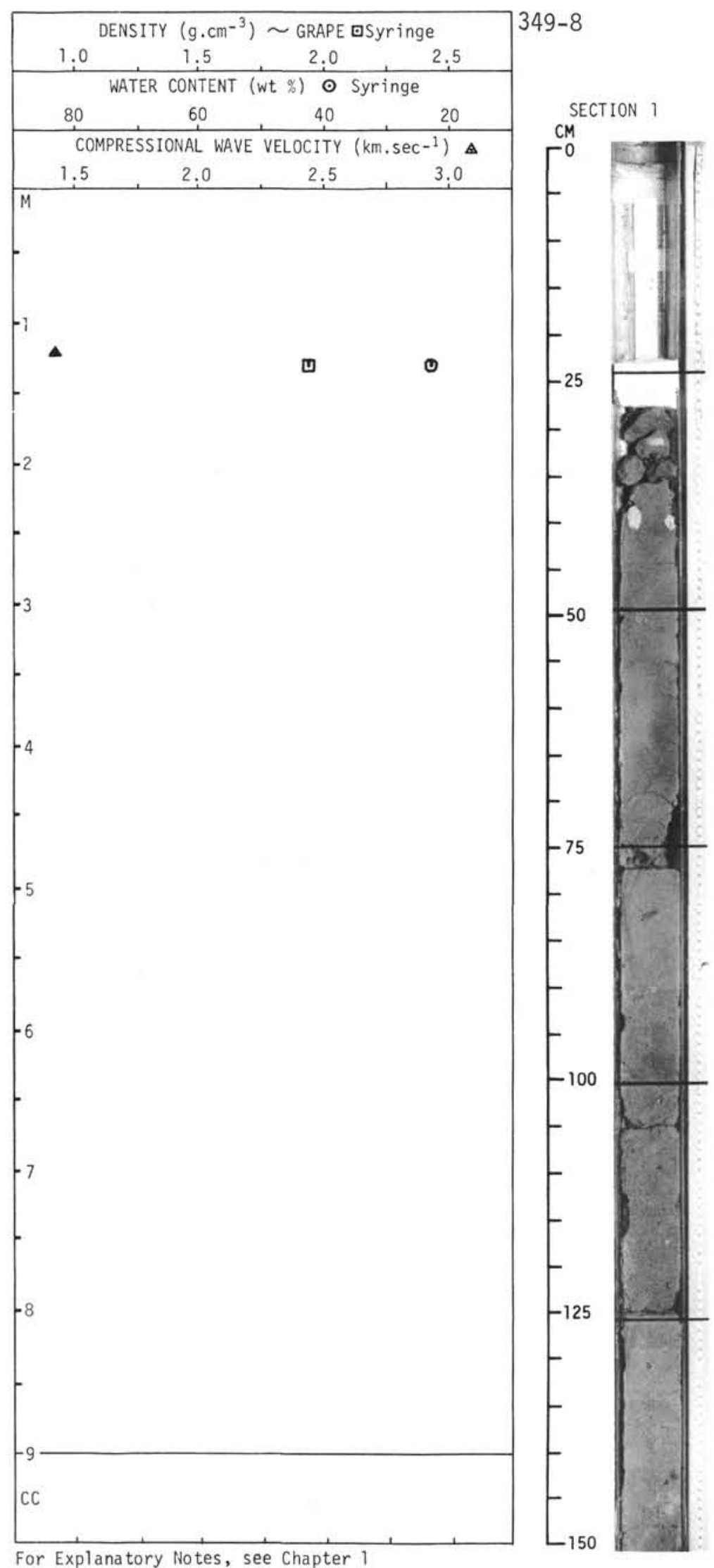




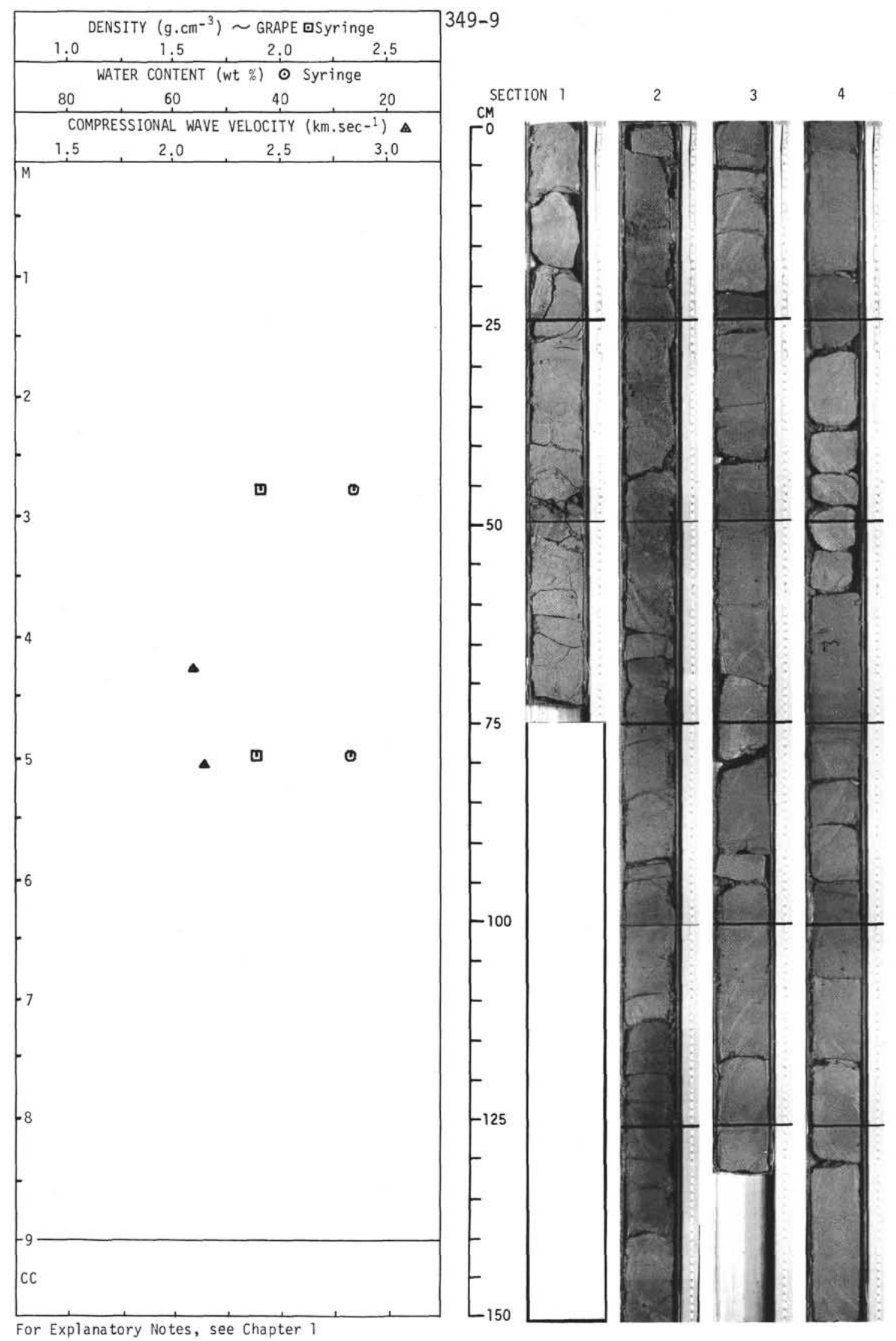




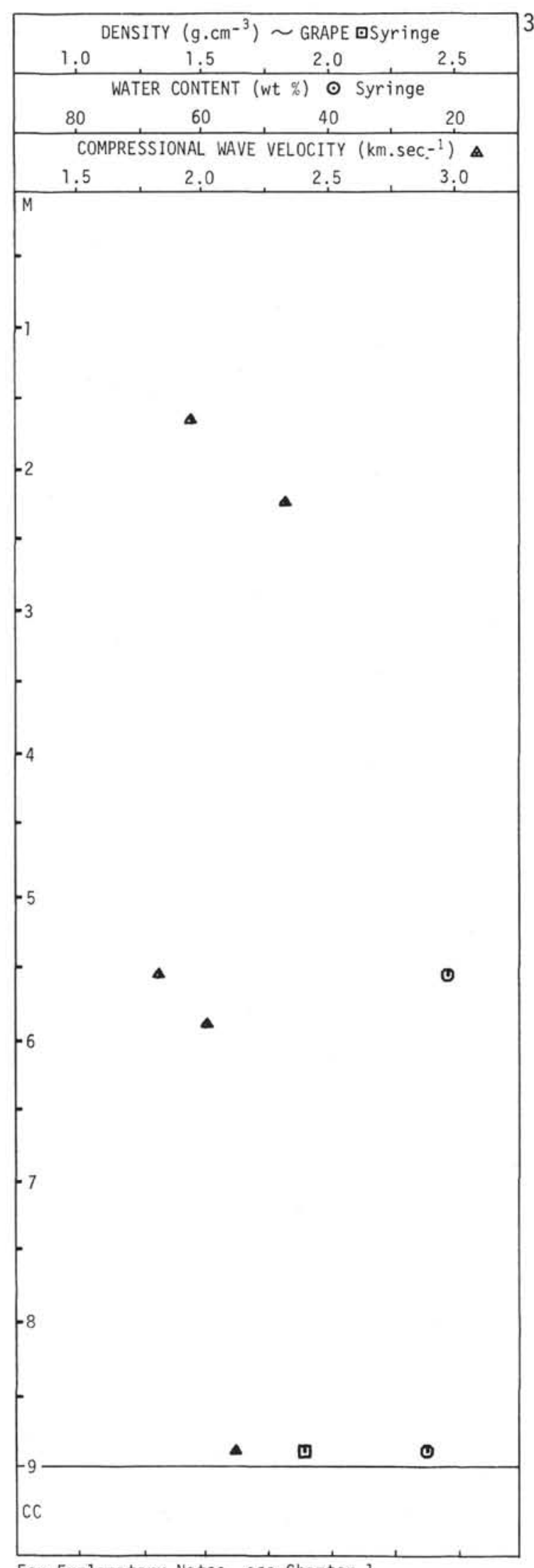

$349-10$

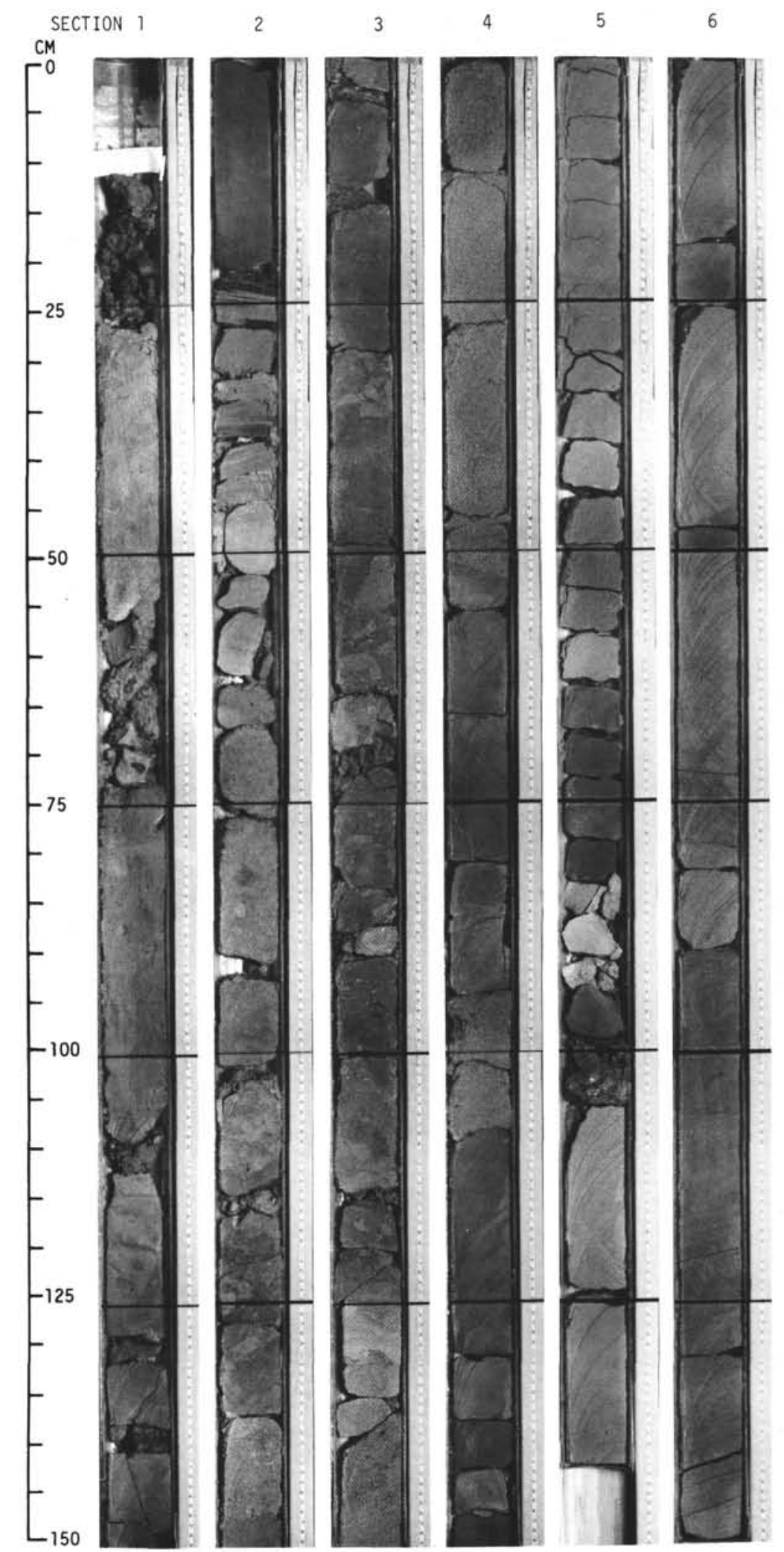




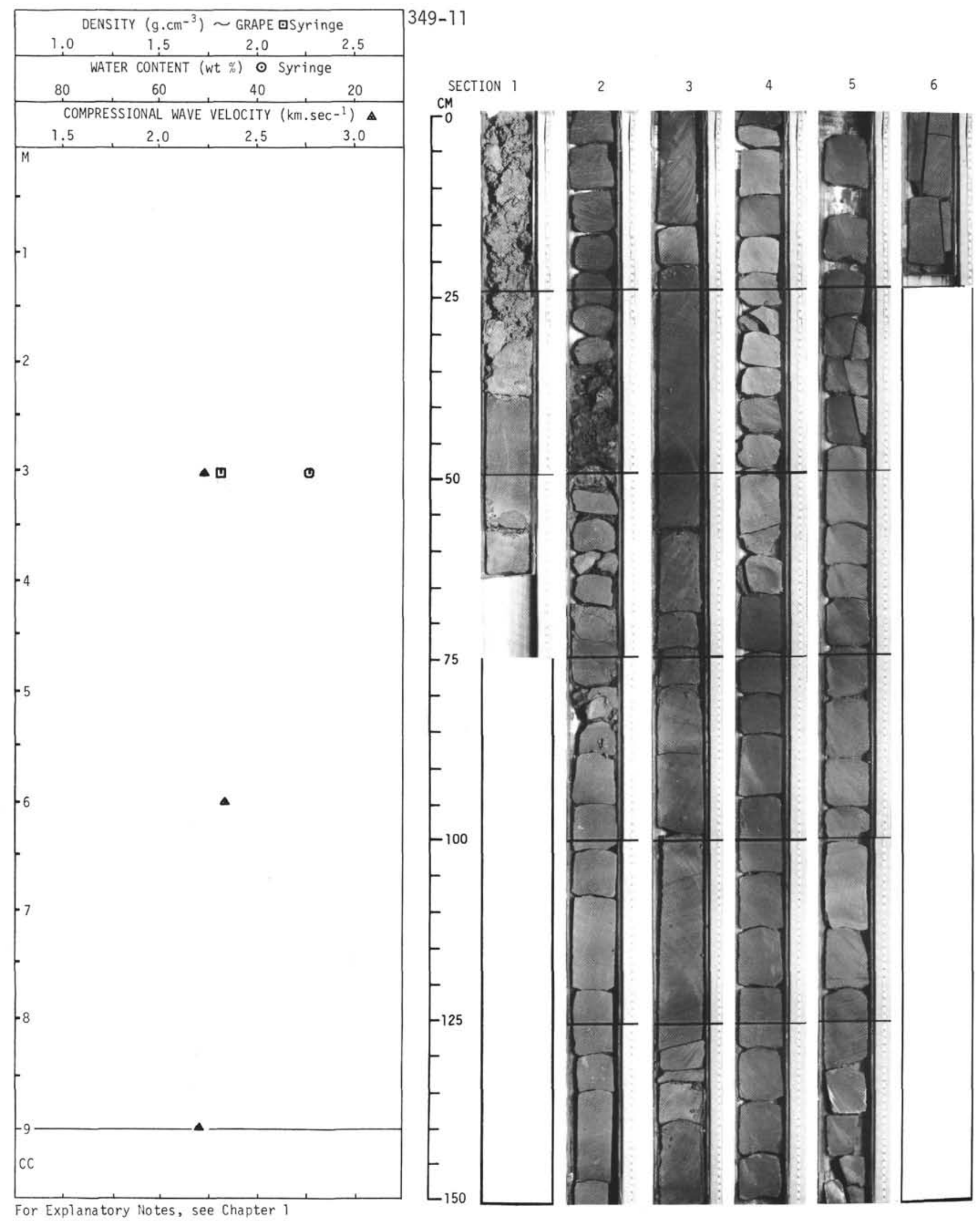




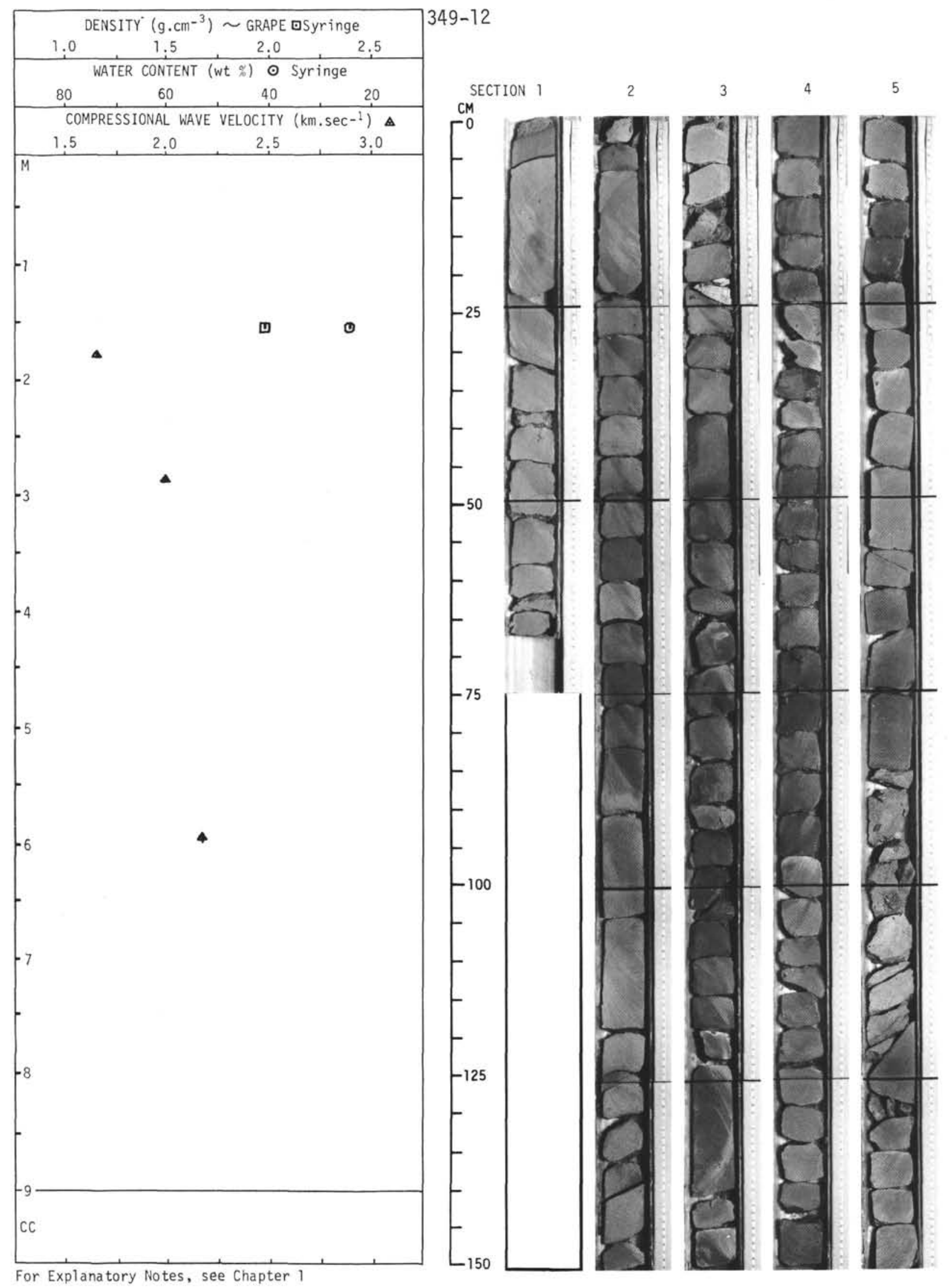




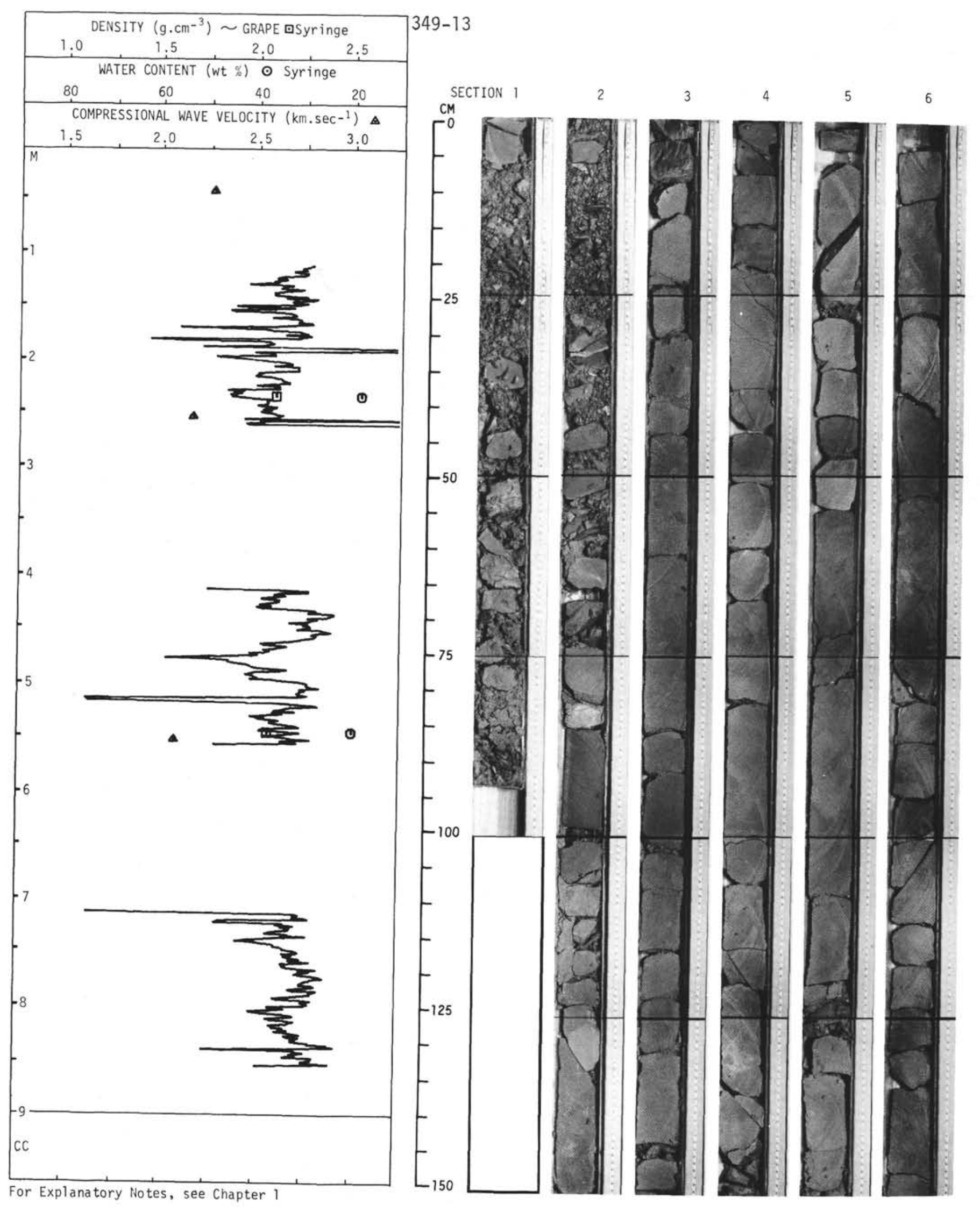

